Andrews University

Digital Commons @ Andrews University

Professional Dissertations DMin

Graduate Research

1980

\title{
TV-Radio Spot Evangelism: An Experiment in Attitude Change
}

James David Chase

Andrews University

Follow this and additional works at: https://digitalcommons.andrews.edu/dmin

Part of the Practical Theology Commons

\section{Recommended Citation}

Chase, James David, "TV-Radio Spot Evangelism: An Experiment in Attitude Change" (1980). Professional Dissertations DMin. 477.

https://dx.doi.org/10.32597/dmin/477

https://digitalcommons.andrews.edu/dmin/477

This Project Report is brought to you for free and open access by the Graduate Research at Digital Commons @ Andrews University. It has been accepted for inclusion in Professional Dissertations DMin by an authorized administrator of Digital Commons @ Andrews University. For more information, please contact repository@andrews.edu. 


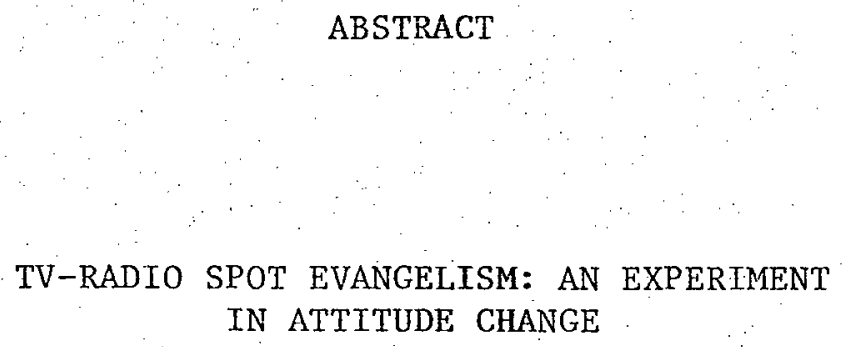

by

James David Chase

For the TV-Radio Spot Commission

General Conference of Seventh-day Adventists

January 1980 


\author{
ABSTRACT OF SURVEY RESEARCH \\ Andrews University \\ Theological Seminary
}

Title: TV-RADIO SPOT EVANGELISM: AN EXPERIMENT IN ATTTTUDE CHANGE

Name of researcher: James David Chase, D.Min.

Date completed: January 1980

Need

In its first meeting (April 23-24, 1979); the TV-Radio Spot

Commission voted to place on record its recognition of the need for a

Seventh-day Adventist Radio-TV Spot Ministry for the following reasons:

(1) Present media outreach tends to reach the church only, and polls reveal that the population has a very limited knowledge of the church and its mission.

(2) Image problems can only be solved by reaching a greater segment of the population than is being done at present through current programs.

(3) Spots can be used to augment the present church programming in radio/TV, and this is considered to be the next logical step in media outreach.

The objective of the TV-Radio Spot Commission, therefore, (as voted by the 1978 Annual Council), was "to study and design a radio and television spot campaign for the church." 


\section{Method}

The commission met three times: once in Washington D.C., and twice in Thousand Oaks, California.

The first two-day meeting resulted in substantial clarification of objectives for a TV-radio spot experiment, as well as specific plans for implementing the experiment itself. At this time, it was decided that--since attitude change precedes behavior change and since broadcasting is better at changing attitudes than behavior--the spot campaign should focus primarily on changing existing attitudes toward the people and the message of the Seventh-day Adventist Church.

The purpose of the second two-day meeting was to carefully review the sixty-five $\mathrm{TV}$ and radio spot scripts submitted to the comission for consideration. None of the scripts were selected for use, and the responsibility for planning and testing the spot approach was turned over to John Robertson and James David Chase.

A third meeting of available members of the T'V-Radio Spot. Commission met to review and approve the production of the spots. By this time, the city of Lubbock, Texas had been selected for the sight of the experiment, and preliminary research planning had taken place.

During the two week period of October 7-21, a carefully refined telephone pre-test was conducted in Lubbock involving eight specially trained local church members as interviewers. Over four thousand phone calls were made to find and survey 525 respondents having the necessary viewing and listening characteristics to be included in the survey frame: These individuals were not informed in any way that the Seventh-day Adventist Church was going to broadcast commercials, spots, or messages 
on radio or TV. They were simply told--as is a customary "panel design" practice--that they would be contacted again "in about a month to complete our study," with no reason given.

During the four week period of October 22-November 16, three TV stations and seven radio stations aired the same two spots daily in fringe-prime time $(5: 30-7: 00 \mathrm{p} . \mathrm{m}$. on TV), and prime time $(7: 00-9000$ a.m. on radio). In addition, many of both the radio and TV stations aired the spots free as a public service at various times during the broadcast day. These spots used the personal testimony format involving (1) a man whose wife had died unexpectedly and his comments concerning belief in the Bible promise of the second coming of Jesus Christ and the hope of the resurrection, and (2) a blind Iady demonstrating her unique abilities, expressing a positive attitude toward life in spite of her handicap. Both spots were tagged: "A message from the Seventh-day Adventists."

In the week of November $18-21$, a post-test survey was conducted. During this time, every effort was made to contact and re-survey all 525 persons originaliy included in the pre-test (a number substantially more than that required to be statistically significant at the 95 percent level of survey reliability). Of these, 456 persons (still substantially more than required) were contacted and re-surveyed, using a carefully constructed, "branching" survey instrument to ascertain, particularly, what changes in attitude toward the Adventist Church may have occured in the respondents as a result of being exposed to the spots. 


\section{Results}

The statistically significant results (.05 level) were astounding. Whereas before the spots were aired in Lubbock, Texas only 17. percent of those interviewed had a positive attitude toward Adventists, after the spots almost half--47 percent--of those interviewed had a positive attitude toward Adventists--a 30 percent increase.

The largest increase in positive attitudes occured among females in their $20^{\prime} \mathrm{s}$, (who also constituted the largest number of respondents in the survey: 16.66 percent). In this group, whereas before the spots only 7 percent of them had a positive attitude toward Adventists, after the spots were aired over half of them-51 percent--expressed a positive attitude toward Adventists--a 44 percent increase.

Similarly, before the spots were aired 16 percent of all those interviewed had a negative attitude toward Adventists. But after the spots were aired, only 6 percent of those interviewed had a negative attitude toward Adventists--a decrease of 10 percent.

The largest decrease in negative attitudes occured among those in their 40's. In this case, whereas almost a third--31 percent--of the respondents had a negative attitude toward Adventists before the spots, only 6 percent of them had a negative attitude toward Adventists after the spots--a 25 percent decrease in negative attitudes. .

In addition, 93 percent of those interviewed remembered seeing or hearing the spots. Of these, 70 percent initially remembered the spots as being associated with Seventh-day Adventists. 23 percent more remembered having seen or heard the spots when their content was briefly described. 
There were 35 percent of those interviewed who said they would be more inclined-- now than before being exposed to the spots-to know more about Seventh-day Adventists.

And 43 percent of those interviewed said they would be more inclined--now than before being exposed to the spots--to attend meetings sponsored by Seventh-day Adventists.

\section{Conclusions}

The study appears to show conclusively that the TV-radio spot approach using a personal testimony format does change attitudes substantially.

It is further noted that--since positive attitude change toward an organization generally precedes positive behavior change toward or positive response to that organization--the TV-radio spot approach appears to be the logical first and necessary step in any carefully constructed evangelistic strategy for the church. 

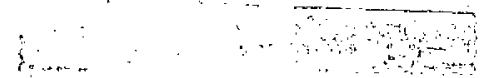

ABSTRACT

RADIO SPOT EVANGELISM: THE DEVELOPNENT OF A RESEARCH-BASED RADIO SPOT SERIES

FOR NOMINAL AND NON-CHRISTIANS

by

James David Chase

Chairperson: Steven P. Vitrano 


\title{
ABSTRACT OF GRADUATE STUDENT RESEARCH \\ PROJECT REPORT
}

\author{
Andrews University
}

Theological Seminary

Title: RADIO SPOT EVANGELISM: THE DEVELOPMENT OF A RESEARCH-BASED

RADIO SPOT SERIES FOR NOMTNAL AND NON-CHRISTIANS

Name of researcher: James David Chase

Name and title of chairperson: Steven P. Vitrano, Ph.D.

Date completed: July 1977

\section{Problem}

Although marketing and advertising firms spend millions of dollars annually to determine which types of commerical radio spots are most effective in appealing to specific audiences, 1ittle of this research has been done by churches using the broadcast media. The objective of this project, therefore, was to discover which of the most commonly used radio production formats contribute most to credibility and acceptability of religious radio spots whose intended audience is either nominal or non-Christian and to produce a thirteen-week series of daily public service radio spots for evangelistic purposes based on this determination. 


\section{Method}

A telephone survey of 724 persons in the Benton HarborSt. Joseph, Michigan, area was used to isolate and survey 311 nominal and non-Christians. The survey was conducted during the period of December 1976 to February 1977.

Prior to the survey, 386 on-the-street interviews were conducted by the researcher in the survey area to refine and eliminate as much bias as possible from the survey instrument. In addition, twenty-one Andrews University faculty members (whose research opinions were considered significant to this study) were sent copies of a preliminary draft of the survey instrument which sought their advice and counsel.

\section{Results}

The most acceptable type of radio spot for most nominal and non-Christians was found to include (1) the use of music, (2) "someone telling a personal experience he has had," and (3), when Christianity is presented, "any Christian telling why he is one."

The most credible type of radio spot for most nominal and non-Christians was found to have the same characteristics as the most acceptable type, but with one exception. There was no clearcut opinion regarding whether or not the use of music in a radio spot affects its credibility.

\section{Conclusions}

It was concluded that four commonly used radio production formats studied do contribute to credibility and acceptability of radio spots for nomina1 and non-Christians. 
On the basis of these findings and related research, a thirteen-week series of "persona1 experience," daily radio spots was produced for evangelistic purposes. The series was produced using the facilities of WAUS-FM, the Andrews University radio station. 


\title{
Andrews University
}

Seventh-day Adventist Theological Seminary

RADIO SPOT EVANGELISM: THE DEVELOPMENT OF A RESEARCH-BASED RADIO SPOT SERIES

FOR NOMINAL AND NON-CHRISTIANS

\author{
A Project Report \\ Presented in Partial Fulfillment \\ of the Requirements for the Degree \\ Doctor of Ministry
}

by

James David Chase

June 1977 



\title{
RADIO SPOT EVANGELISM: THE DEVELOPMENT OF A RESEARCH-BASED RADIO SPOT SERIES \\ FOR NOMINAL AND NON-CHRISTIANS
}

\author{
A project report \\ presented in partial fulfillment \\ of the requirements for the degree \\ Doctor of Ministry
}

by

James David Chase

APPROVAL BY THE COMMTTEE:

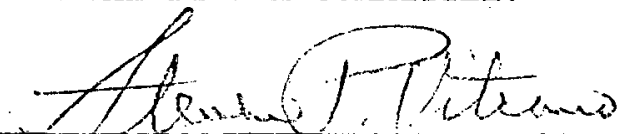
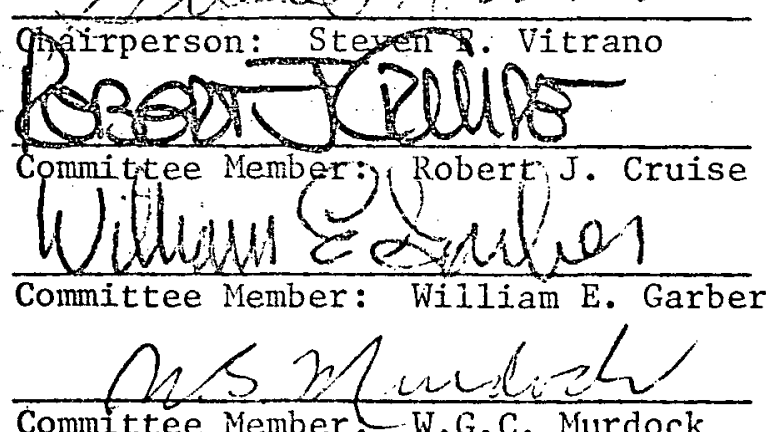

Committee Member?.W.G.C. Murdock

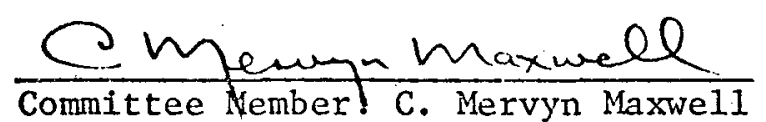

July 7, 1977

Date approved

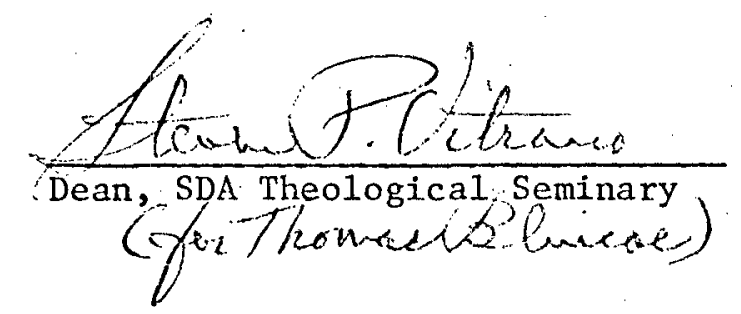


TABLES OF CONTENTS

LIST OF TABLES . . . . . . . . . . . . . . . . xiii

ACKNOWLEDGMENTS . . . . . . . . . . . . . . . . xvi

Chapter

I. INTRODUCTION: AN OVERVIEW OF THE PROJECT . . . . . . . 1

The Objective of the Project . . . . . . . . . 1

Justification of the Project . . . . . . . . . . 1

Description of the Project............. 2

II. A THEOLOGICAL BASIS FOR MASS MEDIA EVANGELISM . . . . 5

The Need for a Biblical Understanding of

Mass Media Evangelism . . . . . . . . . . 5

A Biblical Precedent for Mass Media Evangelism . . . . 5

Incarnation: The Essence of Divine Communication... . 9

Incarnation: The Ideal of Christian

Communication . . . . . . . . . . . . . . 12

The Biblical Approach: "By All Means" . . . . . . 14

The Place of the Holy Spirit in Mass Media

Evangelism ................. 16

Biblical Criteria for Success ... . . . . . . 19

Appropriate Criteria for Judging the Success
of Seed Sowing . . . . . . . . . . . . . . . . 22

The Latent Effect Factor.... . . . . . . . 24

III. A RATIONALE FOR RADIO SPOT EVANGELISM . . . . . . . . 29

The Context of Religious Radio Spots . . . . . 29

Background of Religious Radio Spots ........ 31

Expeditious Rationale for Using Religious
Radio Spots . . . . . . . . . . . . . 32

Theological Rationale for Using Religious

Radio Spots ................ 34

Research Support for Religious Radio Spots . . . . 37

IV. FORIAT CONSIDERATIONS IN RELATED RESEARCH . . . . . . 41

The Need for Radio-Format Research . . . . . . . 41

The Straight Announcer Format . . . . . . . 42

The Dialogue-Dramatization Format . . . . . . . 47

The On-the-Street Interview Format . . . . . . . 48

The Personal-Experience Format . . . . . . . . 49

Summary . . . . . . . . . . . . . 54 
V. DESCRIPTION OF SURVEY PROCEDURES .........

Introduction ...............

Definition of Terms ...........

Development of the Survey Instrument . . . . . . 56

The seven on-the-street interview sessions . . . 57

Survey instrument evaluations of Andrews

University faculty members ......... 60

Rationale for Survey Questions ......... 60

Questions 1 through 3.......... 62

Questions 4 through 9 .......... 67

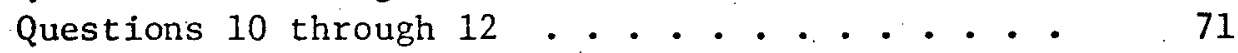

Implementation of the Survey ......... 73

VI. RESULTS OF THE SURVEY . . . . . . . . . . . 76

Introduction ............. . . 76

Overview of Demographic Findings . . . . . . . 76

Overview of Format Findings .......... . 77

Responses to Each Question According to

Relative Degree of Interest in Christianity . . . 79

Question 4: The Influence of Music on

Acceptability of Radio Spots for Nominal

and Non-Christians ..........

Question 5: The Influence of Music on

Credibility of Radio Spots for Nominal

and Non-Christians . . . . . . . . .

Question 6: The Influence of Four Format

Types on Acceptability of Radio Spots for

Nominal and Non-Christains . . . . . . .

Question 7: The Influence of Four Format.

Types on Credibility of Radio Spots for

Nominal and Non-Christians . . . . . . .

Question 8: The Influence of Three Types of

Communicators on Acceptability of Radio

Spots for Nominal and Non-Christians . . . . .

Question 9: The Influence of Three Types of

Communicators on Credibility of Radio

Spots for Nominal and Non-Christians . . . .

Responses to Each Question According to

Age Categories ............

Question 3: A Demographic Comparison of Age

Categories to Relative Degree of Interest

in Christianity ...........

Question 4: The Influence of Music on

Acceptability of Radio Spots According to

Age Categories of Respondents . . . . . .

Question 5: The Influence of Music on

Credibility of Radio Spots According to

Age Categories of Respondents ........ 
Question 6: The Influence of Four Format Types on Acceptability of Radio Spots According to Age Categories of Respondents . . . . . . .

Question 7: The Influence of Four Format Types on Credibility of Radio Spots According to Age Categories of Respondents . . . . . . .

Question 8: The Influence of Three Types of Communicators on Acceptability of Radio Spots According to Age Categories of Respondents . . .

Question 9: The Influence of Three Types of Communicators on Credibility of Radio Spots According to Age Categories of Respondents : . .

Responses to Each Question. According to

Race Categories . . . . . . . . . . . .

Question 3: A Demographic Comparison of Race Categories to Relative Degree of Interest in Christianity

Question 4: The Influence of Music on Acceptability of Radio Spots According to Race Categories of Respondents ...........

Question 5: The Influence of Music on Credibility of Radio Spots According to Race Categories of Respondents . . . . . . . .

Question 6: The Influence of Four Format Types on Acceptability of Radio Spots According to Race Categories of Respondents ..........

Question 7: The Influence of Four Format Types on Credibility of Radio Spots According to Race Categories of Respondents ..........

Question 8: The Influence of Three Types of Communicators on Acceptability of Radio Spots According to Race Categories of Respondents....

Question 9: The Influence of Three Types of Communicators on Credibility of Radio Spots According to Race Categories of Respondents . . 100 Responses to Each Question According to

Sex of Respondents ................ 104

Question 3: A Demographic Comparison of Sex of Respondents to Their Relative Degree of Interest in Christianity ...........

Question 4: The Influence of Music on Acceptability of Radio Spots According to the Sex of the Respondents . . . . . . . . . . .

Question 5: The Influence of Music on Credibility of Radio Spots According to the Sex of the Respondents... . . . . . . . .

Question 6: The Influence of Four Format Types on Acceptability of Radio Spots According to the Sex of the Respondents . . . . . . . . . .

Question 7: The Influence of Four Format Types on Credibility of Radio Spots According to the Sex of the Respondents . . . . . . . . . 
Question 8: The Influence of Three Types of Communicators on Acceptability of Radio Spots According to the Sex of the Respondents . . . .

Question 9: The Influence of Three Types of Communicators on Credibility of Radio Spots According to the Sex of the Respondents . . . .

Responses to Each Question Combining Age,

Race, and Sex Characteristics of Respondents . . .

Question 4: The Influence of Music on Acceptability of Radio Spots According to Age, Race, and Sex Characteristics of Respondents ..................

Question 5: The Influence of Music on Credibility of Radio Spots According to Age, Race, and Sex Characteristics of Respondents . . . . . . . . . . . . . .

Question 6: The Influence of Four Format Types on Acceptability of Radio Spots According to Age, Race, and Sex Characteristics of Respondents ...................

Question 7: The Influence of Four Format Types on Credibility of Radio Spots According to Age, Race, and Sex Characteristics of Respondents . . . . . . . . . . . . . . . Question 8: The Influence of Three Types of Communicators on Acceptability of Radio Spots According to Age, Race, and Sex Characteristics of Respondents... . . . . . . . . . . . . .

Question 9: The Influence of Three Types of Communicators on Credibility of Radio Spots According to Age, Race, and Sex Characteristics of Respondents . . . . . . . . . . . . . . .

Procedures and Results of the Interview

Session of June 22,1976 . . . . . . . . . . . .

APPENDIX B . . . . . . . . . . . . . . . . . . .

Questionnaire Used in the Interview

Session of June 29,1976 . . . . . . . . . . . . 


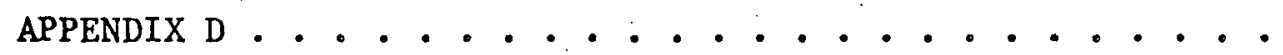

Questionnaire Used in the Interview

Session of July $20,1976 \ldots \ldots$. . . . . .

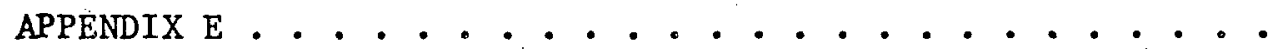

Questionnaire Used in the Interview

Session of July $23,1976 \ldots \ldots$

APPENDIX F . . . . . . . . . . . .

Questionnaire Used in the Interview

Session of September 2, $1976 \ldots . . . . .$.

APPENDIX G . . . . . . . . . . . . . . .

Term Definitions Form Used in the Interview

Session of September 13,1976 .........

APPENDIX H . . . . . . . . . . . . . .

The Names and Positions of Twenty-one Faculty

Members Who Were Sent Copies of a Preliminary

Survey Instrument .............

APPENDIX I . . . . . . . . . . . . . .

The Form Letter and Preliminary Survey Instrument

Sent to Twenty-one Andrews University Faculty

Members .......................

APPENDIX J . . . . . . . . . . . . . . . . .

A Copy of the Telephone Survey Instrument

Used in This Project... . . . . . . . . . . .

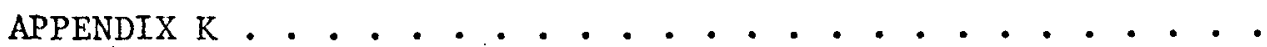

Scripts for the Thirteen-week Series of

Daily Radio Spots Produced as a Part of

This Project ..............

SELECTED BIBLIOGRAPHY . . . . . . . . . . . . 224

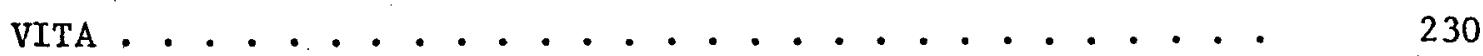


1. Races of the Respondents . . . . . . . . . . 76

2. Sex of the Respondents . . . . . . . . . . . . . 77

3. Age of the Respondents . . . . . . . . . . . 77

4. Location of the Respondents . . . . . . . . . . . 77

5. Respondents' Relative Degrees of Interest in Christianity .................... 77

6. The Influence of Music on Acceptability of Radio Spots ...................... 78

7. The Influence of Music on Credibility of Radio Spots ...................... . . 78

8. The Influence of Four Format Types on Acceptability of Radio Spots................... . 78

9. The Influence of Four Format Types on Credibility of Radio Spots... . . . . . . . . . . . . . 79

10. The Influence of Three Types of Communicators on Acceptability of Radio Spots . . . . . . . . . . . 79

11. The Influence of Three Types of Communicators on Credibility of Radio Spots . . . . . . . . . . . 79

12. The Influence of Music on Acceptability of Radio Spots for Nominal and Non-Christians . . . . . . . . 80

13. The Influence of Music on Credibility of Radio Spots for Nominal and Non-Christians . . . . . . . . . 81

14. The Influence of Four Format Types on Acceptability of Radio Spots for Nominal and Non-Christians . . . . . 82

15. The Influence of Four Format Types on Credibility of Radio Spots for Nominal and Non-Christians . . . . . 84

16. The Influence of Three Types of Communicators on Acceptability of Radio Spots for Nominal and Non-Christians . . . . . . . . . . . . . . .

17. The Influence of Three Types of Communicators on Credibility of Radio Spots for Nominal and Non-Christians . . . . . . . . . . . . . . . . .

18. A Demographic Comparison of Age Categories to Relative Degree of Interest in Christianity . . . . . . 88

19. The Influence of Music on Acceptability of Radio Spots According to Age Categories of Respondents . . . . 88

20. The Influence of Music on Credibility of Radio Spots According to Age Categories of Respondents . . .

21. The Influence of Four Format Types on Acceptability of Radio Spots According to Age Categories of Respondents . . . . . . . . . . . . . . .

22. The Influence of Four Format Types on Credibility of Radio Spots According to Age Categories of Respondents . . . . . . . . . . . . . . . 
23. The Influence of Three Types of Communicators on Acceptability of Radio Spots According to Age

Categories of Respondents . . . . . . . . . .

24. The Influence of Three Types of Communicators on Credibility of Radio Spots According to Age Categories of Respondents . . . . . . . . . .

25. A Demographic Comparison of Race Categories to Relative Degree of Interest in Christianity. . . . .

26. The Influence of Music on Acceptability of Radio Spots According to Race Categories of Respondents . .

27. The Influence of Music on Credibility of Radio Spots According to Race Categories of Respondents . .

28. The Influence of Four Format Types on Acceptability of Radio Spots According to Race Categories of Respondents . . . . . . . . . . . .

29. The Influence of Four Format Types on Credibility of Radio Spots According to Race Categories of Respondents . . . . . . . . . . . . . . 101

30. The Influence of Three Types of Communicators on Acceptability of Radio Spots According to Race Categories of Respondents . . . . . . . . . . .

31. The Influence of Three Types of Communicators on Credibility of Radio Spots According to Race Categories of Respondents ..............

32. A Demographic Comparison of Sex of Respondents to Their Relative Degree of Interest in Christianity . . . 104

33. The Influence of Music on Acceptability of Radio Spots According to the Sex of the Respondents . . . . 105

34. The Influence of Music on Credibility of Radio Spots According to the Sex of the Respondents . . . .

35. The Influence of Four Format Types on Acceptability of Radio Spots According to the Sex of the Respondents.................

36. The Influence of Four Format Types on Credibility of Radio Spots According to the Sex of the Respondents . . . . . . . . . . . .

37. The Influence of Three Types of Communicators on Acceptability of Radio Spots According to the Sex of the Respondents ..............

38. The Influence of Three Types of Communicators on Credibility of Radio Spots According to the Sex of the Respondents . . . . . . . . . . .

39. The Influence of Music on Acceptability of Radio Spots According to Age, Race, and Sex Characteristics of Respondents . . . . . . . . . . . . . . .

40. The Influence of Music on Credibility of Radio Spots According to Age, Race, and Sex Characteristics of Respondents . . . . . . . . . . . . . .

41. The Influence of Four Format Types on Acceptability of Radio Spots According to Age, Race, and Sex Characteristics of Respondents . . . . . . . . 
42. The Influence of Four Format Types on Credibility of

Radio Spots According to Age, Race, and Sex

Characteristics of Respondents . . . . . . . . . .

43. The Influence of Three: Types of Communicators on

Acceptability of Radio Spots According to Age,

Race, and Sex Characteristics of Respondents

44. The Influence of Three Types of Communicators on

Credibility of Radio Spots According to Age,

Race, and Sex Characteristics of Respondents . . . . 


\section{ACKNOWLEDGMENTS}

The author wishes to express his sincere appreciation to the administration of Andrews University for its encouragement and financial support which have made possible this project as well as the author's pursual of the D.Min degree.

The author also wishes to express his sincere appreciation to his D.Min Project Committee: Steven Vitrano (Chairman), William Garber, and Robert Cruise for their valuable assistance in this project. 


\section{CHAPTER - I}

\section{INTRODUCTION: AN OVERVIEW OF THE PROJECT}

\section{The Objective of the Project}

The objective of this project is to discover which of the most commoniy used radio production formats contribute most to acceptability and credibility of religious radio spots whose intended audience is either nominal or non-Christian, and to produce a thirteen-week series of daily, public-service radio spots for evangelistic purposes based on this determination.

\section{Justification of the Project}

(1) In recent years, many denominational churches have begun using religious radio spots as a means of attracting masses of people to the gospel as well as to the organization(s) sponsoring the messages. $^{1}$ Only within the past three years has the Seventh-day. Adventist Church begun to produce such spots. The need for carefu1, current research to discover which formats contribute most to acceptability and credibility in this area is therefore apparent.

(2) Although marketing and advertising firms spend millions of dollars annually to determine which types of commerical radio spots are most effective in appealing to specific audiences, a

1J. Harold Ellens, Models of Religious Broadcasting (Grand Rapids; Mich.: William B. Eerdmans Pub. Co., 1974), pp. 123-39. 
careful review of recent broadcast literature indicates that comparatively little of this research has been done by churches in general. This project is a serious attempt to provide the Seventhday Adventist Church at least some of that much needed information.

(3) Since it may be reasonably assumed that a large percentage or even the majority of radio listeners in the United States might be categorized as either nominal or non-Christian, the research of this project centers particularly on them.

(4) Since it is also possible that many local Adventist pastors might be using radio as a regular part of their evangelistic outreach to this class of persons, but are not doing so at present because they may sense a lack of necessary training, equipment, and time that are all required to produce professional quality religious radio spots locally, the series of spots produced as a result of this project could provide these pastors with a researched tool to assist them in introducing the gospel to this specialized audience.

(5) This researcher further has found, as originally anticipated, that this project has enabled him to share new and valuable insights in approaches to radio evangelism with his students in the seminary religious broadcasting class.

\section{Description of the Project}

(1) As a basis for this project, the researcher has undertaken a study and theological reflection of the place of radio in the mission of the church.

(2) The researcher has further undertaken a careful review of current broadcast literature--both published and unpublished--dealing 
with persuasive radio techniques. This information, in addition to providing a frame of reference for the project, also aided in the development of specific questions in the survey conducted as a part of the project.

(3) An on-the-street interview pilot study was conducted in the Benton Harbor-St. Joseph, Michigan, area to ascertain reasons why people listen to or try to avoid listening to religious radio messages. This effort utilized primarily open-ended questions to give the interviewees an opportunity to answer as candidly as possible and to provide the researcher with creative ideas for specific questions to be included in the later survey.

(4) A survey instrument was then drawn up and pretested by on-the-street interviews in the Benton Harbor-St. Joseph area. The purpose of this pretest was to refine word choices and sentence structures to clarify intended meaning where needed.

(5) Nine hundred persons were selected (by use of a random number table) from the 1976-77 Benton Harbor-St. Joseph Telephone Directory. These nine hundred persons were called on the phone to ascertain, according to a predetermined set of criteria, those who were either nominal or non-Christians and to survey by phone those selected to discover which of the commonly used radio production formats contribute most to credibility and acceptability of religious radio spots for them.

(6) A careful data analysis was then undertaken to ascertain which production techniques contribute most to credibility and acceptability of religious radio spots, based on the perceptions of the respondents. 
(7) An on-paper radio spot model was then devised incorporating those techniques which, based on the research, contribute most to credibility and acceptability for the intended audience.

(8) A thirteen-week series of daily (Monday through Friday) religious radio spots based on the model devised from the data gathered was then produced. This series of spots was produced using the facilities of WAUS-FM on the campus of Andrews University. 
CHAPTER II

A THEOLOGICAL BASIS FOR MASS MEDIA EVANGELISM

The Need for a Biblical Understanding of Mass Media Evangelism

The need for a Biblical understanding of the role of the mass media in the mission of the church as been persistently lacking for years. This lack is voiced in the "Mass Communications Report of the International Congress of World Evangelization," held in Lausanne, Switzerland, July 16-25, 1974:

First, we feel there is a need for a genuinely Biblical, theological basis for our use of the mass communications media.

Writing on the subject is needed as well as teaching in Christian schools and training centers throughout the world.1

A careful review of religious broadcasting literature confirms this need. Few books, and still fewer articles, even allude to this critical issue. This chapter, therefore, is an attempt to provide an understanding of the place of the mass media in the mission of the church.

\section{A Biblical Precedent for Mass Media Evangelism}

Eugene A. Nida aptly expresses the starting premise of this paper when he writes, "The basic theological justification of our communicative procedures must rest ultimately on what God has

$1^{1}$ Phil Butler, "Mass Communication Report," Let the Earth Hear His Voice, ed. J. D. Douglas (Minneapolis, Minn.: World Wide Publications, 1974), p. 1311. 
revealed about His own communication with man."1

When man first sinned, ${ }^{2}$ he lost the privilege of face-to-face communion with his Creator. ${ }^{3}$ The prophet Isaiah, writing in spiritual terms of this physical separation, states: "But your iniquities have separated between you and your God, and your sins have hid His face from you." 4

Nevertheless, since the fall of man, a loving God has been seeking--through a variety of media--to bridge the communication gap brought about by sin, and by so doing, to instruct man in His will. 5 Following are examples of the many communication media employed by God:

(1) His created works. God speaks to man's senses through the medium of nature. "The heavens declare the glory of God; and the firmament showeth forth His handiwork. Day unto day uttereth speech, and night unto night showeth knowledge." 6

(2) The sacrifical system. The first allusion to this medium of communication is the painful story of the sacrificial offerings of Cain and Abel. Speaking of the lamb offered by Abel (intended by God to communicate the truth of the coming Lamb of God "which taketh away

$1_{\text {Eugene A. Nida, Message and Mission: The Communication of the }}$ Christian Faith (New York: Harper and Row, Pub., 1960), p. 221.

2 Gen $1-3$.

3 Ex $33: 20$; cf. Gen $3: 8$ and Ex $33: 21-23$.

${ }^{4}$ Isa $59: 2$.

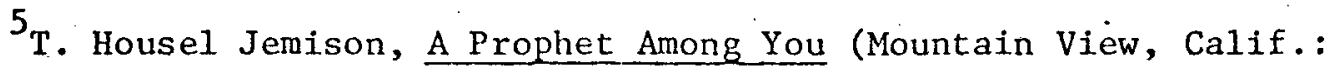
Pacific Press Pub. Assn., 1955), p. 19.

${ }^{6}$ Ps 19:1-2. (Italics mine.) Cf. Rom 1:20 and Acts 14:17. 
the sin of the world"1), the Divine Record indicates that "the Lord has respect unto Abel and his offering: But unto Cain and to his offering He had not respect." 2 Thus, the Divine lesson was taught: God's medium of communication (e.g. the sacrifice of the innocent lamb) is not to be regarded lightly.

(3) The rainbow. After the flood, God used the medium of a rainbow to communicate to man His promise that never again would He destroy the earth with a flood. "I do set My bow in the cloud, and it shall be for a token of a covenant between Me and the earth. " ${ }^{3}$

(4) The Sabbath. Since He instituted the Sabbath on the seventh day of creation week, God has communicated with man through the medium of time. "Moreover also I gave them My sabbaths, to be a sign between Me and them, that they might know that I am the Lord that sanctify them." $" 4$

(5) The Urim and Thummin. Through the medium of these two precious stones in the breastplate of Israel's High Priest, God communicated His will to the Children of Israel. 5

(6) "Fiery serpents." On one occasion, God used the medium of "fiery serpents" to communicate with Israel about their need for repentance. When Israel did repent, "The Lord said unto Moses, Make thee a fiery serpent, and set it upon a pole: and it shall come

${ }^{1}$ John $1: 29 . \quad{ }^{2}$ Gen 4:4-5.

${ }^{3}$ Gen $9: 13$ (italics mine); cf. vs. 14-17.

${ }^{4}$ Ezek 20:12. (Italics mine.) Cf. Ex 31:13.

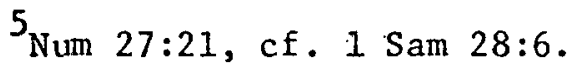


to pass, that everyone that is bitten, when he looketh upon it, shall live." 1

(7) Angels. Constantly, and on numerous, specifically recorded occasions, God has used the medium of angels to communicate with man. "Are they not all ministering spirits, sent forth to minister for them who shall be heirs of salvation?"

(8) Dreams. Through this medium, God's revealed will has been made known to specific persons at specific times. For example, the dreams of Joseph, ${ }^{3}$ Pharoah, ${ }^{4}$ Pharoah's butler and baker, ${ }^{5}$ and Nebuchadnezzar. 6

(9) Voice from heaven. Only on very few and significant occasions has God used the medium of His own voice from heaven. The 01d Testament records two notable occurences: (a) at Mount Sinai, ${ }^{7}$ and (b) to Moses, Aaron, and Miriam together. ${ }^{8}$ Most of the occurences in the New Testament happened during Jesus' brief ministry on earth. 9

(10) Holy Spirit. As will be noted in greater detail later in this paper, God further communicates with man through the medium of His Spirit. ${ }^{10}$

(11) Prophets. Through the medium of prophets God has made known His will. "Surely the Lord God will do nothing, but He revealeth His

$1_{\text {Num } 21: 4-9 . \quad \text { (Italics mine.) }}$

${ }^{2}$ Heb 1:14; cf. Ps $34: 7$; Gen 19:15; Num 22:31-35.

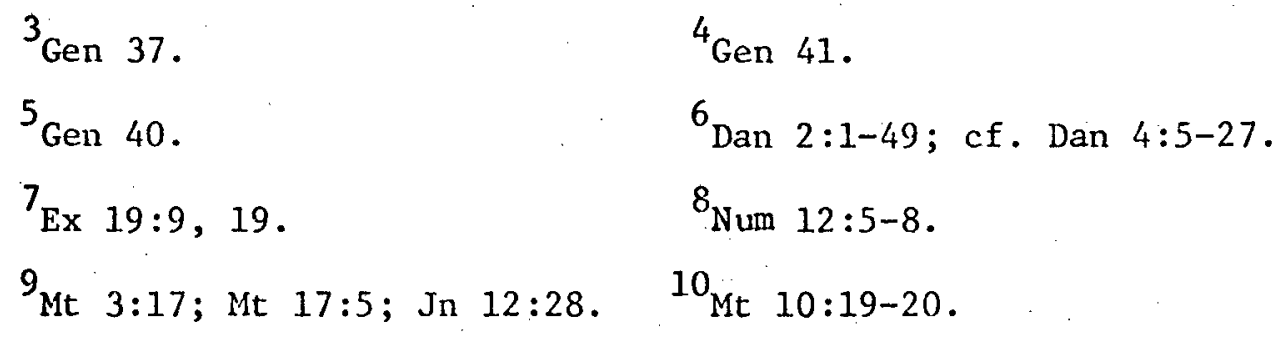


secret unto His servants the prophets." 1 Indeed, "if there be a prophet among you, I the Lord will make Nyself known unto him in a vision, and will speak unto him in a dream." 2

(12) Scripture writings. God communicates with man through the medium of man's own word-symbols--whether hand written on papyrus or printed in mass using high-speed presses. "All scripture is given by inspiration of God, and is profitable for doctrine, for reproof, for correction, for instruction in righteousness." 3

(13) Jesus Christ Himself. God's ultimate communication medium-that which man could best understand--was the incarnation of Jesus Christ. "God, who at sundry times and in diverse manners, spake in times past unto the fathers by the prophets, hath in these last days spoken unto us by His Son." 4

Clearly, God is multi-media in His communicative approach to man. An awareness of this Biblical communication precedent provides a useful reference point in one's determination of the validity of the use of mass media by the church today.

\section{Incarnation: The Ideal of Divine Communication}

A major reason for God's multi-media communicative approach to man may be His great desire to identify Himself--in as many ways as possible--with His wayward children, created in His own image. 5 Thus, God "after many types of communication through the centuries,

${ }^{1}$ Amos $3: 7$.

$3_{2} \operatorname{Tim} 3: 16$.

${ }^{5}$ Gen $1: 27$.
${ }^{2}$ Num $12: 6$.

${ }^{4}$ Heb $1: 1-2 ;$ cf. Jn $1: 1-3,14$. 
at last chose the incarnation itself as the ultimate statement in His use of media." 1

As Hendrik Kraemer puts it: "The true and deepest sense of this manward Divine urge permeating the Biblical record of God's peculiar character finds expression in the name Immanuel, 'God with us,' given to Jesus Christ the Word made flesh." 2

Indeed, as the Word became flesh, flesh could better understand the Word. Thus, "Christ took humanity that He might reach humanity." 3

In this regard, Eugene A. Nida points out that

- . all Divine communication is essentially incarnational for it comes not only in words, but in life. Even if a truth is given only in words, it has no real validity until it has been translated into life. Only then does the Word of life become life to the receptor. The words are in a sense nothing in and of themselves. Even as wisdom is emptiness unless lived out in behavior, so the Word is void unless related to experience. In the incarnation of God in Jesus Christ, the Word (the expression and relation of the wisdom of God) became flesh. This fundamental principle has been followed throughout the history of the church, for God has constantly chosen to use not only words but human beings as well to witness to His grace; not only the message, but the messenger; not only the Bible, but the church. 4

To the Christian communicator, the implications of Christ's incarnation are momentous, since "the incarnation, life teaching,

${ }^{1}$ Philip Butler, "Evangelism and the Media: A Theological Basis for Action," Let the Earth Hear His Voice, ed., J. D. Douglas (Minneapolis, Minn.: World Wide Publications, 1974), p. 527.

2 Hendrik Kraemer, The Communication of the Christian Faith (Philadelphia: The Westminster Press, 1956), p. 15.

3Ellen G. White, The Acts of the Apostles (Mountain View, Calif.: Pacific Press Pub. Assn., 1911), p. 134.

${ }^{4}$ Nida, p. 226. 
and work of Christ is meant to be the Christian's pattern."1

Unfortunately, as John Stott writes,

It comes more natural to us to shout the gospel at people from a distance than to involve ourselves into their culture and their problems, and to feel with them in their pain. Yet this implication of our Lord's example is inescapable.2

By incarnation God thoroughly identified Himself with man. In 1ike manner, the Christian communicator should strive to identify with his fellow man. As David Augsburger puts it,

Incarnation means enfleshing. To put God's Word into human form, to express it in human terms, to live it out in a human body. To flesh out the truth of God in the grubby intercourse of the workbench or the market place. ${ }^{3}$

In sum, "Lessons must be given to humanity in the language of humanity." 4 To follow his Lord's example, then, the Christian communicator must give the lessons for humanity in the language of humanity, using the media of the world to express the Good News of salvation in Jesus Christ. "Without compromising the truth of the Gospel," he "must see to it the Word becomes flesh in our time." 5

${ }^{1}$ David W. Augsburger, Communicating Good News (Newton, Kansas: Faith and Life Press, 1972), p. 50.

2 John R. W. Stott, Christian Mission in the Modern World (Downers Grove, Illinois: InterVaristy Press, 1975), p. 25.

3 Augsburger, p. 50 .

${ }^{4}$ E1len G. White, The Story of Prophets and Kings (Mountain View, Calif.: Pacific Press Pub. Assn., 1943), p. 700.

${ }^{5}$ E. G. Homrighausen, "Evangelism: Ministry of the Church," in Evangelism and Pastoral Psychology, ed. Simon Doniger (Great Neck, N.Y.: Pastoral Psychology Press, n.d.), p. 22. 
Incarnation: The Ideal of

Christian Communication

Both before and after the bodily incarnation of Jesus, God condescended to manifest revelations of Himself in the words of men.

Thus "Holy men of God," using the language symbols and writing media of their day, wrote "as they were moved by the Holy Ghost."1

In fact, throughout history the prophets and preachers have been bound up with the methods of communication practiced in their society. The Hebrew prophets, intent on reaching their countrymen, preached striking sermons illustrated by vivid object lessons. ${ }^{4}$ Christian preachers used the language of the shop and street in their sermons and in the letters written to members of the young Church scattered throughout the ancient world. Several of the early Church fathers, such as Chrysostom, Basil the Great, and Augustine were strongly influenced by the secular rhetoric spawned in Greece and Rome. Medieval tractates on preaching written during the twelfth and thirteenth centuries reflect the continued influence of the classical rhetoric on the Christian sermon. 2

${ }^{4}$ See Ezekie1 4 or Hosea $1: 1-3$.

Don Gillis expands this point in the following historical

insight:

Historically the church has been centuries ahead of everyone in the employment of media to instruct, for graphic arts and music (two of the most potent media forces) were used at the outset to teach great masses of people. These masses for the most part were unable to read or write and they depended upon such teaching aids as tunes whose words were Scriptural, stained glass windows, statuary and paintings for information about Biblical characters and events. ${ }^{3}$

$1_{2}$ pet $1: 21$.

2 Haddon William Robinson, "A Study of the Audience for Religious Broadcasts in Onondaga County" (Ph.D. thesis, University of Illinois, 1964), p. 2 .

${ }^{3}$ Don Gillis, The Art of Media Instruction (Dallas, Texas: Crescendo Book Publishers, 1973), p. 260. 
Thus the message of the Word was incarnated--that is, enfleshed or made concrete rather than abstract or numinous among the masses.

Undoubtedly the greatest increase in the church's incarnative use of the mass media occured when "the Protestant Reformation made use of the printing press," ${ }^{1}$ "like a loaded cannon." ${ }^{2}$ And "primarily because of mass communication did the attack of the Reformers become shouts heard 'round the world. ${ }^{3}$

Again, in the nineteenth century,

Soren Kierkegaard, the "apostle of inwardness," realized that he must use a mass medium of communication if he were to influence the people of Denmark. He felt that sermons were often wasted in churches and should be preached in the midst of real life. As a result, Kierkegaard published his polemical articles in a politcal journal, The Fatherland, since he believed that this was a strategic medium through which to demonstrate the gospel's conflict with everyday experience. ${ }^{4}$

The printed page was incarnating the message of the Word.

Yet one problem remained: How to "reach" the illiterate portion of

the world. Radio broadcasting was a logical answer.

Only two months after KDKA pioneered commercial broadcasting, the Pittsburgh station aired, on January 2, 1921, the Sunday morning service by remote control from the Calvary Episcopal Church in the same city. A Catholic mass was aired two years later in. St. Louis. Several of the first commercial broadcasting stations were owned and operated by churches or religious organizations. 5

Clearly, as William F. Fore points out in his book Image and

Impact: How Man Comes Through in the Mass Media,

God never stands still. He is always ahead of us, speaking where we least suspect. But one thing is certain: He speaks

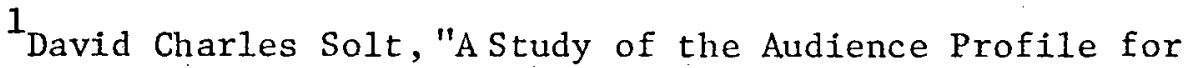
Religious Broadcasts in Onondaga County" (Ph.D. dissertation, Syracuse University, 1971), p. 31.

$$
\begin{aligned}
& { }^{2} \text { Robinson, p. 2. } \\
& { }^{5} \text { Solt , p. 3. }
\end{aligned}
$$


through whatever channels are used the most and in our time this includes the mass media of communication. ${ }^{1}$

Admittedly, "this view of God's acting may be disturbing.

It may require a new orientation to the media. But it is Biblical." ${ }^{2}$ Thus, through Isaiah came God's challenge: "Behold, I am doing a new thing. Even now it springs to light. Do you not perceive it?" ${ }^{3}$

\section{The Biblical Approach: "By All Means":}

Paul's philosophy of Christian communication included the use of whatever media or approaches were relevant to the successful propagation of the gospel. "By all means (to) save some" ${ }^{4}$ was his technique, which he defended with the declaration "that i might: gain the more." 5

The principle applies today.

If "faith cometh by hearing, and hearing by the Word of God," (Rom. 10:17), then radio easily, quickly, and economically provides a vastly increased opportunity for multitudes on the foreign fields to "hear" the life saving messages of salvation.

The noted Christian writer Ellen G. White makes these additional striking comments pertinent to Paul's "by-all-means-(to)-savesome" principle:

God entrusts men with talents and inventive genius, in order that His great work in our world may be accomplished. The

${ }^{1}$ (New York: Friendship Press, 1970), pp. 12-13.

${ }^{2}$ Ibid.

${ }^{3}$ Isa $43: 19$, as translated in Fore, p. 13.

${ }^{4} 1$ Cor $9: 22$. (Italics mine.)

51 Cor $9: 19$.

${ }^{6}$ Clarence W. Jones, Radio--the New Missionary (Chicago: Moody Press, .1949), p. 95. 
inventions of human minds are supposed to spring from humanity, but God is behind all.

We must take every justifiable means of bringing the light before the people. Let the press be utilized, and let every advertising agency be employed that will call attention to the work. This should not be regarded as nonessential. On every street corner you may see placards and notices calling attention to various things that are going on, some of them of the most objectionable character; and shall those who have the light of life be satisfied with feeble efforts to call the attention of the masses to the truth? ${ }^{2}$

God has placed instrumentalities in our hands, and we must use every one of them to do His will and way. As believers we are privileged to act a part in forwarding the truth for this time. As far as possible we are to employ the means and agencies that God has given us to introduce the truth into new localities. 3

White adds, that "the end is near, and for this reason we are to make the most of every entrusted ability and every agency that shall offer help to the work." ${ }^{4}$ In essence, it is a matter of "redeeming the time," such large numbers at low cost is a most practical response to our Lord's command for wise stewardship found in Mt 24:14-30--the parable of the talents. "6

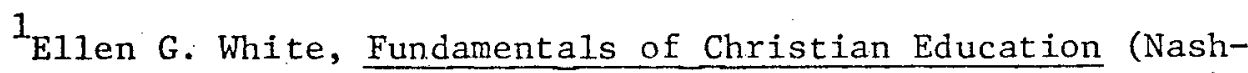
ville, Tenn.: Southern Pub. Assn., 1923), p. 409. (Italics mine.)

2 E1len G. White, Evangelism (Washington, D.C.: Review \& Herald Pub. Assn., 1946), p. 130. (Italics mine.)

${ }^{3}$ E1len G. White, Testimonies to Ministers and Gospel Workers (Mountain View, Calif.: Pacific Press Pub. Assn., 1962), p. 424.

${ }^{4}$ Ellen G. White, Testimonies for the Church, 9 vols. (Mountain View, Calif.: Pacific Press Pub. Assn., 1948), 6:440.

${ }^{5}$ Eph 5:16-17; cf. Col 4:5.

${ }^{6}$ Butler, "Evangelism and the Media: A Theological Basis for Action," pp. 526-27. 
The Place of the Holy Spirit

in Mass Media Evangelism

The Christian communicator must remember that he "can use the mass media, but only as tools. They aren't the end-all and be-all of Christian witness nor the ultimate solution to the Great Commission."1

This may be partially attributed to the generally recognized fact that "the more personal the medium the more effective it is likely to be in channeling communication. Thus, the give-and-take of personal conversation is superior to one-way broadcasting which, in turn, has advantages over the print media." ${ }^{2}$

In a larger sense, however, the reason why mass media are not "the ultimate solution to the Great Commission" lies not in the hindering factor of the so-called "synthetic togetherness" ${ }^{3}$ afforded by the mass media, so much as it does in the Divine variable of the Holy Spirit. For, in reality, no communication medium can do the work of God Himself, who both originates and incarnates the Word by His Spirit in men's hearts. That is why, in order to properly understand the role of the mass media in evangelism, it is vital to note a significant difference between man's interpersonal (between persons) communication and God's intrapersonal (within the person) communication.

While man's interpersonal communication is generally thought

${ }^{1}$ Emory Griffin, "The Role of Media in Changing Attitudes," Spectrum, Summer, 1976, p. 7.

2 John W. Bachman, The Church in the Wor1d of Radio-Television (New York: Association Press, 1960), p. 20.

${ }^{3}$ Ibid., p. 116. 
to be his most effective communication approach, it may well be that Intrapersonal communication is the more effective as a Divine communIcation approach. Perhaps for that reason, since man's fall God has been using a variety of media perceived by man internally (intrapersonal communication). And not until we are changed "in a moment, in the twinkling of an eye, at the last trump, 1 (second coming of Jesus), will God's interpersonal ideal be again realized. Meanwhile, God condescends to speak His Word through men to other men. But it is not men who convert men. It is the Holy Spirit who converts men. This is an internal (intrapersonal) process. Indeed, men may persaude other men. Intellectual assent may be obtained. Yet there may be no real change in a person's life. The Holy Spirit is needed to incarnate the Word at a deeper leve1-the level of the will, man's power of choice, the center of his actions. 2

Another important distinction is thus made--namely, that "the peculiar character and place of communication of the Christian message appears in the fact that its inherent aim is not persuasion - . but conversion. ${ }^{3}$ Further, that communication which converts is "not by might, nor by power, but by My Spirit, saith the Lord of hosts." As Ellen G. White has written: "No eloquence of words, no

${ }_{1} \operatorname{Cor} 15: 51-53$.

${ }^{2}$ Ellen G. White, Steps to Christ (Mountain View, Calif.: Pacific Press Pub. Assn., 1956), p. 47.

3 Kraemer, pp. 28-29.

${ }^{4}$ Zech $4: 6$. 
force of argument can convert the sinner. The power of God alone can apply the truth to the heart." 1

Therefore the apostle Paul wrote, "My speech and my preaching was not with enticing words of man's wisdom, but in demonstration of the Spirit and of power: But God hath revealed them unto us by His Spirit: for the spirit searcheth all things, yea, the deep things of God." ${ }^{2}$ And to the Thessalonians he wrote, "For our gospel came not unto you in word only, but also in power, and in the Holy Ghost, and in much assurance; and ye became followers of us, and of the Lord." ${ }^{3}$

Such power is the result of one central fact stated by Jesus Christ: "For it is not ye that speak, but the Spirit of your Father which speaketh in you." 4 Again, for "it is not ye that speak, but the Holy Ghost." 5

Thus, Hendrik Kraemer writes that

Throughout the Bible it is consistently maintained that the primary author of effective transmission of the message is the Holy Spirit. This demonstrates clearly that communication of the gospel has a quality of its own, different from communication as generally understood and on a different level. . . It is not simply communication between two partners, but the invisible partner, the Holy Spirit, is the chief one. 6

The following comments by Nida provide a useful elaboration

of the basic point being made here:

Only by the supernatural activity of the Spirit can men possibly experience for themselves the transforming grace of God. . . . We ourselves do not communicate this message; we only bear witness to its truth, for it is the Spirit of God that directly

White, The Acts of the Apostles, p. 240.

2 Rom $11: 33-34$.

$31 \mathrm{Th} 1: 5-6$.

${ }^{4} \mathrm{Mt} 10: 20$.

${ }^{5} \mathrm{Mk} 13: 10$.

${ }^{6}$ Kraemer, p. 28. (Italics mine.) 
communicates and mediates this Divine word. The encounter which men have is not merely with an idea, but with God Himself.

Hence, the communication in which we are involved is not only supernatural in content (in that it is derived from God); it is also supernatural in process, for the Spirit of God alone makes this message to live within the hearts of men. 1

Clearly, "the source of evangelistic power is the Holy Spirit." 2 Yet "it is not for you to use the Holy Spirit of God, but it is for the Holy Spirit to use you." 3

\section{Biblical Criteria for Success}

A Biblical criterion for the success of the Christian use of mass media lies in an understanding of the nature of the ministry of the church." "Fundamentally, the church is engaged in only one ministry, but this ministry has different facets." 4

Paul expressed this truth in his letter to the church at

Ephesus. "And he gave some, apostles; and some, prophets, and some, evangelists; and some, pastors and teachers: For the perfecting of the saints, for the work of the ministry, for the edifying of the body of Christ." 5

The possibly sequential, redemptive ordering of the gifts in this passage deserves at least passing consideration. God begins His reaching out to the unbelieving world through the apostles, who

${ }^{1}$ Nida, pp. 228-29. (Italics mine.)

${ }^{2}$ C. E. Autrey, Basic Evangelism (Grand Rapids, Mich.: Zondervan Publishing House, 1959), p. 40.

3 White, Testimonies to Ministers, p. 76. pp. 17-22.

4 Homrighausen, "Evangelism: Ministry of the Church,"

${ }^{5}$ Eph 4:12-13. 
proclaim God's Good News. The telling-forth of the prophets brings conviction. Under the influence of the Holy Spirit, the work of the evangelist contributes largely to the process of conversion. The spiritual nurture of the pastors and teachers helps to establish converts, whose witness, in turn, is an apostolic proclamation of God's merciful dealing in their own lives.

Typically, of course, people are not contacted progressively according to.Paul's apparently sequential ordering of the gifts. Nevertheless, the basic flow of God's redemptive activity is evident here. God first proclaims, then convicts, then converts, then nurtures, then--through the converted--proclaims again. Indeed, there is not conviction without proclamation. And there is not conversion without conviction. Neither is there nurture without con- . version.

Clearly, God's redemptive approach to man is holistic in nature. Jesus expressed this truth in His parable of the sower, ${ }^{1}$ a parable which perhaps "has not been valued as it should be." 2 In essence, Jesus said that even as seed sowing precedes harvest, proclamation precedes conversion. Each phase is mutually dependent. There cannot be one without the other. ${ }^{3}$

This is an important point for the church to ponder. Evangelism "includes the total task of sowing, watering, and

${ }^{1}$ Mt 13:1-9, 18-23; Mk 4:1-20; Lk 8:4-15.

2 Ellen G. White, Christ's Object Lessons (Washington, D.C.: Review \& Herald Pub. Assn., 1941), p. 33 .

${ }^{3}$ Ellen G. White, Gospel Workers (Washington, D.C.: Review \& Herald Pub. Assn., 1915), p. 26. 
reaping." 1 These words "outline God's plan." 2

For this reason Paul wrote, "I have planted, Apollos

watered; but God gave the increase. So then neither is he that planteth anything, neither he that watereth; but God that giveth the increase." 3

Thus Jesus Christ said, "And herein is that saying true, one soweth, and another reapeth. I send you to reap that whereon ye bestowed no labor: other men labored, and ye are entered into their labors." 4

The Psalmist adds, "He that goeth forth and weepeth, bearing precious seed, shall doubtless come again with rejoicing, bringing his sheaves with him. "5

From these Scripture references it is evident that God's plan requires both sowing and reaping. Yet while He uses "some to sow and some to reap" $\mathrm{His}$ workers should "remember that they are never to take to themselves the glory for the success of their work, "7 since it is "God that giveth the increase." 8 "To the Master Worker belongs the honor and glory that comes with success." 9

Within the framework of this holistic approach to evangelism lies a significant implication for Christian broadcasters. Since-as will be further noted--broadcasting is essentially a seed-sowing

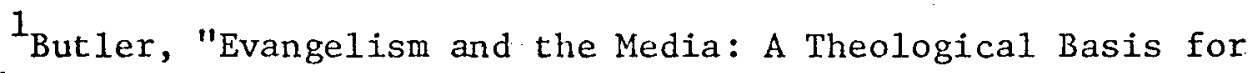
Action," p. 529 .

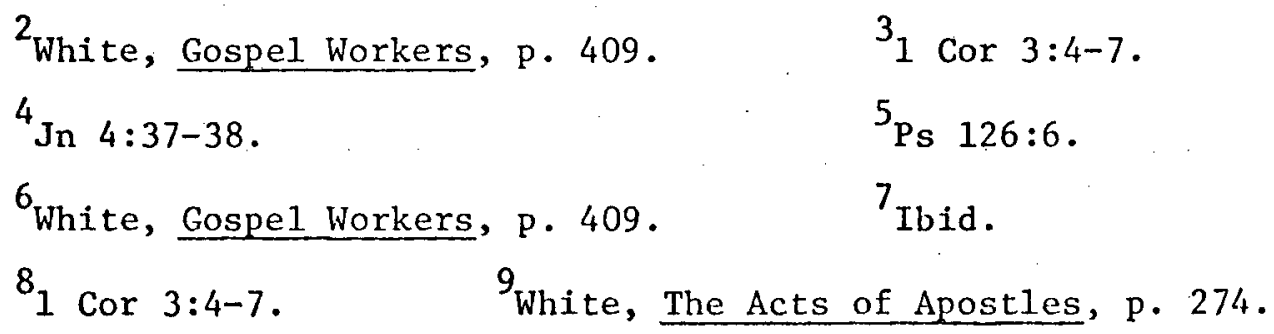


effort; and since seed sowing is part of God's holistic redemptive plan, the Christian's use of broadcasting is also a part of God's holistic redemptive plan. If that is true, perhaps the church should take greater cognizance of this influential tool.

\section{Appropriate Criteria for Judging} the Success of Seed Sowing

Undoubtedly, one reason why the church has partially neglected greater use of broadcasting is that relatively few baptisms appear to result from this effort. The tendency is to judge success on the basis of immediately visible externals (e.g., increase in. church membership) rather than on the basis of whether or not we are faithfully proclaiming the Word of God.

In response to this tendency, it should be noted that Jesus sought to proclaim God's message irrespective of the "results." His work was to sow, "to proclaim liberty to the captives, and the opening of the prison to them that are bound; to proclaim the acceptable year of the Lord, and the day of vengence of our God." ${ }^{1}$. But the "conversions that took place on the Day of Pentecost were the result of this sowing, the harvest of Christ's work." ${ }^{2}$

Was Jesus Christ not successful because He did not reap? Was He a failure as an Evangelist?. Of course not. Evangelism involves proclaiming God's Word--irrespective of baptisms.

Noah "sowed the seed" for 120 years $^{3}$ in obedience to the

${ }^{1}$ Isa $61: 1-2$; cf. Lk $4: 18-19$.

White, The Acts of the Apostles, p. 45.

${ }^{3}$ Gen 6-8. 
command of God. None were converted. Was Noah a failure? Should he ever have stopped proclaiming God's Word through the "foolishness of preaching?"1 of course not. For Noah evangelism was doing the will of God--irrespective of how many might enter the ark.

Thus, as J. I. Packer points out, "The way to tell whether in fact you are evangelizing is not to ask whether conversions are known to have resulted from your witness. It is to ask whether you are faithfully making known the gospel message. " ${ }^{2}$

John Stott affirms this principle with considered insight:

Evangelism must not be defined in terms of results, for this is not how the word is used in the New Testament. Normally the verb is in the middle voice. Occasionally it is used absolutely, for example "there they evangelized," meaning "there they preached the gospel" (Acts 14:7 cf. Romans 15:20). Usually, however, something is added. Sometimes it is the message they preached, e.g. they "went about evangelizing the word" (Acts 3:12). Sometimes, however what is added is the people to whom or the places in which the gospel was preached. For example, the apostles "evangelized many villages of the Samaritans" and Philip "evanglized all the towns along the Palestinian coast (Acts $8: 25,40$ ). There is no mention in these verses whether the word which was evangelized was believed, or whether the inhabitants of the towns and villages "evangelized" were converted. To "evangelize" in New Testament usage does not mean to win converts, as it usually does when we use the word. Evangelism is the announcement of the good news; irrespective of the results. ${ }^{3}$

James Engel, noting that proclamation must precede persua-

sion, further adds that a great error was made

- . when we assume without evidence that communication, to be effective, must result in large numbers of converts and consequent church growth. This will happen only when there are large

$1_{1}$ Cor . $1: 18$.

${ }^{2}$ J. I. Packer, Evangelism and the Sovereignty of God (n.p., n.d.), quoted in John R. W. Stott, pp. 38-40.

3 Stott, p. 38. (Italics mine.) 
numbers who have progressed to the point that persuasion is the appropriate strategy. The fundamental purpose always is to bring spiritual growth in people as they progress in decision processes, not just numerical growth in the church. 1

"Now of course our objective is that something will happen, namely that people will respond and believe. That is why we plead with them to 'be reconciled with God'" (2 Cor 5:20), ${ }^{2}$ writes John Stott. Nevertheless, a tendency among some Christian observers is

to

- . confuse an objective (what we want to happen) with a consequence (what actually does happen). If we want to be Biblically accurate we must insist that the essence of evangelism lies in the faithful proclamation of the gospel. It is with a view to persuasion indeed. We are not indifferent to results. We long for people to be converted. But it is still evangelism whether in fact men are persuaded to embrace it or not. 3

C. E. Autrey further affirms this point, stating that

A healthy New Testament evangelism will add great numbers to our churches. But the goal of the evangelism of Jesus is the conversion of the individual, and not an ever lengthening church ro11. Never decry numbers if numbers represent redeemed souls, but make sure your goal is to redeem rather than to count. 4

\section{The Latent Effect Factor}

In any consideration of the criteria for success in mass media evangelism, an important distinction must be remembered. Evangelism is--in its human dimension--essentially interpersonal (between persons). While genuine conversion-the hoped-for product

${ }^{1}$ James Enge1, "The Audience for Christian Communication," Let the Earth Hear His Voice, ed., J. D. Douglas (Minneapolis, Minn.: Wor1d Wide Publications, 1974), pp. 536-37.

$$
{ }^{2} \text { stott, p. } 40 \text {. } \quad 3 \text { Ibid. }
$$

${ }^{4}$ C. E. Autrey, Basic Evangelism (Grand Rapids, Mich.: Zondervan Publishing House, 1959), pp. 27-38. (Italics mine.) 
of evangelism--is essentially intrapersonal (within the person).

Nevertheless, man's tendency is to judge his evangelistic

success on the basis of visible interpersonal factors (e.g., the number of baptisms resulting from an "effort" in a given amount of time).

Two deceptive assumptions are evident in this thinking. The first is that the evangelizer himself is capable of judging his own success. And secondly, that if the evangelistic approach failed to meet the expectations of the evangelizer, there is something inherently wrong with the approach.

Regarding the first assumption, it must be remembered that only God is truly capable of evaluating any degree of evangelistic success, "for the Lord seeth not as man seeth; for man looketh on the outward appearance, but the Lord looketh on the heart." 1 Men simply cannot read other men's hearts. Jesus affirmed this in His scathing rebuke to the scribes and Pharisees: "Ye also outwardly appear righteous unto men, but within ye are full of hypocrisy and iniquity," ${ }^{2}$ For that reason, John counsels that we "judge not according to the appearance. ${ }^{3}$

In other words, the number of baptisms resulting from an evangelistic "effort" may not necessarily be an accurate indicator of evangelistic success--since it is possible for persons to be persuaded to be baptized, without really being converted. On the other hand, of course, one should not necessarily be refused baptism
$1_{1 \text { Sam } 16: 7 .}$
${ }^{2}$ Mt $23: 27-28$.

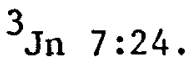


simply on the basis that God alone knows when conversion has taken place.

The critical point is this. If conversion not numbers of baptisms) is the primary object of true evangelism, and man is virtually incapable of determining when conversion has taken place (except on the basis of often faulty external indicators), then man is incapable of correctly evaluating evangelistic success. God alone can do that, since God alone can read hearts.

Regarding the second deceptive assumption that there is something inherently wrong with the evangelistic approach if it fails to meet the expectations of the evangelizer, it may be that the expectations of the evangelizer are faulty, not the approach. Again, it may be that the evangelizer is depending more on a certain approach than on God. When this is the case, the words of Zechariah have been forgotten: "Not by might, nor by power, but by My Spirit, saith the Lord." 1

Further, the evangelizer may be evaluating the "outcome" on the basis of criteria which really do not apply to the approach at all (e.g., judging the success of a Christian radio program by the number of baptism resulting from it within a certain time nay be like trying to evaluate the "effectiveness" of a painting in an art gallery by the number of people who tried to buy it, also in a certain amount of time).

In reality, the mass media "effect" may be latent. Stanford University communication authority Dr. Wilbur Schramm comments:

${ }^{1}$ Zech $4: 6$ 
What if no response is observable at the moment? Can we assume that there has been no effect? Certainly not. The situation may not yet be ripe for action. Perhaps a change has taken place within the receiver that will show up when the time is right or when enough change has accumulated to cause action. 1

Ellen G. White states this concept with a spiritual applica-

tion:

The good seed may for a time lie unnoticed in a cold, selfish, worldly heart, giving no evidence that it has taken root; but afterward, as the Spirit of God breathes on the soul, the hidden seed springs up, and at last bears fruit to the glory of God. In our lifework we know not which shall prosper, this or that. This is not a question for us to settle. We are to do our work, and leave the results with God. ${ }^{2}$

White further points out that even when Jesus Christ was

on earth

Many hearts were moved that for a time made no sign. During the Saviour's life, His mission seemed to call forth little response of love from the priests and teachers; but after His ascension "a great company of the priests were obedient to the faith." 3

Nor did Christ's own disciples at first comprehend much of

His teaching,

- . and often His lessons seemed to be almost forgotten. But under the influence of the Holy Spirit these truths were afterward revived with distinctness, and through the disciples they were brought vividly before the new converts who were added to the church. 4

Clearly then, the success of one's seed sowing must not be evaluated by the success of one's reaping. Seed sowing should be evaluated on the extent and quality of the seed sowing-not on the

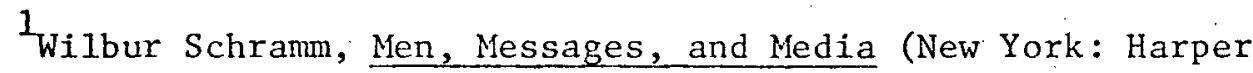
\& Row, Pub., 1973), p. 196.

2 White, Christ's object Lessons, p. 65.
$3_{\text {White, Evangelism, p. } 300 \text {. (Italics mine.) }}$
${ }^{4}$ White, Christ's Object Lessons, pp. 368-69. 
basis of how many plants have been harvested. The two operations, while purposefully related (one sows in order to reap), are distinct in nature.

For that reason, E1len White offers this counsel:

What if means are used and yet we cannot see that souls have been saved by it? What if there is a dead loss of a proportion of our means? Better work and keep at work than do nothing. You know not which sha11 prosper--this or that. 1

In fact, "eternity alone will reveal the results of welldirected efforts put forth now." 2 Even so, this much is certain: "He which soweth sparingly shall reap also sparingly; and he which soweth bountifully shall reap also bountifully." ${ }^{3}$ Indeed, "Blessed are ye that sow beside all waters." 4

Such was the work of Jesus. He did not confine Himself to one promising location. Rather He "broadcast" the seed to all the soil. Today radio broadcasting does just that. It recognizes no religious or cultural boundaries. Thus it provides a means whereby God can give "to all men liberally." 5 For that reason

There must be a totally new awareness of how completely the media presently dominate our lives, and their awesome potential for evangelism. Power, communication, and action are available if the church, under God's Spirit, takes hold of this remarkable field with vision and an aggressive spirit. ${ }^{6}$

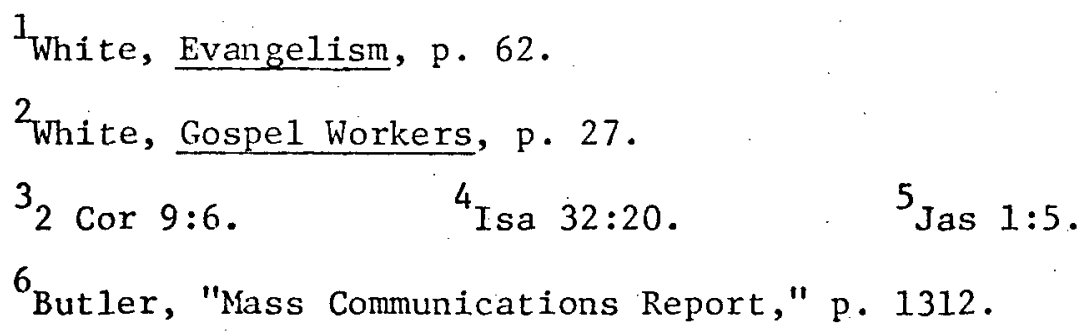


CHAPTER III

\section{A RATIONALE FOR RADIO SPOT EVANGELISM}

\section{The Context of Religious Radio Spots}

In his book Models of Religious Broadcasting, J. Harold Ellens categorizes all current religious broadcasting into four basic formats. They are: (1) "Preaching Format" (e.g., Bishop Fulton J. Sheen, Dr. Oswald Hoffman, Peter Eldersveld), (2) "Spectacular Format" (e.g., Billy Graham, Rex Humbard, Oral Roberts), (3) "Teaching Format". (e.g., William Fagal, M. R. DeHaan, Paul M. Stevens), and (4) "Spot Format" (e.g., Episcopalean Church, Mennonite Church, United Presbyterian Church, The Franciscans, Presbyterian Church U.S.). ${ }^{1}$.

Except for the "Spot Format," each of these formats have one thing in common. They each attempt to "sow the seed" at regular, or semi-regular, intervals and in lump sums.

In Christ's parable, however, the sower did not use such an approach. He did not bury his seed in strategic heaps. Rather, he cast it abroad--"by the wayside," "upon stony places," "among the thorns," and "into good ground."2

The word "broadcast," in fact, is derived and still applied

${ }^{1} \mathrm{~J}$. Harold Ellens, Models of Religious Broadcasting (Grand Rapids, Mich.: William B. Eerdmans Pub. Co., 1974), pp. 38-139.

2 Nit. 13:4-8. 
to this action of the sower: "A casting or scattering in all directions, as in sowing seed by hand." 1

Generally, most current religious program formats contradict this principle. Single programs are produced which radio stations air regularly at such undesirable times as Sunday morning or latenight sign-off. Of course, some limited good may result from such efforts. Yet the cumulative potential effect is greatly diminished, since it is generally known that few people are listening at those times.

The problem is compounded in that - . the "good news" proclaimed by the church is by no means itself always "pleasing," "interesting," or "entertaining," to the 1isteners. Yet, "pleasing," "interesting," and "entertaining" are three of the essential factors by which the broadcasting industry draws its listeners and viewers. ${ }^{2}$

of course, the Biblical reason for this is that "the natural man receiveth not the things of the Spirit of God: for they are foolishness unto him: neither can he know them, because they are spiritually discerned." 3

The net result is that, while most religious programs are aired at times when few people are listening, few of those who are listening to the radio at all are listening to religious programs.

\footnotetext{
1 Webster's New Collegiate Dictionary 1959 ed., s.v. "Broadcasting."

2 Edward Yih-Min Chenhwang, "Thematic Content Analysis As An Approach to Prediction of Audience Receptivity of Religious Radio Programs, With a Demographic Analysis of Program Preference: (Ph.D. dissertation, Michigan State University, 1974), pp. 36-37.

31 Cor $2: 14$.
} 
It is like putting all one's eggs in one basket and then hiding the basket.

A logical alternative is the radio "spot" (a presentation lasting sixty seconds or less). As will be noted, such an alternative approach may be--at present--among the best ways to incarnate the message of God's Word via radio. To better understand the significance of this approach, a brief understanding of the background and context for religious radio spots is warranted.

\section{Background of Religious Radio Spots}

Before the days of television radio was a "sit-down" form of home entertainment. Longer religious programs reached wider audiences than today. One reason for this was that fewer stations and fewer programs meant far less competition and, thus, larger "captive audiences" than today.

However, once television began to edge out radio as the dominant "sit-down" form of home entertainment, radio had to. do something to survive. That "something" was a shift in format emphasis from a basically foreground approach to a largely background approach. Television emphasized programs; radio emphasized music. In addition, as America became increasingly mobile and the pace of American lifestyles accelerated, fewer and fewer people listened to the radio for extended periods of time.

Thus emerged a tendency for "shorter and shorter programs." 1

${ }^{1}$ John W. Backman, The Church in the World of Radio-

Television (New York: Association Press, 1960), p. 117. 
What was fifteen minutes in length became five, and what was five became one. 1

Recognizing radio's shift in emphasis, advertisers began to sponsor fewer and fewer programs. Instead, they bought a minute here and a half minute there. News programs became shorter. Half-hour documentaries were split into segments, each lasting only two to three minutes apiece. Public service programs became public service announcements (PSA's).

Thus, the radio "spot" was born. Today

Spots have become part of the way of life of inillions of men, women and children. They are the advertising pages of the air waves, the billboards of the fascinating trip through prime time, the humor provided to drivers stymied by morning traffic and the hawker of a million products which, if all were used in quantity, should insure us of the most successful, most prestigious, most interesting, most rewarding... and on and on into the late night. 2

\section{Expeditious Rationale for Using}

Religious Radio Spots

Speaking to the need for greater coverage and penetration of religious radio messages, $M$. Sheldon LaVey, editor of Religious

Broadcasting Magazine, writes:

For years the problem of "reaching people where they are" has plagued the minds of broadcasters, pastors, and laymen who have seen all too well the success of advertising as it influences news media. It takes no great amount of research to show that a majority of today's population is generally not being exposed to the message of salvation. 3

As already implied, one reason why religious broadcasters

\section{$1_{\text {Ibid. }}$}

2M. LaVey Sheldon, "Spots," Religious Broadcasting, Apri1May, 1975, p. 11.

3 Ibid. 
have not been more successful in exposing larger segments of the population to the gospel is that most of them are still using yesterday's approach (i.e., foreground half-hour religous program for a "sit-down" audience) on a medium which has changed its style (i.e., background entertainment interspersed with short presentations and spots).

A further consideration is that that style change has largely conditioned the radio audience. Listeners now tune in stations instead of programs, and that usually for the specific type of music played. Their expectations are thus music oriented. Studies show that should the listener happen to tune in a religious progam in progress, most of them tend to turn the dial until they find.a station playing the type of music for which they had originally tuned in.

Thus, since radio stations cannot financially afford to lose listeners, most half-hour religious programs are either rejected or aired when most of the station's 1isteners are not listening. Obviously, the logical alternative is the religious spot. It goes where the listeners are-truly incarnating the Word among the masses. Thus, Charles Brackbill, Jr., formerly associate chairman of the Division of Mass Media of the United Presbyterian Church, states:

In the last couple of years, we have concentrated on spots because that is the way religious broadcasting must go to reach mass audiences. There are other things that you can do but you simply cannot get the mass audience with other kinds of programming. 1

${ }^{1}$ Charles Brackbill, Jr., quoted by J. Harold E1lens, "Thoughts on Spots," Religious Broadcasting, April-May, 1975, p. 15. 
What motivates his denomination to use spots is what motivates "all religious broadcasting agencies to do so: the desire to thrust a Christian message into the minds of the maximum of those not shaped by God's claims, and to do so with the highest efficiency at the lowest possible cost." 1

Essentially, radio spot evangelism is an attempt to use one's talents wisely. It is a decision that "thirty seconds of prime time" is "better than an hour in ghet to time," ${ }^{2}$ that "to say one provocative word in a way that sticks in the human mind is better than to have no chance at all to say many well-known words." 3

\section{Theological Rationale for Using Religious Radio Spots}

Theologically, the use of religious radio spots at different times during the broadcast day implies: (1) that Christianity is more than a once-a-week experience ${ }^{4}$, (2) that God is an every-day God, just as interested in man at 3:23 on Wednesday afternoon as He is at 11:01 on Sabbath morning ${ }^{5}$, (3) that God has something to say to man in the midst of his "secular" activities ${ }^{6}$; and (4) that man is daily dependent upon God for both his physical and spiritual bread. 7

Further, J. Harold Ellens points out that the use of the religious spot

- . depends on acceptance of a specific theological assumption. A spot is designed to startle a viewer or listener with an
$1_{\text {E11ens, p. } 133 .}$
${ }^{2}$ Ibid., p. 127 .
3 Ibid., p. 135 .
${ }^{4}$ Lam 3:23.
${ }^{5}$ Acts $17: 11$.
${ }^{6}$ Eccl $9: 10$.
7 Mt $6: 11$. 
idea, question, or issue. That will force him to think seriously and thus experience some growth in Christian concern, understanding, or action. The spot technique, therefore assumes that the business of inciting humans to responsible godliness can be accomplished by confronting man with God's claim. That, in turn, assumes God to be immanent in His world--the world of man-and capable of confronting man, at least vicariously. 1

In sum,

This theology takes God and man seriously. Its view of God is a high one: it sees Him as the rightful governor of man's existence and the immanent Divine presence, incarnated, as it were, in the human voice of the spot, redemptively addressing Himself to man, who is by implication, an agent capable of acting out God's claim and disciplining his decisions and actions in terms of godliness. 2

Virgil Megill takes Ellens" views one important step further, stating that religious radio spots tend to foster a relationship with Jesus Christ, which, says Megi11, "is promoting the highest type of thinking. ${ }^{3}$

The religious spot does more than present the fact of Jesus Christ, or the tragedy of evil. The spot presents a Christian alternative to human failure. The listener is encouraged to apply what he knows, to decide what is best, and to engage in problem-solving by a new relationship to Jesus Christ. ${ }^{4}$

Clearly, the Christian purpose for religious radio spots is

Biblical in nature.

Their technique is Biblically based as well. Such technique is illustrated by the Proverbs or the. Beatitudes, both of which are essentially self-contained messages. And both are very short forms

${ }^{1}$ E11ens, p. 125 .

${ }^{2}$ Ibid., pp. 125-26. (Italics mine.)

${ }^{3}$ Virgil Megill, "The Effective Spot," Religious Broadcasting, Apri1-May, 1975, p. 12 .

${ }^{4}$ Ibid. 
of communication. Additionally, it may be noted that the Twentythird Psalm can be said in forty-one seconds. ${ }^{1}$ Furthermore, most of Christ's parables could be spoken in one minute or less. And it should also be remembered that His parables were aimed largely at "unbelievers," ${ }^{2}$ the same target audience of most religious radio spots. Indeed, as Ellen G. White points out,

A few forcible remarks upon some point of doctrine will fasten it in the mind much more firmly than if such a mass of matter were presented that nothing lies out clear, and distinct in the minds of those ignorant of our faith. 3

She further states that if the evangelist's messages

are carefully considered before being presented to the people, if they are condensed and do not cover too much ground, if the Spirit of the Master goes with the utterances, no one will be left in darkness, no one will have cause to complain of being unfed. 4

of course, the religious radio spot producer must be aware of the potential danger of condensing the Christian message to a point of oversimplification where distortion of meaning may occur. Yet, as Edwin Epsy points out,

It is impossible for us to communicate the full gospel. Only Christ has manifested His fulness. Whenever we preach or teach the Word, or even when we administer the Sacraments, what we do is conditioned and partial. We communicate something of the Gospel, but we also impede it. ${ }^{5}$

$1_{\text {Bob Featherstone, "Spots: A New Opportunity," Religious }}$ Broadcasting, April-May, 1975, p. 18.

2

Mt $1.3: 10-17$.

3 White, Evangelism, pp. 171-72.

${ }^{4}$ Ibid., p. 175 .

${ }^{5}$ R. H. Edwin Epsy, in an address to the Mid-Winter Meeting of the Congregational Christian Churches, Buck Hill Falls, Penn., Feb. 4, 1959, quoted by Bachman, p. 123. 


\section{Therefore}

What we are called to do is to witness as we are given to witness, knowing our word--even over the air waves-has feet of clay; but speaking it with integrity, making sure that it exalts to the best of our finite ability Him whom we proclaim. This is 1 a matter of harmony, dimension, proportion, persepctive, balance.

Speaking to this matter of balance and proportion, John

Bachman draws the following insightful analogy:

A single molecule of water contains both hydrogen and oxygen in the same proportion as in a reservoir. Each fragment of the church's communicative attempt may retain the double character of the Word, the balance or tension between nature and grace, creation and redemption, transcedence and immanence. ${ }^{2}$

In sum, it may be observed that both the purpose and the technique of religious radio spots are Biblically-based. Yet, what does modern research reveal about this evangelistic technique?

\section{Research Support for Religious Radio Spots}

"Research has shown that spots do get the atttention of people and can stimulate thinking about man's relationship to God and to his fellow man." ${ }^{3}$. An example is the research conducted for the Mennonite Church.

An unprecedented use of promotional 30-second radio spots in religious broadcasting has brought one out of every four men in a predetermined age group in Terre Haute from a condition of ignorance to awareness of a selected Christian truth. The test campaign, sponsored by Mennonite Broadcasts, Inc., Harrisonburg, Va., has also shown that nearly one out of every two men remembered the radio messages and half of those could prove it. ${ }^{4}$

Research methodology included random telephone interviews

$1_{\text {Ibid. }}$

${ }^{2}$ Bachman, pp. 123-24.

3 E1lens, p. 129.

1975, p. 18.

4"Spots in Retrospect," Religious Broadcasting, April-May 
with three hundred Terre Haute men in an age group predetermined prior to the campaign. "Then a total of 110 half-minute spots created by the agency were broadcast each week over three radio stations for a nine-week period, beginning September 8, 1963."1 Afterward, three hundred other men in the predetermined age group was called.

Prior to the broadcasts, 43 percent were unaware of the basic Christian truth promoted by the spot. messages. Afterward, the figure was 32.9 percent. On a medium projection basis, the number of unaware. Terre Haute men between the ages of 18 and 40 dropped from 6,450 to 4,935. This is a reduction of approximately one out of every four who had formerly been unaware. 2

Three years later, in 1966, the United Presbyterian Church conducted "extensive research" in connection with their radio spot campaigns in Detroit, St. Louis, Toronto, and Columbus. ${ }^{3}$ In Detroit and St. Louis, "research showed that 99 percent of those who had heard the announcements got the message straight; moreover, 75 percent of those polled in Detroit and 79 percent in St. Louis said that the spots make them 'wonder about living with God." ${ }^{4}$ An official of the denomination said he considered the tests "wildly successful. $" 5$

Four years later, in 1970, David Charles Solt undertook "A Study of the Audience Profile for Religious Broadcasts in Onondaga County" for his Ph.D. dissertation at Syracuse Univeristy. His

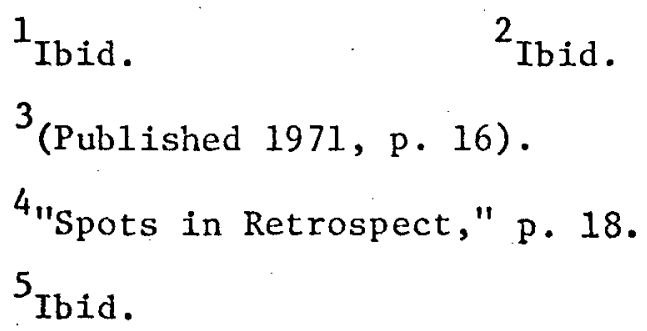


results indicated that, of those who could remember having heard either short religious radio announcements or religious discussion programs on current issues, by far the majority ( 67.5 percent) remembered hearing the spot announcements. 1

Empirical evidence of the effectiveness of religious radio spots may be seen in the church growth of the First Assembly of God Church in Winter Haven, Florida. In three and one-half years that church has grown from two hundred to two thousand members. ${ }^{2}$ The pastor of the church, Quinton Edwards, attributes the growth largely to his radio spot ministry.

I would say that my short radio broadcasts have been very influential in this church growth. At the same time, we have not simply promoted the church; we have promoted the Gospe1. The church promotion has been secondary. 3

In a similar experience, Seventh-day Adventist Pastor Tom Sanford firmly attributes the growth of his church in Shelby, Montana, to his daily sixty-second radio programs on KSEN. In one and one-half years his church grew in membership from under a dozen to over one hundred. Further, as a result of his influence and credibility resulting from the broadcasts, Sanford "was asked to help the area medical committee in their search for physicians." The outcome was that the medical committee offered the Toole county Hospital's operation to the Montana Conference of Seventh-day Adventists. The denomination accepted the offer. All of this resulted

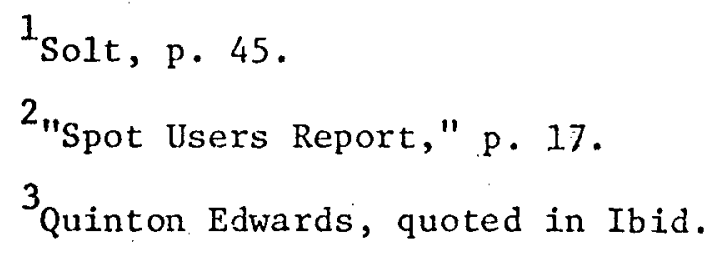


largely from "Pastor Tom's" daily sixty-second radio spots (aired at $7: 20$ a.m. and $11: 59$ a.m.)..$^{1}$

In Toronto, Ontario, Canada, the Kingsview Village Seventhday Adventist Church has doubled its membership in recent years.

The pastor of the church, D. J. Handysides, believes that his daily one-and two-minute broadcasts have contributed to that growth.

I would not say the radio has been a means of doubling my memvership. That can only be achieved by visitation, pastoral care, and by evangelistic work as we understand it. But I think that radio work has made a contribution and that when we visit with people they are not averse to what we have to say. I would certainly encourage other churches to engage in this kind of evangelistic project. I believe the more we are exposed as a people to the public the more chance we have of winning men and women to our wonderful message. 2

Handysides concludes that he is "convinced that we need more of these short, crisp, clean-cut, and truthful minute-sermons presented in a positive and powerful way." 3

$1_{\text {Tom Sanford, interview held at Andrews University, Berrien }}$ Springs, Mich., Sept. 17, 1975.

2Dan J. Handysides to James David Chase, October 19, 1972, p. 2 .

3 Dan J. Handysides, cited by Theda Kuester, "Radio Program Helps Growth in Church," Review and Herald, August 26, 1971, p. 19. 
CHAPTER IV

\section{FORMAT CONSIDERATIONS IN RELATED RESEARCH}

\section{The Need for Radio Format Research}

A primary concern of this project and "the crucial question we have to face is how to communicate the gospel to secular man."1 Since this paper defines "secular man" as one whose interests are primarily materialistic, most nominal Christians (persons in varying degrees of diminished spiritual interest, "having a form of godliness, but denying the power thereof ${ }^{2}$ ) and non-Christians may be appropriately categorized by this term.

Based on that assertion, and the sentiment expressed by Homrighausen that many broadcasters believe the secular man "cannot be reached by religion at all except through the mass media, " ${ }^{3}$ it appears that Solt is right when he suggests that "a more thorough study is needed of what makes certain types of programs more appealing to the less religious than others." 4

Such a study must necessarily include consideration of format type since, as Augsburger points out, "The message cannot be separated from the method which communicates it." 5 Indeed, any

${ }^{1}$ Fred Brown, Secular Evangelism (Gateshead, Great Britain: Northumberland Press, 1970), p. 11 .

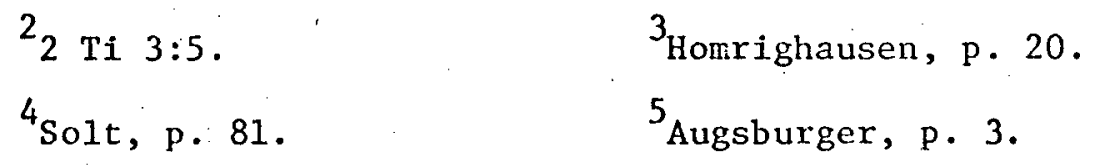


method or format becomes a language in itself, since it is a vehicle which conveys meaning in a particular way.

For that reason, Ellens notes that

Anyone with a product to sell is well aware of the importance of packaging. The same applies when one is promoting the Good News of the Christian gospel. The package may attract, or detract, or distract. 1

In fact, based on Robinson's research, "program format appeared to

be the most important single factor in attracting a wider audience

for religious programs, $" 2$ more important even "than the message itse1f. $"{ }^{3}$.

Additionally, when Robinson asked his respondents if they would be more likely to watch or listen to religious programs if they were presented in a different form, 4

almost half of the total sample felt that a change of format would cause them to listen more often. More important for the religious broadcaster is the observation that sixty-three percent of the "Irregular" listeners and thirty-five percent of "Non-1isteners" would appreciate a format change. 5

The following four sections of this chapter will deal with the four most common radio spot formats presently in use. of special interest are acceptability and credibility factors in these formats.

\section{The Straight Announcer Format}

In a "personal interview survey of 106 public service organizations," John Highlander discovered that "straight talk is

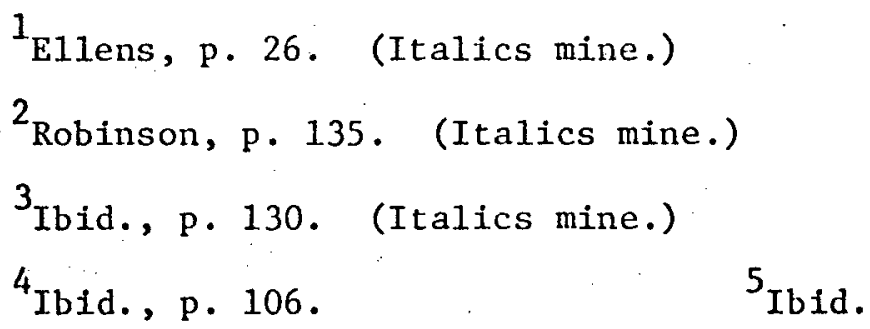


the most frequently used presentation type" ${ }^{1}$ of radio spot.

Traditionally, most religious radio programning has been of this type. ${ }^{2}$ Preachers simply went on the air and preached. Yet, Robinson found that the preaching format was generally the least we11 received of the dozen format types he studied. In fact, he found that preaching ranked "lowest in popularity for both the 'Irregular' and 'Non-1istener' groups," and "next to lowest for the 'Regular' listener group." ${ }^{3}$ His explanation is that, since radio is an informal medium, "a sermon preached directly at the listener is as out of place as a formal speech at a family dinner." 4

In another study, Willis investigated

the relative effectiveness of the straight talk, the complete dramatization, and the combined talk and dramatization in influencing attitudes. The straight talk was least effective in influencing the attitudes of high school students. The three forms of presentation were equally effective in influercing the attitudes of college students. Willis concluded that the form of presentation was not an important factor in programs designed to influence the attitudes of high school and college students.

Nevertheless, a later study by Pierce concludes that

A one-minute sustaining announcement--blended with adjacent program materials--promoting an unfamiliar intangible.item

${ }^{1}$ John Palmer Highlander, "Audience Measurements and Informational Effects of Speaker Variables in Radio Talks" (Ph.D. thesis, University of Wisconsin, 1953), p. 5.

2 Robert Charles Ringe, "An Analysis of Selected Personality and Behavioral Characteristics Which Affect Receptivity to Religious Broadcasting" (Ph.D. dissertation, Ohio State University, 1969), p. 12 .

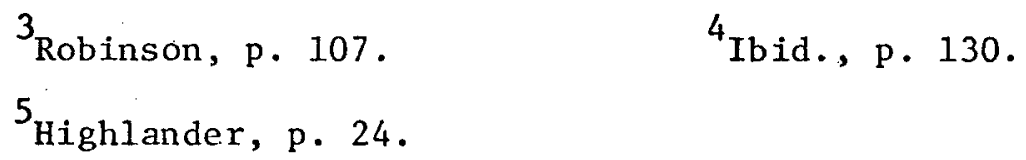


by a one-time straight reading is apparently the most durably effective radio announcement. 1

The apparent discrepancy between these findings may be at least partially accounted for by such intervening variables as the fact that neither study replicated the other, different phases of straight talk were studied, and different techniques employed. Yet, the differing results might also indicate that different forms of straight talk produce different results under differing conditions.

For that reason, a brief discussion of variables of "straight announcer" vocal delivery forms seems warranted.

Initially, it may be noted that the findings of Pierce indicate that "the skill of the announcer may increase the immediate effect of the commerical message but this effect diminishes and may be reversed after a period of time." 2

Regarding the announcer's manner of vocal delivery, Highlander cites "one of the earliest (1931) experimental studies on the radio speaker," conducted by R. M. Phillips at the University of Wisconsin. In sum, Phillips found that formal speeches were "more effective in the face-to-face situation while the informal speeches were more effective in the radio presentation. ${ }^{3}$

More recently (1973), Pearce

studied 521 undergraduates to determine the effect of vocalic communication on the persuasiveness of an oral message. . . .

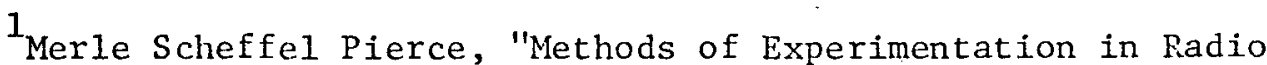
Reserach and Correlates of Effective Radio Advertising" (Ph.D. dissertation, University of Wisconsin, 1958); p. 61.

${ }^{2}$ Ibid., p. 71 .

3 Highlander, pp. 20-21. 
Results show that the speaker was considered more trustworthy, more favorably evaluated, and less dynamic when he spoke conversationally. . . A low credible introduction combined with a dynamic style was least effective, but a high credible introduction and dynamic style was judged most effective. It is concluded that style of delivery, interacting with initial credibility, is a factor contributing to the effectiveness of a message. 1

It should be noted, of course, that Pearce's study was conducted in a public-speaking situation. Nevertheless, his findings are of some pertinence to this project.

Bower's findings tend to coincide with Pearce's in terms of the credibility of conversational delivery. He found "that a highly intense persuasive speech was less effective in changing attitudes than a less intense one." 2

On the other hand, a study by Dietrich in which he "studied the relative effectiveness of the conversational and dynamic modes of delivery in influencing attitudes," concluded that "the differences in attitude change produced by both modes of delivery were so small that 'conscious effort of a radio speaker to employ the conversational mode may not pay dividends. $" 13$

At least three studies (University of Illinois, Highlander, and Lewis) have dealt with research related to the acceptability

$1_{W}$. Barnett Pearce, "Vocalic Communication in Persuasion" (Ph.D. dissertation, 1973), in Credibility, Psychological Abstracts. File, ed. Sylvai Deal (Research Triangle Park, N.C. 1976), p. 765.

2 James C. McCroskey and Walter H. Combs, "The Effects of the Use of Analogy on Attitude Change and Source Credibility," The Journal of Communication 19 (December 1969): 334 .

${ }^{3}$ John E. Dietrich, "The Relative Effectiveness of Two Modes of Radio Delivery in Influencing Attitudes" (Ph.D. dissertation, University of Wisconsin, 1945), n.p. 
and credibility of the content portion of the straight announcer format. $^{1}$ In essence, these studies conclude that, in terms of audience approval, the subject matter of a presentation is more important than the communicator of that subject matter.

In another study, McCrosky and Combs studied the subject matter of a presentation to ascertain, specifically, what effects two types of analogy might have on attitude change and source credibility.

Subjects were exposed to either a literal, figurative, or noanalogy message. Comparison of attitude change scores and terminal source credibility ratings by message condition indicated that both 1 titeral and figurative versions produced greater attitude change than the no-analogy version. Differences in source credibility ratings were not attributable to the use of analogy. 2

Ward studied the communicator's credibility in terms of when he is identified to the audience. His findings concur with several other studies which "have reported a tendency. for a communicator to be judged as more credible when he is identified after the persuasive communication than when identified before." 3

Finally, Ringe indicates that "the more persuasive a source

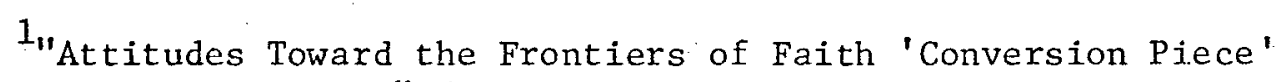
TV Series, June-July, 1958" (Mimeographed, University of Illinois: Institute of Communication Research, 1958), cited by Robinson, p. 8; Highlander, PP. 100-101; H. B. Lewis, "Studies in the Principles of Judgment and Attitudes: IV The Operation of 'Prestige Suggestion," Journal of Social Psychology 14 (1941): 229-56, cited by Cowdin, p. 254 .

${ }^{2}$ McCrosky and Combs, p. 333.

${ }^{3}$ Charles D. Ward, "Perception of Communicator's Credibility as a Function of When He is Identified" (Ph.D. dissertation, University of Maryland, 1974), cited by Deal, p. 759. 
is perceived as being, the less persuasive it will tend to be." 1

The Dialogue-Dramatization Format

Although Pierce found that "straight reading produces better retention," his findings also indicate that "dramatized radio announcements may have the most initial effect." 2

of significant additional interest, Robinson found that for "irregular" and "non-listeners" to religious radio programs (persons perhaps tending to be in the nominal and non-Christian category), those "formats which held the strongest appeal were those in which the message was given indirectly: for instance, religious drama, discussion or debate." ${ }^{3}$ He explains that "those who do not listen regularly to religion apparently feel that speakers on religious programs are dull and uninteresting. ${ }^{4}$

In another area of dialogue-format research, Kanungo found that a male-female pair of voices tend to create greater credibility for radio advertisements and results in greater liking for and intention to buy the advertised product. 5

Perhaps for reasons similar to these, Abbott concludes that "that straight commerical announcement no longer is so effective as the dramatized commerical." 6

$$
\begin{array}{ll}
1_{\text {Ringe, p. } 17 .} & { }^{2} \text { Pierce, p. } 71 . \\
{ }^{3} \text { Robinson, p. } 130 . & { }^{4} \text { Ibid., p. } 125 .
\end{array}
$$

${ }^{5}$ Rabindra N. Kanungo, "Effects of Slogans and Human Model Characteristics in Product Advertisements" (Ph.D. dissertation, McGill University, 1975), cited by Deal, p. 747.

${ }^{6}$ Waldo Abbott, Handbook of Broadcasting (New York: McGrawHill Co., 1950), p. 292, cited by Pierce, p. 16. 


\section{The On-the-Street Interview Format}

The on-the-street interview format consists of short, spontaneous opinions of randomly selected persons recorded in real life settings.

Guli briefly describes the historical impact of this format type (also commonly known as an "actuality"):

"The development of portable recording machines during World War II gave strong impetus to actuality broadcasts. Radio reporters descended with parachute troops, describing as they went. They joined bombing raids and interviewed troops on their reactions." 74 However, actuality material was used primarily in news programs; moreover, before the war, the Columbia Broadcasting System and the National Broadcasting Company had generally forbidden recorded spoken material in broadcasts of any type. Consequently, ip 1948, the technique was still fairly new to radio listeners.

${ }^{74}$ Erik Barnouw, Handbook of Radio Writing (Boston: Little Brown, and Co., 1947), p. 156.

Although the opinions of interviewees may tend to be more credible when attributed to persons holding "prestigious" positions, Guli points out that the interview may be more acceptable to an audience when any interviewee is more lucid. For example,

A public health nurse with a fund of human interest anecdotes, a warm personality, and a pleasant speaking voice may be better equipped to hold an audience than the president of the Chamber of Commerce, if he isn't a good speaker.

Guli's comments tend to be supported by Miller and Hewgill's research. They found "that as the number of nonfluencies presented

${ }^{1}$ Nancy Marion Guli, "A Victory in Persuasion: A Descriptive Analysis of the Radio Campaign Conducted by Columbia University in Association with the United States Public Health Service for the Nationwide Syphilis Case-Finding Drives of 1948-51" (Ed.D. dissertation, Columbia University, 1968), p. 170.

2 Ibid., p. 249 . 
by a speaker increases, audience ratings of the speaker will

decrease." 1

In sum, it appears that the value of the on-the-street interview format lies in the inherent credibility of its spontaneity.

Opinions become believable because they, apparently, are unrehearsed.

The Persona1-Experience Format

The personal-experience format typically consists of a person telling a personal experience he has had. This format differs from the "on-the-street interview" format in that it is experience oriented rather than opinion oriented.

Perhaps the most significant recent research in this area has been done by two psychologists at the University of Pittsburgh, Dr. John M. Levine and Dr. Ronald S. Va1le. Their findings are particularly pertinent to this project. Further, these men appear to have set a research precedent in the area of "the convert as a credible communicator," since

- . in spite of his ubiquitous presence in real-life persuasive settings, the convert communicator has so far eluded systematic investigation. Although some suggestive evidence for convert effectiveness can be gleaned from studies dealing with related source characteristics (e.g., Walster et al., 1956; Koeske and Crano, 1968), little or no specific research attention has been focused on the convert communicator (cf. Griffin, 1967; McGuire, 1969 ; Simons et a1., 1970). 2 .

${ }^{1}$ Gerald R. Miller and Murray A. Hewgill, "The Effects of Variations in Nonfluence and Audience Ratings of Source Credibility," The Quarterly Journal of Speech (February 1964): 36-37, cited by Arthur Ivan Boone, "The Influence of Voice Distinguishability on Source Credibility" (Ph.D. dissertation, Michigan State University, 1971), pp. 25-26.

${ }^{2}$ John M. Levine and Ronald S. Valle, "The Convert As a Credible Communicator," Social Behavior and Personality 3 (January 1975), p. 82 . 
The nature of Levine and Valle's research involved investiga-

tion into the

- - reactions to an anti-alcohol communication delivered by convert and non-convert communicators. In four convert conditions, the communicator was presented as a former alcoholic. The convert's communication was either Personal (first person pronouns) or Impersonal (third person pronouns). Compared with subjects current alcohol consumption, the convert's consumption at a consumption at a comparable time in life had been either Similar or Extreme. In a control condition (No Convert Impersonal), a life-long teetotaler presented a message identical with that given in the Impersonal Convert conditions. ${ }^{1}$

Because of the extreme significance of this study to the

present project, the essence of the findings of Levine and Valle

are quoted here verbatim:

Overall evaluations of the communicator and communication, as well as ratings of message persuasiveness were significantly more favorable in all four convert conditions than in the No Convert Impersona1, and in the Extreme than in the Similar conditions. ${ }^{2}$

The statistically significant comparisons can be summarized briefly. Compared with the No Convert Impersonal condition, in all four convert conditions the communicator was rated more Expert, Open, and Experienced, and in three convert conditions (except Similar Impersonal) the communicator was perceived as more Truthful. In the two Personal Convert conditions, the communicator was evaluated as more warm, and not surprisingly, the communication was rated more personal. In the two extreme Convert conditions, the communication was perceived as more Convincing, Powerful, and Concrete. Finally, in the Extreme Personal Convert condition, the communicator was seen as more Knowledgeable and the communication was rated more Fair. ${ }^{3}$

of additional pertinence to this project is the following rank ordering of mean ratings of message persuasiveness comparing the No Convert Impersonal condition with the four convert conditions.

$$
\begin{aligned}
& { }^{1} \text { Ibid., p. } 81 . \\
& { }^{3} \text { Ibid., p. } 87
\end{aligned}
$$


(Note: A low score indicates more favorable evaluation of message persuasiveness.)

Extreme Persona1 Convert . . . . 2.85

Similar Personal Convert . . . . 3.30

Extreme Impersonal Convert.. . 4.46

Similar Impersonal Convert . . . 5.33

No Convert Impersonal .. . . . $7.30^{1}$

In another recent study, James E. McCleaf researched The Effects of Students' Perceptions of a Speaker's Role on Their Recall of Drug Facts and Their Opinions and Attitudes About Drugs. In the experiment, involving 150 male and 150 female eighth graders, the subjects had a statistically significant (.05 level) interaction of recall of drug information when that information was presented by someone introduced as having been a user of drugs himself. ${ }^{2}$

The significance of these two studies for the format-. conscious Christian broadcaster cannot be underestimated. Personal experience generally means personal credibility. Thus, religious broadcasters Brackbill, Marty, and others conclude that the best religious radio spot is one in which someone is telling his own personal experience. 3

Thus Homrighausen writes, "More and more, we are realizing that the best evangelists are laymen who can speak to laymen where

$1_{\text {Ibid., p. } 86 .}$

${ }^{2}$ (Leanardtown, Md.: Board of Education of St. Mary's County, 1975), cited by Deal, p. 744 .

${ }^{3}$ Charles Brackbi11, Jr., in an interview with J. Harold Ellens, June 10, 1970, in "Thoughts on Spots," Religious Broadcasting 7 (April-May 1975): 15; Martin E. Marty, The Improper Opinion (Philadelphia: The Westminster Press, 1961), n.p., cited by Ringe, p. 17. 
they live in the vernacular which they understand."1

Jesus affirmed the credibility of one's personal experience

In his words to a man He freed from devil possession: "Go home to

thy friends, and tell them how great things the Lord hath done for

thee, and hath had compassion on thee." 2

John demonstrates this principle when he writes,

That which was from the beginning, which we have looked upon, and our hands have handled of the Word of Life;. . . that which we have seen and heard declare we unto you, that ye also may have fellowship with us: and truly our fellowship is with the Father and with His Son Jesus Christ. 3

Ellen White speaks of the credible effectiveness of relating

one's personal experience:

Our confession of His faithfulness is Heaven's chosen agency for revealing Christ to the world. We are to acknowledge His grace as made known through the holy men of old, but that which will be most effectual is the testimony of our own experience. 4

Perhaps this is because the persuasion of personal experi-

ence is the persuasion of results. People identify with people more readily than with ideas. This identification is essentially vicarious participation. When a listener thus "experiences" the communication of a Christian's personal peace and satisfaction, he apparently tends to be motivated to know more.

Thus, the persuasion of witness precedes the persuasion of ideas. The persuasion of witness, in fact, credibilizes the persuasion of ideas. For this reason, Ellen white suggests that

${ }^{1}$ Homrighausen, p. 22 .

${ }^{2}$ Mk $5: 19$. 31 Jn $1: 1,3$

${ }^{4}$ Ellen G. White, The Desire of Ages (Mountain View, Calif.: Pacific Press Pub. Assn., 1940), p. 347. (Italics mine.) 
As witnesses for Christ, we are to tell what we know, what we ourselves have seen and heard and felt. If we have been following Jesus step by step, we shall have something right to the point to tell concerning the way in which He has led us. We can tell how we have tested His promise, and found the promise true. We can bear witness to what we have known of the grace of Christ. This is the witness for which our Lord calls, and for the want of which the world is perishing.

A recent (1977) study by the Bloom Advertising Agency confirms the market for this type of religious radio Spot. Bloom, hired by the Baptist General Convention of Texas, tested a "variety of uplifting TV commercials." The "runaway favorite" was someone telling a personal experience he had had. "So Bloom settled on a series of 'witness-bearing' ads designed to show--in 30 seconds--that Christ could change people's Iives." ${ }^{2}$

In the last week of February 1977, the Convention launched a $\$ 2$ million campaign called "Good News Texas" based on this research. For two months, Texas radio and IV 1isteners heard revolutionary Black Panther leader Eldridge Cleaver, country-music singer Jeannie C. Riley, Houston Oiler star Billy (White Shoes) Johnson, and business executive Allan Mayer of the hot-dog Oscar Mayers "proclaim their faith in filmed TV spots accompanying such prime-time fare as 'The Boinic Woman' and 'Sonny and Cher. ${ }^{113}$

In addition to prime time $\mathrm{TV}$ spots, the Baptists also used "saturation radio commericals, newspaper ads, miles of highway billboards and a thicket of posters, as well as follow-up phone calls,

${ }^{1}$ Ibid., p. 340 .

2 Margaret Montagno and Janet Huck, "The Selling of Jesus," Newsweek, February 29, 1977, p. 49.

$3_{\text {Ibid., p. } 48 .}$ 
letters, and visits." 1 By the time the campaign ended, the Baptists predicted that "every man, woman, and child" in Texas ". . got the good news--one way or another--at least 40 times. $" 2$

\section{Summary}

This chapter has been an attempt to show the importance of religious radio spot formats. Particular attention has been devoted to research related to acceptability and credibility factors of these formats.

Each of the four formats studied has been shown to have a degree of listener-perceived acceptability and credibility.

The following chapters will report the procedures and results of the present study of these formats in terms of listener-perceived acceptability and credibility factors for the nominal and nonChristian.

$1_{\text {Ibid. }}$

${ }^{2}$ Ibid., pp. 48-49. 
CHAPTER V

\section{DESCRIPTION OF SURVEY PROCEDURES}

\section{Introduction}

This chapter includes (1) definition of terms used in this project report, (2) description of the development of the survey instrument used in this project, (3) rationale for survey questions, and (4) description of the implementation of the survey itself.

\section{Definition of Terms}

Frame. A frame is composed only of those respondents whose characteristics are unique to the survey objective. In this case, the frame includes only those persons in the nominal and nonChristian categories, as indicated by a score of 3 or less on the attitudinal scale of the survey instrument. (A rationale for this indicator is discussed later in this chapter).

Nomina1 Christian. A nonpracticing Christian; one who believes in Christianity, giving mental assent to the value of such practices as church attendance, prayer, and study of the Scriptures, but who rarely, if ever, puts these beliefs into practice. The Bible describes such persons as "having a form of godliness, but denying the power thereof" ${ }^{1}$; and again, "This people draweth nigh

${ }^{1} 1$ Tim $3: 5$. 
unto Me with their mouth, and honoreth Me with their lips; but their heart is far from Me."I

Non-Christian. A person who does not claim to be a Christian. Although such a person may or may not be a member of a religion other than Christianity, this project more narrowly defines him as one whose life orientation is basically secular and materialistic.

Radio Spot. A radio broadcast lasting sixty seconds or less. Survey Instrument. A printed listing of questions to be asked of those in the frame. In this case, the survey instrument is a two-page listing of twelve questions to be asked of all persons in the nominal and non-Christian categories.

\section{Development of the Survey Instrument}

In order to eliminate as much bias as possible from the survey, the researcher conducted seven sessions of on-the-street interviews, involving 386 persons in the Benton Harbor-St. Joseph area. The purpose of the interviews was twofold: (1) to provide the researcher with creative ideas for specific questions to be included in the survey instrument and (2) to refine word choices and sentence structures to clarify intended meanings where necessary.

In addition, twenty-one Andrews University faculty members (whose research opinions were considered significant to this study) were sent copies of a preliminary draft of the survey instrument. Their responses were carefully considered, resulting in further refinement of the survey instrument.

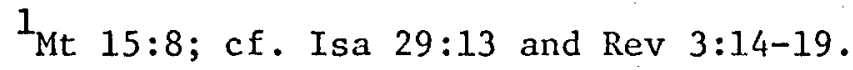


The Seven On-the-Street Interview Sessions

The following is a brief description of the seven on-thestreet interview sessions:

(1) Interview session of June 22, 1976. Fifty-one persons were contacted between 2:45 p.m. and 5:00 p.m. at Fairplain Plaza, Benton Harbor. Respondents were asked to state what they liked and/or did not like about religious radio spots. Their comments were tape recorded. The next day, the recorded comments were synthesized on paper by subjective content analysis. (See appendix A.)

(2) Interview session of June 29, 1976. One hundred persons were contacted in a four-block downtown area of St. Joseph, and in Fairplain Plaza, Benton Harbor. Respondents were asked a series of three questions using an attitudinal scale. The purpose of the questions was (a) to ascertain respondents' understanding of what attributes characterize persons in the nominal and non-christian categories and (b) to test their understanding of the term "nonpracticing Christian." Generally, it was found that respondents did not understand the meaning of the term "nonpracticing Christian," and had difficulty comprehending what was really being measured. (See appendix B.)

(3) Interview sessions of July 13-14, 1976. One hundred and twenty-five were contacted in the same previously mentioned areas of St. Joseph and Benton Harbor. Respondents were asked to answer three questions on a numbered attitudinal scale. The first two questions were simply "warm up" questions designed to "set up" the respondent to answer the third question with as much freedom from survey bias as possible. This third question was critical to the 
development of the first portion of the survey instrument, in that it provided an indication of which specific numbers on the attitudinal scale $\left(\begin{array}{lllllll}0 & 1 & 2 & 3 & 4 & 5\end{array}\right.$; where $0=$ no interest in Christianity and 5 = highest possible interest in Christianity) were perceived by the respondents to be illustrative of one who believes in Christianity, but who does not practice what he believes. Since that type of person may be thought of as a nonpracticing Christian, and since this project defines a nonpracticing Christian, as a nominal Christian, an important reference point on the attitudinal scale was arrived at.

The results were these: two of the three measures of central tendency (the median and the mode) clearly indicated that persons in the nominal or "nonpracticing" Christian category might be best described by numbers 3 and below on the attitudinal scale $\begin{array}{llll}0 & 1 & 2 & 3\end{array}$ 45 ). Additionally, the mean score was 2.832 , strongly pointing to number 3 as the cut-off reference point on the scale for those in the nominal and non-Christian categories.

of course, the importance of ascertaining this cut-off reference point lay in the need to determine which persons were in the nominal and non-Christian categories so that their opinions might be surveyed and so that those not in those categories might be systematically eliminated from the frame. (See appendix C.)

(4) Interview session of July 20, 1976. Thirty persons were contacted in the same previously mentioned areas of St. Joseph and Benton Harbor. Respondents were asked a personalized version of the July 13-14 interview questions (a) to help refine word choices and sentence structures to clarify intended meanings, and (b) to 
roughly estimate how many persons would ultimately need to be contacted in order to arrive at the statistically significant (less than .1 leve1) number of three hundred nominal and non-Christians needed in the frame. At that time it was projected that nine hundred persons would need to be contacted in order to achieve the needed minimum of three hundred nominal and non-Christians. This projection was shown to be accurate. (See appendix D.)

(5) Interview session of July 23, 1976. Thirty persons were contacted in the same previously mentioned areas of St. Joseph and Benton Harbor. In addition to those questions asked previously on July 20, respondents were asked a combination of open-ended and multiple-choice questions to help determine the "validity" of the questions and to refine a format structure for the second part of the survey. (See appendix E.)

(6) Interview session of September 2, 1976. Thirty persons were contacted in the same previously mentioned areas of St. Joseph and Benton Harbor. Respondents were asked to choose which one of four radio spot formats appealed to them most and to explain what was meant by each format description. In this way, the researcher discovered which format descriptions were ambiguous to certain respondents and which were understood correctly. (See appendix F.)

(7) Interview session of September 13, 1976. Twenty persons were contacted in the same previously mentioned areas of St. Joseph and Benton Harbor. Respondents were asked to define certain terms and phrases used in the survey instrument. In this way, the researcher discovered which terms and phrases were ambiguous to certain respondents and which were understood correctly. (See appendix G.) 
Survey Instrument Evaluations of Andrews

University Faculty Members

On September 11, 1976, a preliminary draft of the survey instrument was sent to twenty-one Andrews University faculty members seeking their constructive suggestions. (See appendix $\mathrm{H}$ and appendix I.) Sixteen of these faculty members responded. Their comments and constructive criticism were carefully considered and tabulated in summary form on a copy of the survey instrument. A further refinement of the survey instrument resulted from this effort.

\section{Rationale for Survey Questions}

\section{Introduction}

Hello. I am from Andrews University. We are doing a brief radio survey today. And I need your help with a few questions on radio listener preferences to help us improve our broadcasts, okay? It will only take a few minutes and I will be very grateful.

The introduction to the phone interview was carefully worded to be as credible, motivated, and concise as possible.

Possible credibility factors included (1) use of interviewer's full name, (2) use of "Andrews University" as the origin of the survey, (3) use of the pronouns "we," "us," and "our" correctly implying that the survey would benefit more persons than simply the interviwer, and (4) a statement describing the purpose and intended use of the survey results.

Possible motivation factors included (1) an altruistic appeal in the words "I need your help... to help us improve. . . I will be very grateful" and (2) the fact that the survey was to be "brief," "take only a few minutes," and only involved "a few questions."

A conscious attempt was made to keep the introduction as con- 
cise as possible. Only four brief sentences were used. Also, the term "radio listener preferences" was left intentionally vague in order to accommodate the differing objectives of the first three questions and the last nine questions. (The term was never questioned by any of the persons called.)

\section{First set of instructions}

Picture in your mind a row of numbers from zero to five. And let us call that row of numbers a scale, okay? Zero means that you do not do whatever is being asked about. Five means that you do it all the time. Do you understand?

The objective of the first set of instructions was to convey to the respondent the manner in which he was to answer the first three questions.

To facilitate that objective, the respondent was asked to be a participant--rather than a spectator--in the receiving of the instructions. He was asked to "picture" something ("a row of numbers from zero to five") in his mind. This mental action was immediately clarified by defining the "row of numbers" as a "scale." The rationale was that some persons might not have understood the meaning of the term "scale" without this visualized definition.

The respondent was then informed of the meaning of the numbers on the opposite extremes ( 0 and 5 ) of the scale.

It should be noted that the respondents were not simply asked their opinion of the actions suggested in the first three questions. Rather, they were asked about their own personal practice of the actions suggested.

The final sentence in the first set of instructions ("Do you understand?") was simply designed to assist the interviewer in 
clarifying, where necessary, the instructions to the respondent. In actual practice, it was discovered that this clarification was most easily accomplished by simply "giving question number one a try."

\section{Questions One through Three}

\section{Questions 1 and 2}

Which number on the scale of 0 to 5 would you honestly pick to show how much you actually attend sporting events. 0 means you do not attend sporting events. 5 means you attend sporting events as often as possible.

Which number on the scale of 0 to 5 would you honestly pick to show how much you actually wear seat belts every time you drive. 0 means you never wear seat belts. 5 means you always wear seat belts.

These first two questions were designed to "set up" the respondent to answer question 3 with as much freedom from bias as possible. The questions were very carefully worded to encourage honesty and forthrightness on the part of the respondent. For that reason the words "honestly" and "actually" were consciously included in the questions. Thereby, it was hoped that once the respondent had become accustomed to the parallel terminology of the questions that these two words would not imply to him any possible distrust of his answer to the question of his own religious practices. Further, it was hoped that the inclusion of these two words would tend toward making the respondent's answers more accurate and reliable.

These first two questions were secular in nature. The first dealt with a pleasure activity; the second dealt with a safety activity.

It should also be noted that these first three questions are 
sequentially ordered in terms of what was thought to be relative difficulty of self-disclosure. The first question was easy to answer. The respondent was simply asked how much of a sports spectator he was. The second question was slightly more difficult in that it was more personal in nature. The respondent was asked how often he wore seat belts while driving. The third question was, perhaps, the most difficult to answer in that more self-disclosure was called for than in the previous questions, both in terms of quantity ("church attendance, prayer, and study.of the Scriptures") and quality (forthrightness and honesty).

Since it was thought that there was no pertinent correlation between the first two questions and the remainder of the survey, no answers were recorded for these two questions.

\section{Question 3}

Which number on the scale of 0 to 5 would you honestly pick to show how much you actually put Christian beliefs into practice, such as regular church attendance, prayer, and study of the Scriptures. 0 means that you do not put Christian beliefs into practice. 5 means that you always put Christian beliefs into practice.

This was the most critical question in the survey. On the basis of the respondent's answer to this question, the interviewer either continued the interview or thanked the respondent and hung up. If the respondent answered 3 or any number below 3 , the interviewer continued the survey questioning. In such case, the interviewer knew that he was then talking to someone whose answer indicated that he was in the nominal and non-Christian categories. If, however, the respondent answered 4 or 5 , the interviewer knew he was talking to someone who perceived himself to be a practicing 
Christian. In this case, the interviewer discontinued his questioning, since, of course, only "nonpracticing" Christians and nonChristians were to be included in the survey frame.

Both external and internal indicators were used to determine those who were nominal or non-Christians. The external indicator was "church attendance." The two internal indicators were "prayer and study of the Scriptures." These three indicators were used only as examples of certain practices of Christians. Respondents answered according to their relative degree of active participation in such Christian practices as these.

It is impossible, of course, to know with absolute certainty the accuracy of the respondent's answers. His own personal biases, as well as biases inherent in the answering of survey questions, make it difficult for the researcher to arrive at pure fact. Nevertheless, it should be remembered that the survey technique itself freely admits to the vulnerability of independent variables and statistical error.

The point is this. God alone is fully capable of knowing a person's true spiritual condition, since "man looketh on the outward appearance, but the Lord looketh on the heart." 1 Under these circumstances, therefore, the best that can be done is to evaluate respondents on the basis of their own perceptions of themselves.

of course, a respondent's own perceptions of himself may be faulty. He may misunderstand the question or feel threatened by it. He may even misanswer the questions intentionally or unintentionally.

${ }^{1}$ Sam $16: 7$ 
Nevertheless, the researcher's only source of evaluation is the respondent's answer. For that reason, each question must be phrased and worded with great care.

Thus it was felt that a numbered scale (instead of the "semantic differential" scale) would tend to produce less bias, since numbers are more denotative, words (e.g., none, rarely, sometimes, often, and always) are more connotative, relative, and potentially ambiguous. Additionally, use of the number scale may have freed respondents to express with greater forthrightness their true perceptions of their own religious practice.

The intrinsic validity of the scale lies to some extent in the assumed probability that active, practicing Christians will tend to rate themselves high ( 4 or 5 ) on the scale, and nonpracticing Christians will tend to rate themselves lower ( 3 and below) on the scale. In fact, it does not seem probable that a truly active, practicing Christian would tend to rate hinself lower on the scale than a 4 or 5 (though this may be the case in some isolated instances).

Actually, it would seem more probably that bias might show up in the case of someone who believes in Christianity, but who does not put his beliefs into practice. Such a person, perhaps in a desire to "look good" and be "well thought of" by the interviewer, might tend to respond using a higher number on the scale than he should. Such a person, answering either 4 or 5 , would be automatically eliminated from the frame.

Thus, the researcher is relatively assured that those who do answer in the 3-and-below area of the scale are truly in the 
nominal and non-Christian categories. The researcher is, in fact, glad that any dishonest nominal and non-Christians have eliminated themselves from the frame, since their answers to other questions also might be false representations.

\section{Second set of instructions}

Now, besides commercials, radio stations play one minute presentations from nonprofit organizations. The last few questions deal with this kind of one-minute presentation. Since each question is multiple choice, you simple tell me which answer you prefer.

The objective of the second set of instructions was to convey to the respondent the manner in which he was to answer the last nine questions of the survey. As such, the instructions were transitional in nature, indicating a shift from the numbered-scale approach to the multiple-choice approach in answering.

Again, considerable care was taken to insure that the words used in the instructions conveyed their intended meaning. For example, since prior survey-instrument research indicated that a majority of those interviewed did not understand the term "radio spot," and most attached negative "selling gimickry" connotations to the term "commercial," neither of these terms was used in the instruction or the questions of the survey instrument. Instead, it was discovered that the phrase "one minute presentation from a nonprofit organization" did accurately convey intended meaning. Using that phrase, the respondent was informed that all of the following questions dealt with that area of broadcasting. 
Questions Four through Nine

Initially, it should be noted that questions 4 and 5,6 and 7, 8 and 9 are three sets of questions dealing with three areas of religious radio spot formatting of primary interest to this project. The three areas are: (1) the use or nonuse of music in the spot, (2) the four basic radio spot formats currently in use, and (3) the type of person identified in the spot as the originator of the message of the spot.

Since a major objective of the project was "to discover which of the most commonly used radio production formats contribute most to credibility and acceptability of religious radio spots whose intended audience is either nominal or non-Christian," the first question of each two-question set dealt with acceptability; the second question dealt with credibility.

In this respect, all questions were parallel in their terminology. Acceptability was implied in the phrase "most inclined to listen to." Credibility was implied in the phrase "sounds the most believable to you."

Except for the demographic information questions (10, 11, 12), each question included the option: "It makes no difference." This option was to be marked only if the respondent himself answered in this specific way. Otherwise, it was not intended to be read as a part of any question. The reason for this was simply to reduce survey answer bias, since the reading of this option might tend to predispose a respondent to avoid careful consideration of the primary options being surveyed. The logical assumption was that it is easier for a respondent to simply answer "It makes no difference" 
than to make the effort to evaluate and decide on one of the primary options of each question.

\section{Questions 4 and 5}

Generally, are you more inclined to listen to a one-minute radio presentation...

(1) With music. . or . .

(2) Without music

(3) It makes no difference

Generally, which type of one-minute radio presentation sounds the most believable to you . .

(1) With music. . or . .

(2) Without music

(3) It makes no difference

The basis for these two questions lies in what appears to be a growing trend for realism in broadcast advertising. For example, some advertisers now prefer radio announcers to speak candidly from product fact sheets than to read carefully planned scripts. Other advertisers prefer on-the-spot interviews with customers. In many cases, 1ittle or no music is used in these spots.

The rationale is simple. The advertiser does not want to sound "slick" or "gimicky." He does not want to sound "national." Instead, he wants to sound "local," neighborly, and friendly.

Questions 4 and 5 grew out of this awareness. Since the researcher knows of no study dealing with the effects of music on the acceptability and credibility of radio spots, he was particularIy interested in questioning his respondents in this area. (Of course, it is recognized that many types of music are used in many different ways in radio spots.)

of particular interest in this area was any difference which might show up between acceptability and credibility factors. 
Specifically, was the type of spot (with or without music) which respondents were "more inclined to 1isten to" also perceived by them to be more "believable"?

Questions 6 and 7

Generally, which one of the following types of one-minute radio presentations are you most inclined to listen to . . .

(1) Announcer reading the script

(2) Two people talking to each other

(3) On-the-street interviews

(4) Someone telling a personal experience he has had

(5) It makes no difference

Generally, which one of those types of one-minute radio presentations sounds the most believable to you ...

(1) Announcer reading the script

(2) Two people talking to each other

(3) On-the-street interviews

(4) Someone telling a personal experience he has had

(5) It makes no difference

These two questions were the heart of the survey. They dealt with the four most commonly used radio spot formats in use today.

The objective of these questions was to determine which formats contributed most to acceptability and credibility of oneminute radio spots for the intended audience. Largely on the basis of respondents' answers to these questions, a thirteen-week series of daily radio spots was to be produced as a part of this project.

For that reason, many hours of interview research went into the selection of terms and phrases for these questions. In this regard, the researcher had a twofold objective in the wording of the questions. First, he sought for clarity of meaning. Second, he sought for brevity of phrasing to help the respondent comprehend, compare, and decide with greater ease on one of the format options. While the researcher was vitally interested in the 
statistical interval comparisons between the four format options, he, nevertheless, chose to employ an ordinal (i.e., multiple-choice) scale of measurement for these questions.

One reason for this was to allow the respondents to make a clear-cut choice between different formats, instead of evaluating (by use of a numbered or semantic differential scale) each format independent of the others. An apparent strength of this type of measurement is that the respondent is able to make a decision in an enlarged contextual framework. That is, instead of evaluating each format one-at-a-time, by using the ordinal scale of measurement he has other reference points (in this case, other format options) to aid him in making possibly a better analytical decision than otherwise. Thus, his answer is more contextually oriented.

Another strength of the ordinal scale of measurement, in this instance, is that it is less time consuming. That, of course, is an important consideration in conducting telephone interviews. For while a respondent might willingly consent to answer two questions in multiple-choice fashion, he might be more reticent to answer eight questions designed to accomplish the same end. In fact, his latter responses might be less reliable because of a desire to quick1y terminate the interview.

Nevertheless, the researcher does recognize that under appropriate circumstances (e.g., mail surveys, personal-interview surveys) the interval scale of measurement has certain advantages. One major advantage is the possibility for a more precise attitudinal analysis of independent and, by comparison, collective responses to questions. 
Questions 8 and 9

Generally, which one of the following types of one-minute radio presentations might you be most inclined to listen to . . .

(1) A commentator discussing Christianity

(2) A pastor explaining Christianity . . . or . . .

(3) Any Christian telling why he is one

(4) It makes no difference

Generally, which one of those types of one-minute radio presentations sounds the most believable to you .'.'.

(1) A commentator discussing Christianity

(2) A pastor explaining Christianity

(3) Any Christian telling why he is one

(4) It makes no difference

The objective of this set of questions originated in the supposition that certain types of communicators are more acceptable and credible than others to certain audiences.

Depending on the findings of questions 6 and 7 , therefore, the researcher was interested to discover which type of communicator was generally prefered by those in the nominal and non-Christian categories. For example, if it was found that "Announcer reading the script" was generally perceived to be the most acceptable and/or credible format type, just how should the "announcer" be introduced in order to be most acceptable and credible to his audience?

Because these two questions dealt overtly with Christianity, and since those answering the questions admitted to being in the nominal and non-Christian categories, this set of questions was placed last in the series to lessen any possible prejudice on the part of the respondents.

\section{Questions Ten through Twelve}

The last three questions in the survey were demographic in nature. Their purpose was to further define which answer 
preferences might be attributable to which specific respondent categories. Since the researcher was interested in demographic information only in the areas of age, race, and sex, only these categories were included in the survey.

\section{Question 10}

Could you tell me which of the following are categories you are in, please...

(1) Below 18

(2) 18 to 34

(3) 35 to 65

(4) Above 65

The objective of this question was to discover any differences in respondents' answers on the basis of age.

The age categories were selected largely on the basis of age categories commonly used in broadcast marketing research.

\section{Question 11}

Could you tell me which of the following races you represent, please . .
(1) White
(2) Black
(3) Spanish
(4) Other

The objective of this question was to discover any differences in respondents' answers on the basis of race.

The race categories were selected based on a knowledge that these races dominated the area surveyed.

\section{Question 12}

Sex . .
(1) Male
(2) Female 
The objective of this question was to discover any differences in respondents' answers on the basis of sex.

\section{Implementation of the Study}

After careful refinement of the survey instrument, 950 copies were printed on $0 \mathrm{p}-\mathrm{scan}$ computer forms at the Andrews University Computing Center. This part of the project, involving two printings, was directed by Ruth Ann Plue.

The most recent edition of the Michigan Be11 Telephone Directory was used in the generation of numbers to be called. ${ }^{1}$ Conveniently, there were exactly one hundred pages in the white-pages section of the phone book. Therefore, to generate nine hundred phone numbers simply involved a random selection of nine numbers (three per column) for each page in the phone book.

These numbers were selected using a Table of Random Numbers in Glass and Stanley's Statistical Methods in Education and Psychol으y.

Nine numbers were selected. These same nine numbers were used on each page in the phone book. When, however, the number listed was a phone number either outside the survey area or for a business, the next eligible phone number down on the page was selected to be called.

1 Michigan Be11 Telephone Directory: Benton Harbor-St. Joseph Area, 1976-77 (Detroit, Mich.: Michigan Bell Telephone Co., issued October 1976).

2 Gene V. Glass and Julian C. Stanley, Statistical Methods in Education and Psychology (Englewood Cliffs, N.J.: Prentice-Hall, 1970), pp. 510-12. 
The researcher was assisted in the actual calling of interviewees by Betty Lou Hartlein. Mrs. Hartlein has had extensive telephone interview experience working for the Education Department of Andrews University. She conducted approximately half of the telephone interviews for this survey. The other half of the interviews was conducted by the researcher himself.

In a three-month period, ending February 20, 1977, nine hundred different phone numbers were called. of this number, 724 were actually surveyed. There were 176 unusable phone numbers, primarily because no one answered the phone or the phone had been disconnected. Except in the instances where the phone had been disconnected, these 176 phone numbers were called at least five times at different times on different days of the week. Each time, the phone was allowed to ring a minimum of four, and more often, five times. A1so, 413 persons eliminated themselves from the survey when they indicated by a 4 or 5 answer to question 3 that they were in the practicing Christian category.

Therefore, 311 persons, who indicated by a 3,2, 1, or 0 answer to question 3 that they were in the nominal and non-christain range of categories, were included in the survey frame. This figure (311) met the criterion for statistically significant survey results (at the less than .1 level). The computation for this figure was based on the formula:

$$
\mathbf{s}=x^{2} N p(1-p) \div d^{2}(N-1) \div x^{2} p(1-p)
$$

where

$$
\begin{aligned}
x^{2}= & \text { Chi-square for } 1 \text { degree of freedom } \\
& \text { at the desired level of confidence }
\end{aligned}
$$




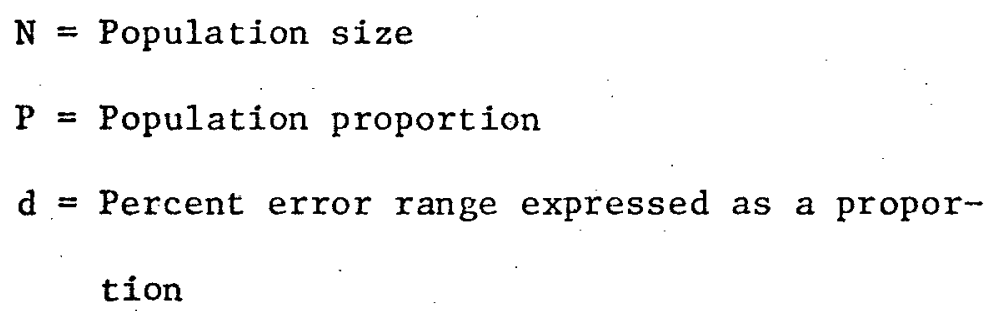

This formula was provided by the National Education Association, and cited by Krejcie and Morgan. ${ }^{1}$

${ }^{1}$ Robert V. Krejcie and Daryle Morgan, "Determining Sample Size for Research Activities," Educational and Psychological Measurement 30 (Autumn 1970): 607-10. 
CHAPTER VI

RESULTS OF THE SURVEY

\section{Introduction}

A primary objective of this project was to discover which of the most commonly used radio production formats contribute most to acceptability and credibility of religious radio spots whose intended audience is either nonimal or non-Christian.

To accomplish that goal, 311 persons--indicating by a 3 or below answer on a numbered scale $\left(\begin{array}{llllll}0 & 1 & 2 & 3 & 4 & 5\end{array}\right)$ that they were either nominal or non-Christians--were surveyed by phone in the Benton Harbor-St. Joseph, Michigan area. In the following pages the data gathered from the survey is presented and subjectively interpreted on the basis of frequencies and percentages.

\section{Overview of Demographic Findings}

As tables 1 through 5 show, the largest number of respondents in the frame were white, female, age 18-34, living in Benton Harbor, and had a 3-nominal Christian rating on the numbered scale.

TABLE 1

RACES OF THE RESPONDENTS

\begin{tabular}{|c|c|c|c|c|c|c|c|c|c|c|}
\hline Races & & & & & & & & & $\mathrm{N}$ & $\%$ \\
\hline White & . . & . & . . & • & - . & - & • & & 259 & 83.28 \\
\hline Black . & - . & • & . . & - & $\cdot \cdot$ & $\cdot$ & • & & 49 & 15.76 \\
\hline Spanish & . . & - & . . & - & . . & • & $\cdot$ & & 1 & .32 \\
\hline Other. & $\cdot$ & - & - . & . & ${ }_{76}$ & $\cdot$ & . & & 2 & .64 \\
\hline
\end{tabular}


TABLE 2

SEX OF THE RESPONDENTS

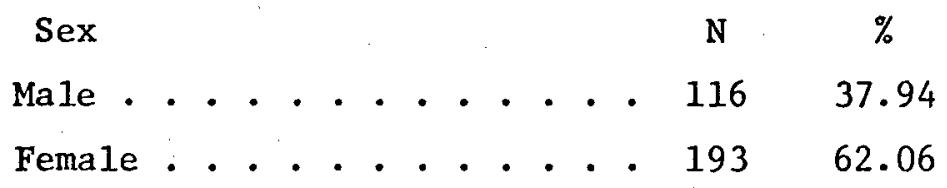

TABLE 3

AGE OF THE RESPONDENTS

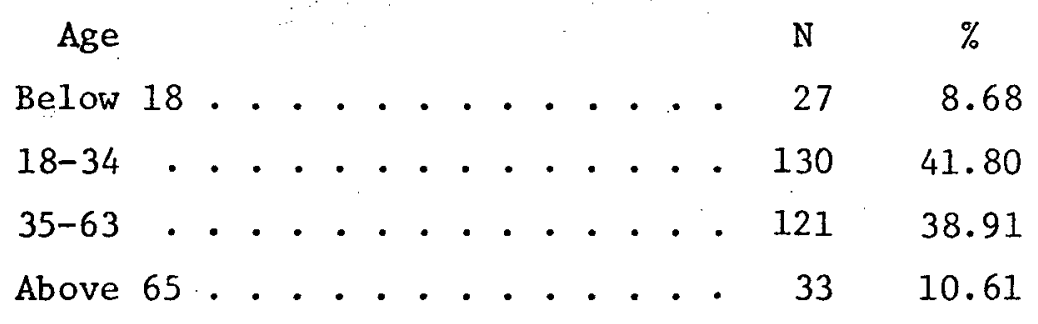

TABLE 4

LOCATION OF THE RESPONDENTS

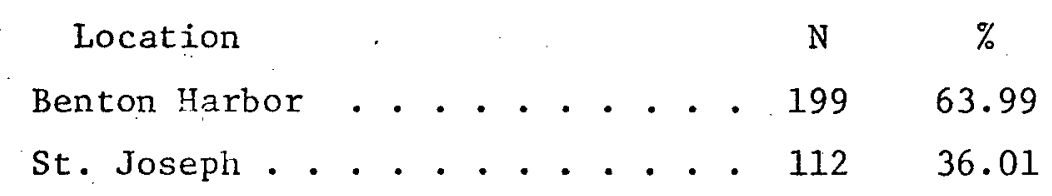

TABLE 5
RESPONDENTS' RELATIVE DEGREES OF INTEREST IN CHRISTIANITY

Degree of interest

in Christianity $\mathrm{N} \%$

Non-Christian . . . . . . $59 \quad 18.97$

1-Nominal Christian . . . . . $32 \quad 10.29$

2-Nominal Christian . . . . . . 6922.19

3-Nominal Christian . . . . . 151 48.55

\section{Overview of Format Findings}

As tables 6, 8, and 10 show, the most acceptable type of radio spot for most nominal and non-Christians includes (1) the use 
of music, (2) "someone telling a personal experience he has had," and (3), when Christianity is presented, "any Christian telling why he is one."

Tables 7, 9, and 11 also show that the most credible type of radio spot for the nominal and non-Christian has the same characteristics as the most acceptable type, with but one exception. There appears to be no clear-cut opinion regarding whether or not the use of music affects the credibility of a radio spot.

\section{TABLE 6}

THE INFLUENCE OF MUSIC ON ACCEPTABILITY OF RADIO SPOTS

$\begin{array}{cccc}\text { Influence of Music } & & \text { N } & \text { * } \\ \text { Prefer spots with music . . . . . . } & 195 & 62.70 \\ \text { Prefer spots without music . . . . } & 57 & 18.33 \\ \text { "It makes no difference" . . . . . } & 59 & 18.97\end{array}$

TABLE 7

THE INFLUENCE OF MUSIC ON CREDIBILITY OF RADIO SPOTS

$\begin{array}{ccccc}\text { Influence on Music } & & & \text { N } & \% \\ \text { Prefer spots with music . . . . . . } & \text {. } 110 & 35.37 \\ \text { Prefer spots without music } & \text {. . . . . } 107 & 34.41 \\ \text { "It makes no difference" } & \text {. . . . . . } & 94 & 30.23\end{array}$

TABLE 8

THE INFLUENCE OF FOUR FORMLAT TYPES

ON ACCEPTABILITY OF RADIO SPOTS

Format Type N N $\quad$ N

Announcer reading the script . . . . . . . . . 4213.50

Two people talking to each other . . . . . . . $61 \quad 19.61$

On-the-street interviews . . . . . . . . . . 60 19.29

Somone telling a personal experience he has had . . 125 : 40.19

"It makes no difference" . . . . . . . . . . 237.40 
TABLE 9

THE INFLUENCE OF FOUR FORMAT TYPES.

ON CREDIBILITY OF RADIO SPOTS

Format Type N

$\%$

Announcer reading the script . . . . . . . . . 4113.18

Two people talking to each other . . . . . . . . $49 \quad 15.76$

On-the-street interviews . . . . . . . . . . $62 \quad 19.94$

Someone telling a personal experience he has had . . 13342.77

"It makes no difference" . . . . . . . . . . 268

TABLE 10

THE INFLUENCE OF THREE TYPES OF COMMUNICATORS

ON ACCEPTABILITY OF RADIO SPOTS

Commicator N N

$\%$

A commentator discussing Christianity . . . . . . . 3611.58

A pastor explaining Christianity . . . . . . . 10634.08

Any Christian telling why he is one . . . . . . . 13543.41

"It makes no difference" . . . . . . . . . . $34 \quad 10.93$

TABLE 11

THE INFLUENCE OF THREE TYPES OF COMMUNICATORS

ON CREDIBILITY OF RADIO SPOTS

Communicator

$\mathrm{N} \quad \%$

A commentator discussing Christianity . . . . . . 227.07

A pastor explaining Christianity . . . . . . . . 11637.30

Any Christian telling why he is one . . . . . . 13543.41

"It makes no difference" . . . . . . . . . . 3812.22

Responses to Each Question According to Relative

Degree of Interest in Christianity

Question 4: The Influence of Music on Acceptability

of Radio Spots for Nominal and Non-Christians

As table 12 shows, all four categories of nominal and non-

Christians are "more inclined to listen to a one-minute radio presentation with music." More than three times as many persons in 
the non-Christian category preferred radio spots with music as those who did not prefer music in radio spots. The same is true of the 3-nominal Christians.

Most striking of all, however, is that thirteen times as many 1-nominal Christians prefer music in radio spots as those who do not; and six times as many 1-nominal Christians prefer music in radio spots as those for whom "it makes no difference."

TABLE 12

THE INFLUENCE OF MUSIC ON ACCEPTABILITY OF RADIO SPOTS FOR NOMINAL AND NON-CHRISTIANS

\begin{tabular}{|c|c|c|c|c|c|c|c|}
\hline \multirow[b]{2}{*}{ Type of Person } & \multicolumn{2}{|c|}{$\begin{array}{l}\text { With } \\
\text { Music }\end{array}$} & \multicolumn{2}{|c|}{$\begin{array}{l}\text { Without } \\
\text { Music }\end{array}$} & \multicolumn{2}{|c|}{$\begin{array}{l}\text { No Differ- } \\
\text { ence }\end{array}$} & \multirow{2}{*}{ Total } \\
\hline & $\mathrm{N}$ & $\%$ & $\mathrm{~N}$ & $\%$ & $\mathrm{~N}$ & $\%$ & \\
\hline 0 Non-Christian & 38 & 64.41 & 11 & 18.64 & 10 & 16.95 & 59 \\
\hline 1-Nominal Christian & 26 & 81.25 & 2 & 6.25 & 4 & 12.50 & 32 \\
\hline 2-Nominal Christian & 38 & 55.07 & 16 & 23.19 & 15 & 21.74 & 69 \\
\hline 3-Nominal Christian & 93 & 61.59 & 28 & 18.54 & 30 & 19.87 & 151 \\
\hline Totals & 195 & & 57 & & 59 & & 311 \\
\hline
\end{tabular}

Question 5: The Influence of Music on Credibility of Radio Spots on Nominal and Non-Christians

As table 13 shows, there appears to be no clear-cut agreement among nominal and non-Christians regarding the influence of music on credibility of radio spots. In all categories of nominal and nonChristians, approximately the same number of respondents believe that "a one-minute radio presentation sounds the most believable with music" as those who believe that "a one-minute radio presentation sounds the most believeable without music." This dichotomy of 
opinion may be further demonstrated in that almost as many persons answered "It makes no difference" as those who answered either "with music" or "without music."

TABLE 13

THE INFLUENCE OF IUSIC ON CREDIBILITY OF RADIO SPOTS FOR NOMINAL AND NON-CHRISTIANS

\begin{tabular}{|c|c|c|c|c|c|c|c|}
\hline \multirow[b]{2}{*}{ Type of Person } & \multicolumn{2}{|c|}{$\begin{array}{l}\text { With } \\
\text { Music }\end{array}$} & \multicolumn{2}{|c|}{$\begin{array}{l}\text { Without } \\
\text { Music }\end{array}$} & \multicolumn{2}{|c|}{$\begin{array}{l}\text { No Differ- } \\
\text { ence }\end{array}$} & \multirow{2}{*}{ Tota] } \\
\hline & $\mathrm{N}$ & $\%$ & $\mathrm{~N}$ & $\%$ & $\mathrm{~N}$ & $\%$ & \\
\hline 0 Non-Christian & 20 & 33.90 & 19 & 32.20 & 20 & 33.90 & 59 \\
\hline 1-Nominal Christian & 12 & 37.50 & 12 & 37.50 & 8 & 25.00 & 32 \\
\hline 2-Nominal Christian & 24 & 34.78 & 27 & 39.13 & 18 & 26.09 & 69 \\
\hline 3-Nominal Crhistian & 54 & 35.76 & 49 & 32.45 & 48 & 31.79 & 151 \\
\hline Totals & 110 & & 107 & & 94 & & 311 \\
\hline
\end{tabular}

Question 6: The Influence of Four Format Types on Acceptability of Radio Spots for Nomina1 and Non-Christians

As table 14 shows, three of the four categories of nominal and non-Christians preferred the format "Someone telling a personal experience he has had" above any of the other formats. In each of these three categories, approximately twice as many respondents preferred this format above any of the other formats.

The 2-nominal Christians, however, generally preferred the format "Two people talking to each other" above any of the other formats. 
TABLE 14

THE INFLUENCE OF FOUR FORMAT TYPES ON ACCEPTABILITY OF RADIO SPOTS FOR NOMINAL AND NON-CHRISTIANS

\begin{tabular}{|c|c|c|c|c|c|c|c|c|c|c|c|}
\hline Type of Person & \multicolumn{2}{|c|}{$\begin{array}{l}\text { Anncr. } \\
\text { Reading } \\
\text { Script }\end{array}$} & \multicolumn{2}{|c|}{ Dialogue } & \multicolumn{2}{|c|}{$\begin{array}{l}\text { On-the- } \\
\text { street } \\
\text { Interviews }\end{array}$} & \multicolumn{2}{|c|}{$\begin{array}{l}\text { Personal } \\
\text { Experience }\end{array}$} & \multicolumn{2}{|c|}{$\begin{array}{l}\text { No Differ- } \\
\text { ence }\end{array}$} & Total \\
\hline 0 ivon-Christian & 10 & 16.95 & 6 & 10.17 & 12 & 20.34 & 23 & 38.98 & 8 & 13.56 & 59 \\
\hline 1-Nominal Christian & 2 & 6.25 & 13 & 40.42 & 6 & 18.75 & 10 & 31.25 & 1 & 3.13 & 32 \\
\hline 3-Nominal Christian & 15 & 9.93 & 30 & 19.87 & 26 & 17.22 & 68 & 45.03 & 12 & 7.95 & 151 \\
\hline Totals & 42 & & 61 & & 60 & & 125 & & 23 & & 311 \\
\hline
\end{tabular}


Question 7: The Influence of Four Format Types on Credibility of Radio Spots for Nominal and Non-Christians

As table 15 shows, all four categories of nominal and nonChristians indicated that the format "Someone telling a personal experience he has had" was perceived to be more credible than any of the other formats. In all of these four categories, approximately twice as many respondents indicated that this format was more credible than any of the other formats.

Question 8: The Influence of Three Types of Communicators on Acceptability of Radio Spots for Nominal and Non-Christians

As table 16 indicates, three of the four categories of nominal and non-Christians preferred the type of communicator identified as "Any Christian telling why he is one" above any of the other communicator types. Only in the 1-nominal Christian and the 3-nominal Christian categories was this preference substantial. Among non-Christians, there were almost as many responses to the option "It makes no difference" as to "Any Christian telling why he is one." And among 2-nominal Christians, the "pastor" was slightly preferred over "any Christian."

\section{Question 9: The Influence of Three Types of Communicators on Credibility of Radio Spots for Nominal and Non-Christians}

As table 17 shows, three of the four categories of nominal and non-Christians indicated that the type of communicator identified as "Any Christian telling why he is one" was perceived to be more credible than any of the others.

It should be noted, however, that almost as many non- 
TABLE 15

THE INFLUENCE OF FOUR FORMAT TYPES OF CREDIBILITY OF RADIO SPOTS FOR NOMINAL AND NON-CHRISTIANS

\begin{tabular}{|c|c|c|c|c|c|c|c|c|c|c|c|}
\hline \multirow{2}{*}{ Type of Person } & \multicolumn{2}{|c|}{$\begin{array}{l}\text { Anncr. } \\
\text { Reading } \\
\text { Script }\end{array}$} & \multicolumn{2}{|c|}{ Dialogue } & \multicolumn{2}{|c|}{$\begin{array}{l}\text { On-the- } \\
\text { street } \\
\text { Interviews }\end{array}$} & \multicolumn{2}{|c|}{$\begin{array}{l}\text { Personal } \\
\text { Experience }\end{array}$} & \multicolumn{2}{|c|}{$\begin{array}{l}\text { No Differ- } \\
\text { ence }\end{array}$} & \multirow[b]{2}{*}{ Total } \\
\hline & N & $\%$ & $\mathrm{~N}$ & $\%$ & N & $\%$ & $\mathrm{~N}$ & $\%$ & $\mathrm{~N}$ & $\%$ & \\
\hline 0 Non-Christian & 9 & 15.25 & 9 & 15.25 & 12 & 20.34 & 20 & 33.90 & 9 & 15.25 & 59 \\
\hline 1-Nominal Christian & 3 & 9.38 & 9 & 28.12 & 7 & 21.87 & 12 & 37.50 & 1 & 3.13 & 32 \\
\hline 2-Nominal Christian & 13 & 18.84 & 9 & 13.04 & 12 & 17.39 & 30 & 43.48 & 5 & 7.25 & 69 \\
\hline 3-Nominal Christian & 16 & 10.60 & 22 & 14.57 & 31 & 20.53 & 71 & 47.02 & 11 & 7.28 & 151 \\
\hline Totals & 41 & & 49 & & 62 & & 133 & & 26 & & 311 \\
\hline
\end{tabular}


TABLE 16

THE INFLUENCE OF THREE TYPES OF COMMUNICATORS ON ACCEPTABILITY

OF RADIO SPOTS FOR NOMINAL AND NON-CHRISTIANS

\begin{tabular}{|c|c|c|c|c|c|c|c|c|c|}
\hline \multirow[b]{2}{*}{ Type of Person } & \multicolumn{2}{|c|}{$\begin{array}{l}\text { Commen- } \\
\text { tator }\end{array}$} & \multicolumn{2}{|c|}{ Pastor } & \multicolumn{2}{|c|}{$\begin{array}{l}\text { Any } \\
\text { Christian }\end{array}$} & \multicolumn{2}{|c|}{$\begin{array}{l}\text { No Differ- } \\
\text { ence }\end{array}$} & \multirow[b]{2}{*}{ Total } \\
\hline & $\mathrm{N}$ & $\%$ & $\mathrm{~N}$ & $\%$ & $\mathrm{~N}$ & $\%$ & $\mathrm{~N}$ & $\%$ & \\
\hline 0 Non-Christian & 8 & 13.56 & 16 & 27.12 & 18 & 30.51 & 17 & 28.81 & 59 \\
\hline 1-Nominal Christian & 4 & 12.50 & 6 & 18.75 & 18 & 56.25 & 4 & 12.50 & 32 \\
\hline 2-Nominal Christian & 11 & 15.94 & 29 & 42.03 & 25 & 36.23 & 4 & 5.80 & 69 \\
\hline 3-Nominal Christian & 13 & 8.61 & 55 & 36.42 & 74 & 49.01 & 9 & 5.96 & 151 \\
\hline Totals & 36 & & 106 & & 135 & & 34 & & 311 \\
\hline
\end{tabular}


TABLE 17

THE INFLUENCE OF THREE TYPES OF COMMUNICATORS ON CREDIBILITY OF RADIO SPOTS FOR NOMINAL AND NON-CHRISTIANS

\begin{tabular}{|c|c|c|c|c|c|c|c|c|c|}
\hline \multirow[b]{2}{*}{ Type of Person } & \multicolumn{2}{|c|}{$\begin{array}{l}\text { Commen- } \\
\text { tator }\end{array}$} & \multicolumn{2}{|c|}{ Pastor } & \multicolumn{2}{|c|}{$\begin{array}{l}\text { Any } \\
\text { Christian }\end{array}$} & \multicolumn{2}{|c|}{$\begin{array}{l}\text { No Differ- } \\
\text { ence }\end{array}$} & \multirow[b]{2}{*}{ Total } \\
\hline & $\mathrm{N}$ & $\%$ & $\mathrm{~N}$ & $\%$ & $\mathrm{~N}$ & $\%$ & $\mathrm{~N}$ & $\%$ & \\
\hline 0 Non-Christian & 3 & 5.08 & 19 & 32.20 & 20 & 33.90 & 17 & 28.81 & 59 \\
\hline 1-Nominal Christian & 3 & 9.38 & 12 & 37.50 & 15 & 46.87 & 2 & 6.25 & 32 \\
\hline 2-Nominal Christian & 6 & 8.70 & 33 & 47.83 & 24 & 34.78 & 6 & 8.70 & 69 \\
\hline 3-Nominal Christian & 10 & 6.62 & 52 & 34.44 & 76 & 50.33 & 13 & 8.61 & 151 \\
\hline Totals & 22 & & 116 & & 135 & & 38 & & 311 \\
\hline
\end{tabular}


Christians perceived the "pastor" to be the most credible communicator type of those listed. Further, only three of fifty-nine nonChristians indicated that the commentator was the most credible communicator type.

The 2-nominal Christians generally indicated that the pastor was the most credible communicator type.

\section{Responses to Each Question According to Age Categories}

Question 3: A Demographic Comparison of Age Categories to Relative Degree of Interest in Christianity

As table 18 shows, in all four age categories most respondents perceived themselves to be in the 3-nominal Christian category. In the below-18, 18-34, and 35-65 age categories, approximately twice as many respondents placed themselves in the 3 -nominal Christian category as in any other category. In the above-65 age category, almost four times as many respondents placed themselves in the 3-nominal Christian category as in any other category.

\section{Question 4: The Influence of Music on Acceptability of Radio Spots According \\ to Age Categories of Respondents}

As table 19 shows, in all four age categories most respondents were "more inclined to listen to a one-minute radio presentation with music" than without music.

In the below-18 age category, 25 of 27 respondents preferred radio spots with music. In the 18-34 age category, almost five times as many respondents preferred spots with music as those who answered otherwise. 
TABLE 18

A DEYOGRAPHIC COMPARISON OF AGE CATEGORIES TO RELATIVE DEGREE OF INTEREST IN CHRISTIANITY

\begin{tabular}{|c|c|c|c|c|c|c|c|c|c|}
\hline \multirow{2}{*}{$\begin{array}{l}\text { Age Cate- } \\
\text { gories of } \\
\text { Respondents }\end{array}$} & \multicolumn{2}{|c|}{$\begin{array}{l}\text { Non- } \\
\text { Christian }\end{array}$} & \multicolumn{2}{|c|}{$\begin{array}{l}\text { 1-Nominal } \\
\text { Christian }\end{array}$} & \multicolumn{2}{|c|}{$\begin{array}{l}\text { 2-Nominal } \\
\text { Christian }\end{array}$} & \multicolumn{2}{|c|}{$\begin{array}{l}\text { 3-Nominal } \\
\text { Christian }\end{array}$} & \multirow[b]{2}{*}{ Total } \\
\hline & $\mathrm{N}$ & $\%$ & $\mathrm{~N}$ & $\%$ & $\mathrm{~N}$. & $\%$ & $\mathrm{~N}$ & $\%$ & \\
\hline Below 18 & 5 & 18.52 & 6 & 22.22 & 6 & 22.22 & 10 & 37.04 & 27 \\
\hline $18-34$ & 25 & 19.23 & 18 & 13.85 & 32 & 24.61 & 55 & 42.31 & 130 \\
\hline $35-65$ & 25 & 20.66 & 5 & 4.13 & 25 & 20.66 & 66 & 54.54 & 121 \\
\hline Above 65 & 4 & 12.12 & 3 & 9.09 & 6 & 18.18 & 20 & 60.61 & 33 \\
\hline Totals & 59 & & 32 & & 69 & & 151 & & 311 \\
\hline
\end{tabular}

TABLE 19

THE INFLUENCE OF MUSIC ON ACCEPTABILITY OF RADIO SPOTS ACCORDING TO AGE CATEGORIES

OF RESPONDENTS

\begin{tabular}{|c|c|c|c|c|c|c|c|}
\hline \multirow{2}{*}{$\begin{array}{l}\text { Age Cate- } \\
\text { gories of } \\
\text { Respondents }\end{array}$} & \multicolumn{2}{|c|}{$\begin{array}{l}\text { With } \\
\text { Music }\end{array}$} & \multicolumn{2}{|c|}{$\begin{array}{l}\text { Without } \\
\text { Music }\end{array}$} & \multicolumn{2}{|c|}{$\begin{array}{l}\text { No Differ- } \\
\text { ence }\end{array}$} & \multirow[b]{2}{*}{ Total } \\
\hline & $N$ & $\%$ & $\mathrm{~N}$ & $\%$ & $\mathrm{~N}$ & $\%$ & \\
\hline Below 18 & 25 & 92.59 & 1 & 3.70 & 1 & 3.70 & 27 \\
\hline $18-34$ & 94 & 72.31 & 17 & 13.08 & 19 & 14.62 & 130 \\
\hline $35-65$ & 60 & 49.59 & 30 & 24.79 & 31 & 25.62 & 121 \\
\hline Above 65 & 16 & 48.48 & 9 & 27.27 & 8 & 24.24 & 33 \\
\hline Totals & 195 & & 57 & & 59 & & 311 \\
\hline
\end{tabular}


Apparently, the younger the age the greater the preference

for music in radio spots among nominal and non-Christians.

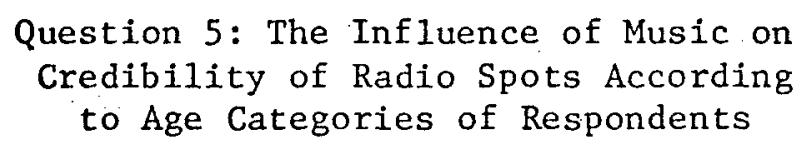

As table 20 shows, there is no general agreement among age categories regarding whether or not a "one-minute radio presentation sounds the most believable" with or without music. Nevertheless, the basic response trend is similar to that noted in question 4 . Apparently, radio spots with music are perceived to be more credible by those in younger age categories than by those in older age categories. Thus, the largest number of respondents in the below-18 and 18-34 age categories indicated that a radio spot with music is more credible for them than one without music. On the other hand, the largest number of respondents in the 35-65 age category indicated that "It makes no difference" whether or not music is used in a spot, in terms of credibility. And the largest number of respondents in the above- 65 age category indicated that, generally, radio spots are more credible to them without music.

\section{Question 6: The Influence of Four Format Types on Acceptability of Radio Spots According to Age Categories of Respondents}

As table 21 shows, the largest number of respondents in all four age categories were most inclined to listen to "Someone telling a personal experience he has had."

Apparently radio spots using this format are perceived to be more acceptable by those in older age categories than by those in younger age categories. Thus, approximately twice as many 
TABLE 20

THE INFLUENCE OF MUSIC ON CREDIBILITY OF RADIO SPOTS ACCORDING TO AGE CATEGORIES

OF RESPONDENTS

\begin{tabular}{|c|c|c|c|c|c|c|c|}
\hline \multirow{2}{*}{$\begin{array}{l}\text { Age Cate- } \\
\text { gories of } \\
\text { Respondents }\end{array}$} & \multicolumn{2}{|c|}{$\begin{array}{l}\text { With } \\
\text { Music }\end{array}$} & \multicolumn{2}{|c|}{$\begin{array}{l}\text { Without } \\
\text { Music }\end{array}$} & \multicolumn{2}{|c|}{$\begin{array}{l}\text { No Differ- } \\
\text { ence }\end{array}$} & \multirow[b]{2}{*}{ Total } \\
\hline & $\mathrm{N}$ & $\%$ & $\mathrm{~N}$ & $\%$ & $\mathrm{~N}$ & $\%$ & \\
\hline Below 18 & 12 & 44.44 & 9 & 33.33 & 6 & 22.22 & 27 \\
\hline $18-34$ & 53 & 40.77 & 44 & 33.85 & 33 & 25.38 & 130 \\
\hline $35-65$ & 35 & 28.93 & 41 & 33.88 & 45 & 37.19 & 121 \\
\hline Above 65 & 10 & 30.30 & 13 & 39.39 & 10 & 30.30 & 33 \\
\hline Totals & 110 & & 107 & & 94 & & 311 \\
\hline
\end{tabular}

respondents in the $34-65$ and above -65 age categories indicated more inclination to listen to this type of format than any of the other formats. The margin of difference was less among those in the 18-34 and below-18 age categories.

\section{Question 7: The Influence of Four Format. Types on Credibility of Radio Spots According to Age Categories of Respondents}

As table 22 shows, the largest number of respondents in all four age categories indicated that the format type which sounded the most believable to them was "Someone telling a personal experience he has had." However, an equal number of respondents in the below18 age category indicated that "On-the-street interviews" sounded equally credible to them.

In the 35-65 category, three times as many respondents indicated that the "personal experience" format type was the most 
TABLE 21

THE INFLUENCE OF FOUR FORMAT TYPES ON ACCEPTABILITY OF RADIO SPOTS ACCORDING TO AGE CATEGORIES OF RESPONDENTS

\begin{tabular}{|c|c|c|c|c|c|c|c|c|c|c|c|}
\hline \multirow[b]{2}{*}{ Age Category } & \multicolumn{2}{|c|}{$\begin{array}{l}\text { Anncr. } \\
\text { Reading }\end{array}$} & \multicolumn{2}{|c|}{ Dialogue } & \multicolumn{2}{|c|}{$\begin{array}{l}\text { On-the- } \\
\text { street } \\
\text { Interviews }\end{array}$} & \multicolumn{2}{|c|}{$\begin{array}{l}\text { Personal } \\
\text { Experience }\end{array}$} & \multicolumn{2}{|c|}{$\begin{array}{l}\text { No Differ- } \\
\text { ence }\end{array}$} & \multirow[b]{2}{*}{ Total } \\
\hline & $\mathrm{N}$ & $\%$ & $\mathrm{~N}$. & $\%$ & $\mathrm{~N}$ & $\%$ & $\mathrm{~N}$ & $\%$ & $\mathrm{~N}$ & $\%$ & \\
\hline Below 18 & 3 & 11.11 & 4 & 14.81 & 8 & 29.63 & 11 & 40.74 & 1 & 3.70 & 27 \\
\hline $18-34$ & 19 & 14.62 & 31 & 23.85 & 26 & 20.00 & 44 & 33.85 & 10 & 7.69 & 130 \\
\hline $35-65$ & 13 & 14.05 & 20 & 16.53 & 19 & 15.70 & 56 & 46.28 & 9 & 7.44 & 121 \\
\hline Above 65 & 3 & 9.09 & 6 & 18.18 & 7 & 21.21 & 14 & 42.42 & 3 & 9.09 & 33 \\
\hline Totals & 42 & & 61 & & 60 & & 125 & & 33 & & 311 \\
\hline
\end{tabular}


TABLE 22

THE INFLUENCE OF FOUR FORMAT TYPES ON CREDIBILITY OF RADIO SPOTS ACCORDING TO AGE CATEGORIES OF RESPONDENTS

\begin{tabular}{|c|c|c|c|c|c|c|c|c|c|c|c|}
\hline \multirow[b]{2}{*}{ Age Category } & \multicolumn{2}{|c|}{$\begin{array}{l}\text { Anncr. } \\
\text { Reading }\end{array}$} & \multicolumn{2}{|c|}{ Dialogue } & \multicolumn{2}{|c|}{$\begin{array}{l}\text { On-the- } \\
\text { street } \\
\text { Interviews }\end{array}$} & \multicolumn{2}{|c|}{$\begin{array}{l}\text { Personal } \\
\text { Experience }\end{array}$} & \multicolumn{2}{|c|}{$\begin{array}{l}\text { No Differ- } \\
\text { ence }\end{array}$} & \multirow[b]{2}{*}{ Total } \\
\hline & $\mathrm{N}$ & $\%$ & $\mathrm{~N}$ & $\%$ & $\mathrm{~N}$ & $\%$ & $\mathrm{~N}$ & $\%$ & $\mathrm{~N}$ & $\%$ & \\
\hline Below 18 & 2 & 7.41 & 5 & 18.52 & 9 & 33.33 & 9 & 33.33 & 2 & 7.41 & 27 \\
\hline $18-34$ & 14 & 10.77 & 25 & 19.23 & 30 & 23.08 & 52 & 40.00 & 9 & 6.92 & 130 \\
\hline $35-65$ & 19 & 15.70 & 13 & 10.74 & 19 & 15.70 & 60 & 49.59 & 10 & 8.26 & 121 \\
\hline Above 65 & 6 & 18.18 & 6 & 18.18 & 4 & 12.12 & 13 & 36.36 & 5 & .15 .15 & 33 \\
\hline Totals & 41 & & 49 & & 62 & & 133 & & 26 & & 311 \\
\hline
\end{tabular}


believable of the format types for them. Thus, this age category attributed greater credibility to this format type than any of the other age categories did.

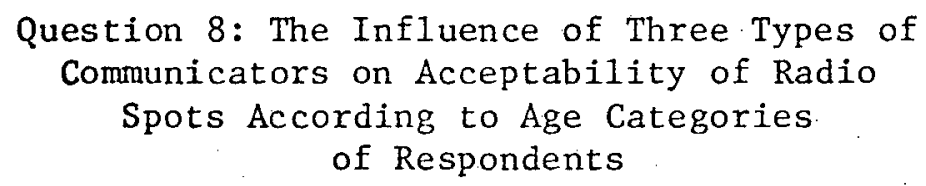

As table 23 shows, those in the below-18 and 18-34 age categories are most inclined to listen to "Any Christian telling why he is one," while those in the $35-65$ and above-65 age categories are most inclined to listen to. "A pastor explaining Christianity."

There is a significant, sequentially rank-ordered trend in these results. The younger the respondents, the greater their preference for "Any Christian telling why he is one." The older the respondents become, the greater their tendency to prefer "A pastor explaining Christianity."

Thus, three times as many respondents in the above-65 age category were most inclined to listen to "a pastor" as any other communicator type. In fact, over 60 percent preferred the pastor.

\section{Question 9: The Influence of Three Types of Communicators on Credibility of Radio Spots According to Age Categories of Respondents}

As table 24 shows, respondents in three out of the four age categories indicated that "Any Christian telling why he is one" was that type of communicator who sounded the most believable. The three age categories indicating thusly were the below-18, 13-34, and 35-65 age categories.

In striking contrast to this trend is the above- 65 age 
TABLE 23

THE INFLUENCE OF THREE TYPES OF COMMUNICATORS ON ACCEPTABILITY OF RADIO SPOTS ACCORDING TO AGE CATEGORIES OF RESPONDENTS

\begin{tabular}{|c|c|c|c|c|c|c|c|c|c|}
\hline Age Category & $\mathrm{N}$ & $\%$ & $\mathrm{~N}$ & $\%$ & $\mathrm{~N}$ & $\%$ & $\mathbf{N}$ & $\%$ & Total \\
\hline $18-34$ & 21 & 16.15 & 31 & 23.85 & 62 & 47.69 & 16 & 12.31 & 130 \\
\hline $35-65$ & 13 & 10.74 & 50 & 41.32 & 47 & 38.84 & 11 & 9.09 & 121 \\
\hline Totals & 36 & & 106 & & 135 & & 34 & & 311 \\
\hline
\end{tabular}


TABLE 24

THE INFLUENCE OF THREE TYPES OF COMMUNICATORS ON CREDIBILITY

OF RADIO SPOTS ACCORDING TO AGE CATEGORIES OF RESPONDENTS

\begin{tabular}{|c|c|c|c|c|c|c|c|c|c|}
\hline \multirow[b]{2}{*}{ Age Category } & \multicolumn{2}{|c|}{$\begin{array}{l}\text { Commen- } \\
\text { tator }\end{array}$} & \multicolumn{2}{|c|}{ Pastor } & \multicolumn{2}{|c|}{$\begin{array}{l}\text { Any } \\
\text { Christian }\end{array}$} & \multicolumn{2}{|c|}{$\begin{array}{l}\text { No Differ- } \\
\text { ence }\end{array}$} & \multirow[b]{2}{*}{ Total } \\
\hline & $\mathrm{N}$ & $\%$ & $\mathrm{~N}$ & $\%$ & $\mathrm{~N}$ & $\%$ & & $\%$ & \\
\hline Below 18 & 0 & 0 & 8 & 29.63 & 17 & 62.96 & 2 & 7.41 & 27 \\
\hline $18-34$ & 13 & 10.00 & 44 & 33.85 & 61 & 46.92 & 12 & 9.23 & 130 \\
\hline $35-65$ & 6 & 4.96 & 44 & 36.36 & 53 & 43.80 & 18 & 14.88 & 121 \\
\hline Above 65 & 3 & 9.09 & 20 & 60.61 & 4 & 12.12 & 6 & 18.17 & 33 \\
\hline Totals & 22 & & 116 & & 135 & & 38 & & 311 \\
\hline
\end{tabular}


category. Respondents in this age category indicated that the pastor was the most believable communicator type of those listed. More than three times as many respondents in this category chose the pastor above any other communicator type.

\section{Respondents to Each Question According to Race Categories}

Question 3: A Demographic Comparison of Race Categories to Relative Degree of Interest in Christianity

As table 25 shows, in all four race categories most respondents perceived themselves to be in the 3-nominal Christian category. A higher percentage of white respondents placed themselves in this category than black respondents. Yet, almost twice as many black respondents placed themselves in the non-Christian category as did white respondents.

\section{Question 4: The Influence of Music on Acceptability of Radio Spots According \\ to Race Categories of Respondents}

As table 26 shows, in all four race categories most respondents were "more inclined to 1 isten to a one-minute radio presentation with music" than without music.

Three times as many white respondents preferred radio spots with music as those who indicated otherwise. Four times as many black respondents preferred radio spots with music as those who indicated otherwise. 
TABLE 25

A DEMOGRAPHIC COMPARISON OF RACE CATEGORIES TO RELATIVE DEGREE OF . INTEREST IN CHRISTIANITY

\begin{tabular}{|c|c|c|c|c|c|c|c|c|c|}
\hline \multirow{2}{*}{$\begin{array}{l}\text { Race Cate- } \\
\text { gories of } \\
\text { Respondents }\end{array}$} & \multicolumn{2}{|c|}{$\begin{array}{l}\text { Non- } \\
\text { Christian }\end{array}$} & \multicolumn{2}{|c|}{$\begin{array}{l}\text { 1-Nominal } \\
\text { Christian }\end{array}$} & \multicolumn{2}{|c|}{$\begin{array}{l}\text { 2-Nominal } \\
\text { Christian }\end{array}$} & \multicolumn{2}{|c|}{$\begin{array}{l}\text { 3-Nominal } \\
\text { Christian }\end{array}$} & \multirow[b]{2}{*}{ Total } \\
\hline & $\mathrm{N}$ & $\%$ & $\mathrm{~N}$ & $\%$ & $\mathrm{~N}$ & $\%$ & $\mathrm{~N}$ & $\%$ & \\
\hline White & 44 & 17.05 & 28 & 10.85 & 60 & 23.25 & 126 & 48.84 & 258 \\
\hline Black & 15 & 30.61 & 4 & 8.16 & 9 & 18.37 & 21 & 42.85 & 49 \\
\hline Spanish & 0 & 0 & 0 & 0 & 0 & 0 & 1 & 100.00 & 1 \\
\hline Other & 0 & 0 & 0 & 0 & 0 & 0 & 1 & 100.00 & 2 \\
\hline Totals & 59 & & 32 & & 69 & & 150 & & 310 \\
\hline
\end{tabular}

TABLE 26

THE INFLUENCE OF MUSIC ON ACCEPTABILITY OF RADIO SPOTS ACCORDING TO RACE CATEGORIES

OF RESPONDENTS

\begin{tabular}{|c|c|c|c|c|c|c|c|}
\hline \multirow{2}{*}{$\begin{array}{l}\text { Race Cate- } \\
\text { gories of } \\
\text { Respondents }\end{array}$} & \multicolumn{2}{|c|}{$\begin{array}{l}\text { With } \\
\text { Music }\end{array}$} & \multicolumn{2}{|c|}{$\begin{array}{l}\text { Without } \\
\text { Music }\end{array}$} & \multicolumn{2}{|c|}{$\begin{array}{l}\text { No Differ- } \\
\text { ence }\end{array}$} & \multirow[b]{2}{*}{ Total } \\
\hline & $\mathrm{N}$ & $\%$ & $\mathrm{~N}$ & $\%$ & $\mathrm{~N}$ & $\%$ & \\
\hline White & 158 & 61.24 & 49 & 18.99 & 51 & 19.77 & 258 \\
\hline Black & 34 & 69.39 & 8 & 16.33 & 7 & 14.29 & 49 \\
\hline Spanish & & 100.00 & 0 & 0 & 0 & 0 & 1 \\
\hline Other & & 100.00 & 0 & 0 & 0 & 0 & 2 \\
\hline Totals & 195 & & 57 & & 58 & & 310 \\
\hline
\end{tabular}


Question 5: The Influence of Music on Credibility of Radio Spots According to Race Categories of Respondents

As table 27 shows, the largest number of white respondents indicated that radio spots without music are the "most believable" sounding, whereas the largest number of black respondents indicated that radio spots with music were the most believable sounding for them.

There is, however, no substantial, clear-cut opinion regarding the influence of music on credibility of radio spots according to white respondents.

TABLE 27

THE INFLUENCE OF MUSIC ON CREDIBILITY OF RADIO SPOTS ACCORDING TO RACE CATEGORIES

OF RESPONDENTS

\begin{tabular}{|c|c|c|c|c|c|c|c|}
\hline \multirow{2}{*}{$\begin{array}{l}\text { Race Cate- } \\
\text { gories of } \\
\text { Respondents }\end{array}$} & \multicolumn{2}{|c|}{$\begin{array}{l}\text { With } \\
\text { Music }\end{array}$} & \multicolumn{2}{|c|}{$\begin{array}{l}\text { Without } \\
\text { Music }\end{array}$} & \multicolumn{2}{|c|}{$\begin{array}{l}\text { No Differ- } \\
\text { ence }\end{array}$} & \multirow[b]{2}{*}{ Total } \\
\hline & $\mathrm{N}$ & $\%$ & $\mathrm{~N}$ & $\%$ & $\mathrm{~N}$ & $\%$ & \\
\hline White & 83 & 32.17 & 92 & 35.66 & 83 & 32.17 & 258 \\
\hline Black & 24 & 48.98 & 15 & 30.61 & 10 & 20.41 & 49 \\
\hline Spanish & & 100.00 & 0 & 0 & 0 & 0 & 1 \\
\hline Other & & 100.00 & 0 & 0 & 0 & 0 & 2 \\
\hline Totals & 110 & & 107 & & 93 & & 310 \\
\hline
\end{tabular}

Question 6: The Influence of Four Format Types on Acceptability of Radio Spots According to Race Categories of Respondents

As table 28 shows, there is a substantial preference among both white and black respondents for the format type "Someone telling 
TABLE 28

THE INFLUENCE OF FOUR FORMAT TYPES ON ACCEPTABILITY OF RADIO SPOTS ACCORDING TO RACE CATEGORIES OF RESPONDENTS

\begin{tabular}{|c|c|c|c|c|c|c|c|c|c|c|c|}
\hline \multirow{2}{*}{$\begin{array}{l}\text { Race Categories } \\
\text { of Respondents }\end{array}$} & \multicolumn{2}{|c|}{$\begin{array}{l}\text { Anncr. } \\
\text { Reading }\end{array}$} & \multicolumn{2}{|c|}{ Dialogue } & \multicolumn{2}{|c|}{$\begin{array}{l}\text { On-the- } \\
\text { street } \\
\text { Interviews }\end{array}$} & \multicolumn{2}{|c|}{$\begin{array}{l}\text { Personal } \\
\text { Experience }\end{array}$} & \multicolumn{2}{|c|}{$\begin{array}{l}\text { No Differ- } \\
\text { ence }\end{array}$} & \multirow[b]{2}{*}{ Total } \\
\hline & $\mathrm{N}$ & $\%$ & $\mathrm{~N}$ & $\%$ & $\mathrm{~N}$ & $\%$ & $\mathrm{~N}$ & $\%$ & & $\%$ & \\
\hline White & 39 & 15.12 & 49 & 18.99 & 48 & 18.60 & 104 & 40.31 & 18 & 6.98 & 258 \\
\hline Black & 3 & 6.12 & 12 & 24.49 & 11 & 22.45 & 18 & 36.73 & 5 & 10.20 & 49 \\
\hline Spanish & 0 & 0 & 0 & 0 & & 100.00 & 0 & 0 & 0 & 0 & 1 \\
\hline Other & 0 & 0 & 0 & 0 & 0 & 0 & 2 & 100.00 & 0 & 0 & 2 \\
\hline Totals & 42 & & 61 & & 60 & & 124 & & 23 & & 310 \\
\hline
\end{tabular}


a personal experience he has had." Twice as many white respondents chose this format type above any of the other format types.

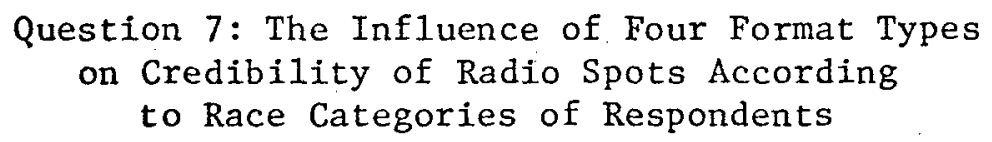

As table 29 shows, over twice as many white and black respondents indicated that the most believable sounding format type for them was "Someone telling a personal experience he has had." Slightly more respondents in both of these race categories indicated that this format type was more credible than those in the same race categories who indicated that this format type was acceptable (based on a comparison of tables 28 and 29 ).

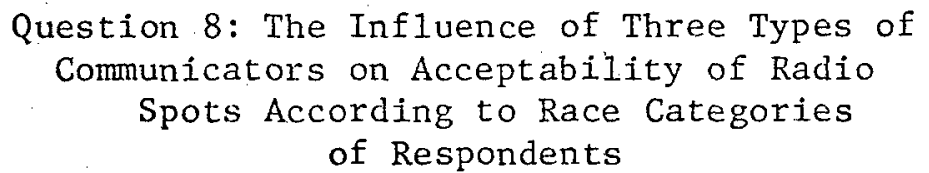

As table 30 shows, the largest number of white respondents indicated that the communicator type they were "most inclined to 1isten to" was "Any Christian telling why he is one."

Among black respondents, however, there was almost equal

preference for the "pastor" and "any Christian" communicator types.

\section{Question 9: The Influence of Three Types of Communicators on Credibility of Radio Spots According to Race Categories of Respondents}

As table 31 shows, the largest number of white respondents indicated that the format type which was "most believable" for them was "Any Christian telling why he is one." On the other hand, the largest number of black respondents indicated that the format type 
TABLE 29

THE INFLUENCE OF FOUR FORMAT TYPES ON CREDIBILITY OF RADIO SPOTS ACCORDING TO RACE CATEGORIES OF RESPONDENTS

\begin{tabular}{|c|c|c|c|c|c|c|c|c|c|c|c|}
\hline $\begin{array}{l}\text { Race Cate- } \\
\text { gories of } \\
\text { Respondents }\end{array}$ & N & $\%$ & $\mathrm{~N}$ & $\%$ & $\mathrm{~N}$ & $\%$ & N & $\%$ & $\mathrm{~N}$ & $\%$ & Total \\
\hline White & 34 & 13.18 & 42 & 16.28 & 49 & 18.99 & 110 & 42.64 & 23 & 8.91 & 258 \\
\hline Black & 7 & 14.29 & 7 & 14.29 & 10 & 20.41 & 22 & 44.90 & 3 & 6.12 & 49 \\
\hline Spanish & 0 & 0 & 0 & 0 & 1 & .100 .00 & 0 & 0 & 0 & 0 & 1 \\
\hline Other & 0 & 0 & 0 & 0 & 1 & 50.00 & 1 & 50.00 & 0 & 0 & 2 \\
\hline Totals & 41 & & 49 & & 61 & & 133 & & 26 & & 310 \\
\hline
\end{tabular}


TABLE 30

THE INFLUENCE OF THREE TYPES OF COMMUNICATORS ON ACCEPTABILITY

OF RADIO SPOTS ACCORDING TO RACE CATEGORIES OF RESPONDENTS

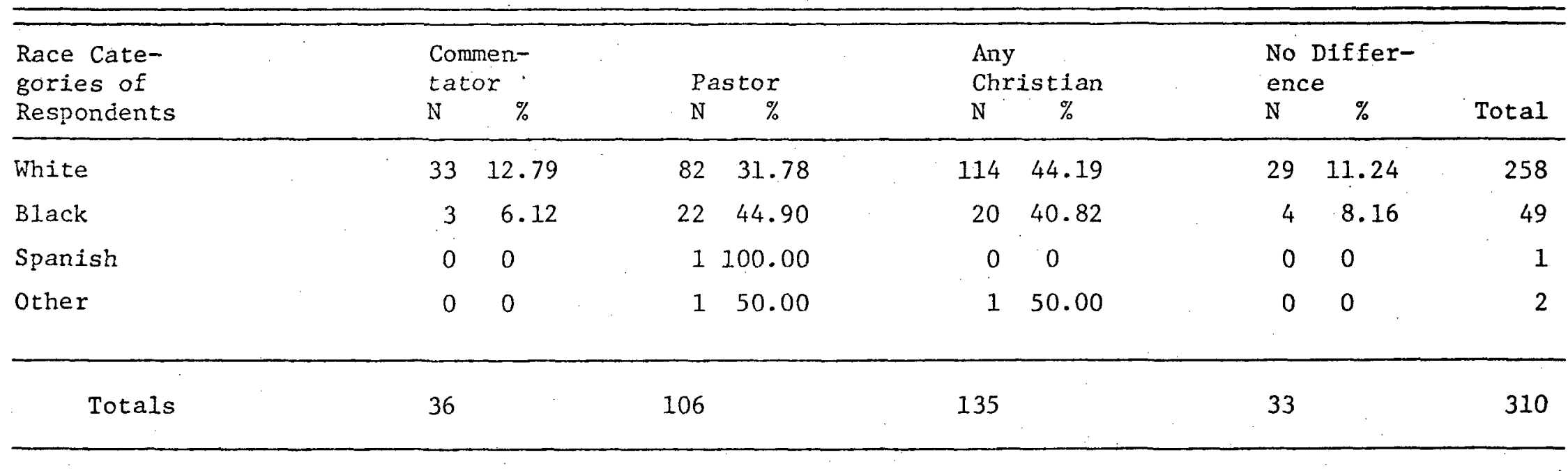


TABLE 31

THE INFLUENCE OF THREE TYPES OF COMMUNICATORS ON CREDIBILITY

OF RADIO SPOTS ACCORDING TO RACE CATEGORIES OF RESPONDENTS

\begin{tabular}{|c|c|c|c|c|c|c|c|c|}
\hline \multirow{2}{*}{$\begin{array}{l}\text { Race Cate- } \\
\text { gories of } \\
\text { Respondents }\end{array}$} & \multicolumn{2}{|c|}{$\begin{array}{l}\text { Commen- } \\
\text { tator }\end{array}$} & Pastor & \multicolumn{2}{|c|}{$\begin{array}{l}\text { Any } \\
\text { Christian }\end{array}$} & \multicolumn{2}{|c|}{$\begin{array}{l}\text { No Differ- } \\
\text { ence }\end{array}$} & \multirow[b]{2}{*}{ Total } \\
\hline & $\mathrm{N}$ & $\%$ & $\mathrm{~N} \quad \%$ & $\mathrm{~N}$ & $\%$ & $\mathrm{~N}$ & $\%$ & \\
\hline White & 18 & 6.98 & $90 \quad 34.88$ & 114 & 44.19 & 36 & 13.95 & 258 \\
\hline Black & 4 & 8.16 & $24 \quad 48.98$ & 19 & 38.78 & 2 & 4.08 & 49 \\
\hline Spanish & 0 & 0 & 1100.00 & 0 & 0 & 0 & 0 & 1 \\
\hline Other & 0 & 0 & 150.00 & 1 & 50.00 & 0 & 0 & 2 \\
\hline Totals & 22 & & 116 & 134 & & 38 & & 310 \\
\hline
\end{tabular}


which was "most believable" for them was "A pastor explaining Christianity." In both cases; however, there is only a 10 percent margin of preference between the first and second choices of the race categories.

Responses to Each Question According to Sex of Respondents

Question 3: A Demographic Comparison of Sex of Respondents to Their. Relative Degree of Interest in Christianity

As table 32 shows, the largest number of both male and female respondents was in the 3-nominal Christian category. However, there were substantially more female respondents who placed themselves into this category than male respondents.

TABLE 32

A DEMOGRAPHIC COMPARISON OF SEX OF RESPONDENTS TO THEIR RELATIVE DEGREE OF INTEREST IN CHRISTIANITY

\begin{tabular}{|c|c|c|c|c|c|c|c|c|c|}
\hline \multirow{2}{*}{$\begin{array}{l}\text { Sex of } \\
\text { Respon- } \\
\text { dents }\end{array}$} & \multicolumn{2}{|c|}{$\begin{array}{l}\text { Non- } \\
\text { Christian }\end{array}$} & \multicolumn{2}{|c|}{$\begin{array}{l}\text { 1-Nominal } \\
\text { Christian }\end{array}$} & \multicolumn{2}{|c|}{$\begin{array}{l}\text { 2-Nominal } \\
\text { Christian }\end{array}$} & \multicolumn{2}{|c|}{$\begin{array}{l}\text { 3-Nominal } \\
\text { Christian }\end{array}$} & \multirow[b]{2}{*}{ Tota1 } \\
\hline & $\mathrm{N}$ & $\%$ & $\mathrm{~N}$ & $\%$ & $\mathrm{~N}$ & $\%$ & $\mathrm{~N}$ & $\%$ & \\
\hline Male & 29 & 25.00 & 14 & 12.07 & 28 & 24.14 & 45 & 38.79 & 116 \\
\hline Female & 30 & 15.54 & 18 & 9.37 & 40 & 20.73 & 105 & 54.40 & 193 \\
\hline Totals & 59 & & 32 & & 68 & & 150 & & 309 \\
\hline
\end{tabular}

Question 4: The Influence of Music on Acceptability of Radio Spots According to the Sex of the Respondents

As table 33 shows, the majority of both male and female respondents were "more inclined to listen to a one-minute radio 
presentation with music" than without music.

The female respondents had the greatest preference for the use of music in radio spots.

TABLE 33

THE INFLUENCE OF MUSIC ON ACCEPTABILITY OF RADIO SPOTS ACCORDING TO THE SEX OF THE RESPONDENTS

\begin{tabular}{|c|c|c|c|c|c|c|c|}
\hline \multirow{2}{*}{$\begin{array}{l}\text { Sex of } \\
\text { Respondents }\end{array}$} & \multicolumn{2}{|c|}{$\begin{array}{l}\text { With } \\
\text { Music }\end{array}$} & \multicolumn{2}{|c|}{$\begin{array}{l}\text { Without } \\
\text { Music }\end{array}$} & \multicolumn{2}{|c|}{$\begin{array}{l}\text { No Differ- } \\
\text { ence }\end{array}$} & \multirow[b]{2}{*}{ Total } \\
\hline & $\mathrm{N}$ & $\%$ & $\mathrm{~N}$ & $\%$ & $\mathrm{~N}$ & $\%$ & \\
\hline Male & 67 & 57.76 & 25 & 21.55 & 24 & 20.69 & 116 \\
\hline Female & 127 & 65.80 & 31 & 16.06 & 35 & 18.13 & 193 \\
\hline Totals & 194 & & 56 & & 59 & & 309 \\
\hline
\end{tabular}

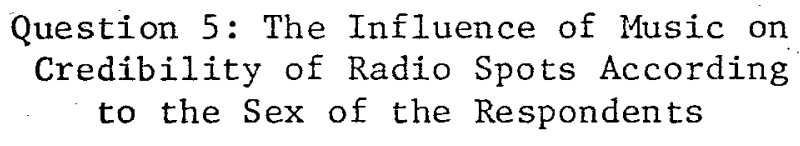

As table 34 shows, the largest number of male respondents indicated that radio spots without music sound the "most believable" to them. On the other hand, the largest number of female respondents indicated that radio spots with music sound the "most believable to them."

For male respondents, this is a radical shift in response from what they indicated in question 4. Apparently, then, male respondents prefer to listen to radio spots with music, but, at the same time, think radio spots without music are the most believable. 
TABLE 34

THE INFLUENCE OF MUSIC ON CREDIBILITY OF RADIO SPOTS ACCORDING TO THE SEX OF THE RESPONDENTS

\begin{tabular}{|c|c|c|c|c|c|c|c|}
\hline \multirow{2}{*}{$\begin{array}{l}\text { Sex of } \\
\text { Respondents }\end{array}$} & \multicolumn{2}{|c|}{$\begin{array}{l}\text { With } \\
\text { Music }\end{array}$} & \multicolumn{2}{|c|}{$\begin{array}{l}\text { Without } \\
\text { Music }\end{array}$} & \multicolumn{2}{|c|}{$\begin{array}{l}\text { No Differ- } \\
\text { ence }\end{array}$} & \multirow[b]{2}{*}{ Tota1 } \\
\hline & $\mathrm{N}$ & $\%$ & $\mathrm{~N}$ & $\%$ & $\mathrm{~N}$ & $\%$ & \\
\hline Male & 32 & 27.59 & 49 & 42.24 & 35 & 30.17 & 116 \\
\hline Female & 78 & 40.41 & 56 & 29.02 & 59 & 30.57 & 193 \\
\hline Totals & 110 & & 105 & & 94 & & 309 \\
\hline
\end{tabular}

Question 6: The Influence of Four Format Types on Acceptability of Radio Spots According

to the Sex of the Respondents

As table 35 shows, twice as many male and female respondents preferred the format "Someone telling a personal experience he has had" above any of the other format types.

Also, the response pattern indicates that this format has a slightly stronger appeal for female respondents than for male respondents.

Question 7: The Influence of Four Format Types on Credibility of Radio Spots According to the Sex of the Respondents

As table 36 shows, both male and female respondents indicated that the "most believable" format for them was "Someone telling a personal experience he has had." This format was selected two times more than any of the other formats listed. 


\section{TABLE 35}

THE INFLUENCE OF FOUR FORMAT TYPES ON ACCEPTABILITY OF RADIO SPOTS ACCORDING TO THE SEX OF THE RESPONDENTS

\begin{tabular}{|c|c|c|c|c|c|c|c|c|c|c|c|}
\hline \multirow{2}{*}{$\begin{array}{l}\text { Sex of } \\
\text { Respondents }\end{array}$} & \multicolumn{2}{|c|}{$\begin{array}{l}\text { Anncr. } \\
\text { Reading }\end{array}$} & \multicolumn{2}{|c|}{ Dialogue } & \multicolumn{2}{|c|}{$\begin{array}{l}\text { On-the- } \\
\text { street } \\
\text { Interviews }\end{array}$} & \multicolumn{2}{|c|}{$\begin{array}{l}\text { Personal } \\
\text { Experience }\end{array}$} & \multicolumn{2}{|c|}{$\begin{array}{l}\text { No Differ- } \\
\text { ence. }\end{array}$} & \multirow[b]{2}{*}{ Total } \\
\hline & $\mathrm{N}$ & $\%$ & $\mathrm{~N}$ & $\%$ & $\mathrm{~N}$ & $\%$ & $\mathrm{~N}$ & $\%$ & $\mathrm{~N}$ & $\%$ & \\
\hline Male & 19 & 16.38 & 28 & 24.14 & 22 & 18.97 & 40 & 34.48 & 7 & 6.03 & 116 \\
\hline Female & 23 & 11.92 & 33 & 17.20 & 37 & 19.17 & 84 & 43.52 & 16 & 8.29 & 193 \\
\hline Totals & 42 & & 61 & & 59 & & 124 & & 23 & & 309 \\
\hline
\end{tabular}


TABLE 36

THE INFLUENCE OF FOUR FORMAT TYPES OF CREDIBILITY OF RADIO SPOTS ACCORDING TO THE SEX OF THE RESPONDENTS

\begin{tabular}{|c|c|c|c|c|c|c|c|c|c|c|c|}
\hline \multirow{2}{*}{$\begin{array}{l}\text { Sex of } \\
\text { Respondents }\end{array}$} & \multicolumn{2}{|c|}{$\begin{array}{l}\text { Anncr. } \\
\text { Reading }\end{array}$} & \multicolumn{2}{|c|}{ Dialogue } & \multicolumn{2}{|c|}{$\begin{array}{l}\text { On-the } \\
\text { street } \\
\text { Interviews }\end{array}$} & \multicolumn{2}{|c|}{$\begin{array}{l}\text { Personal } \\
\text { Experience }\end{array}$} & \multicolumn{2}{|c|}{$\begin{array}{l}\text { No Differ- } \\
\text { ence }\end{array}$} & \multirow[b]{2}{*}{ Total } \\
\hline & $\mathrm{N}$ & $\%$ & $\mathrm{~N}$ & $\%$ & $\mathrm{~N}$ & $\%$ & $\mathrm{~N}$ & $\%$ & & $\%$ & \\
\hline Male & 21 & 18.10 & 20 & 17.24 & 23 & 19.83 & 41 & 35.34 & 11 & 9.48 & 116 \\
\hline Female & 20 & 10.36 & 29 & 15.03 & 38 & 19.69 & 91 & 47.15 & 15 & 7.77 & 193 \\
\hline Totals & 41 & & 49 & & 61 & & 132 & & 26 & & 309 \\
\hline
\end{tabular}


Question 3: The Influence of Three Types of

Communicators on Acceptability of Radio

Spots According to the Sex

of the Respondents

As table 37 shows, in both male and female categories the largest number of respondents indicated that they were "most

inclined to listen to any Christian telling why he is one."

Also, a substantially larger percentage of male respondents

preferred the "commentator" communicator than did female respondents.

\section{Question 9: The Influence of Three Types of \\ Communicators on Credibility of Radio \\ Spots According to the Sex \\ of the Respondents}

As table 38 shows, in both male and female categories the largest number of respondents indicated that the "most believable" communicator type was "Any Christian telling why he is one." It should be noted, however, that almost as many males indicated that the "most believable" communicator type was "A pastor explaining Christianity."

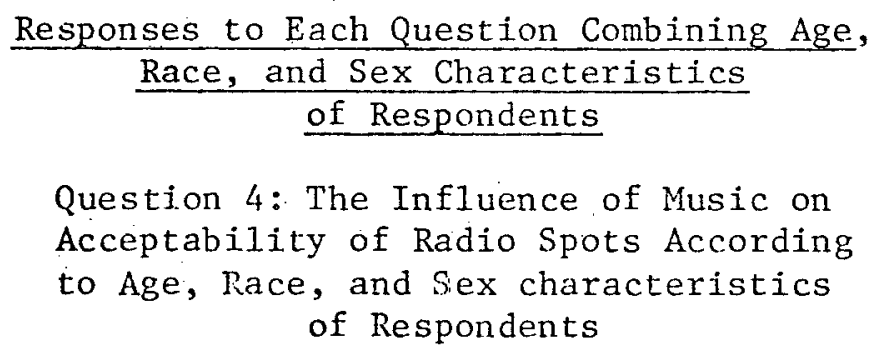

As table 39 shows, a preference trend emerges in the white male category. The younger the white male, the more he prefers the use of music in radio spots. As the white male becomes older, his preference for the use of music in radio spots diminishes proportionately. Whereas 91 percent of the below-18, white, male 
TABLE 37

THE INFLUENCE OF THREE TYPES OF COMMUNICATORS ON ACCEPTABILITY OF RADIO SPOTS ACCORDING TO THE SEX OF THE RESPONDENTS

\begin{tabular}{|c|c|c|c|c|c|c|c|c|c|}
\hline \multirow{2}{*}{$\begin{array}{l}\text { Sex of } \\
\text { Respondents }\end{array}$} & \multicolumn{2}{|c|}{$\begin{array}{l}\text { Commen- } \\
\text { tator }\end{array}$} & \multicolumn{2}{|c|}{ Pastor } & \multicolumn{2}{|c|}{$\begin{array}{l}\text { Any } \\
\text { Christian }\end{array}$} & \multicolumn{2}{|c|}{$\begin{array}{l}\text { No Differ- } \\
\text { ence }\end{array}$} & \multirow[b]{2}{*}{ Total } \\
\hline & $\mathrm{N}$ & & $\mathrm{N}$ & $\%$ & $\mathrm{~N}$ & $\%$ & & $\%$ & \\
\hline Male & 21 & 18.10 & 35 & 30.17 & 44 & 37.93 & 16 & 13.79 & 116 \\
\hline Female & 15 & 7.77 & 70 & 36.27 & 90 & 46.63 & 18 & 9.33 & 193 \\
\hline Totals & 36 & & 105 & & 134 & & 34 & & 309 \\
\hline
\end{tabular}


TABLE 38

THE INFLUENCE OF THREE TYPES OF COMMUNICATORS ON CREDIBILITY OF RADIO SPOTS ACCORDING TO THE SEX OF THE RESPONDENTS

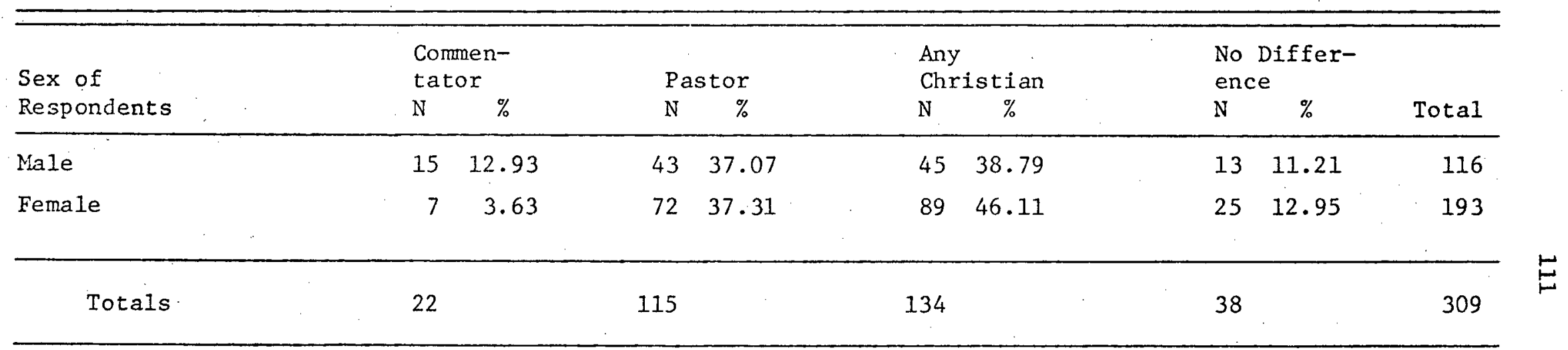


TABLE 39

THE INFLUENCE OF MUSIC ON ACCEPTABILITY OF RADIO

SPOTS ACCORDING TO AGE, RACE, AND SEX

CHARACTERISTICS OF RESPONDENTS

\begin{tabular}{|c|c|c|c|c|c|c|}
\hline \multirow{2}{*}{$\begin{array}{l}\text { Characteristics of } \\
\text { Respondents }\end{array}$} & \multicolumn{2}{|c|}{$\begin{array}{l}\text { With } \\
\text { Music }\end{array}$} & \multicolumn{2}{|c|}{$\begin{array}{l}\text { Without } \\
\text { Music }\end{array}$} & \multicolumn{2}{|c|}{$\begin{array}{l}\text { No Differ- } \\
\text { erence }\end{array}$} \\
\hline & $\mathrm{N}$ & $\%$ & $\mathrm{~N}$ & $\%$ & $\mathrm{~N}$ & $\%$ \\
\hline Below 18, white, male & 10 & 91 & 1 & 9 & 0 & 0 \\
\hline Below 18, white, female & 12 & 92 & 0 & 0 & 1 & 8 \\
\hline Below 18, black, male & 0 & 0 & 0 & 0 & 0 & 0 \\
\hline Below 18, black, female & 3 & 100 & 0 & 0 & 0 & 0 \\
\hline Below 18, Spanish, male & 0 & 0 & 0 & 0 & 0 & 0 \\
\hline Below 18, Spanish, female & 0 & 0 & 0 & 0 & 0 & 0 \\
\hline Below 18, other, male & 0 & 0 & 0 & 0 & 0 & 0 \\
\hline Below 18, other, female & 0 & 0 & 0 & 0 & 0 & 0 \\
\hline 18-34, white, male & 26 & 72 & 4 & 11 & 6 & 17 \\
\hline 18-34, white, female & 47 & 70 & 9 & 14 & 11 & 16 \\
\hline 18-34, black, male & 8 & 80 & 1 & 10 & 1 & 10 \\
\hline 18-34, black, female & 12 & 80 & 2 & 13 & 1 & 7 \\
\hline 18-34, Spanish, male & 0 & 0 & 0 & 0 & 0 & 0 \\
\hline 18-34, Spanish, female & 0 & 0 & 0 & 0 & 0 & 0 \\
\hline 18-34, other, male & 0 & 0 & 0 & 0 & 0 & 0 \\
\hline 18-34, other, female & 1 & 100 & 0 & 0 & 0 & 0 \\
\hline 35-65, white, male & 16 & 42 & 11 & 29 & 11 & 29 \\
\hline 35-65, white, female & 31 & 49 & 15 & 24 & 17 & 27 \\
\hline 35-65, black, male & 3 & 43 & 3 & 43 & 1 & 14 \\
\hline 35-65, black, female & 7 & 78 & 1 & 11 & 1 & 11 \\
\hline 35-65, Spanish, male & 0 & 0 & 0 & 0 & 0 & 0 \\
\hline 35-65, Spanish, female & 1 & 100 & 0 & 0 & 0 & 0 \\
\hline $35-65$, other, male & 0 & 0 & 0 & 0 & 0 & 0 \\
\hline $35-65$, other, female & 1 & 100 & 0 & 0 & 0 & 0 \\
\hline Above 65 , white, male & 4 & 40 & 4 & 40 & 2 & 20 \\
\hline Above 65 , white, female & 11 & 61 & 4 & 22 & 3 & 17 \\
\hline Above 65 , black, male & 0 & 0 & 1 & 25 & 3 & 75 \\
\hline Above 65 , black, female & 1 & 100 & 0 & 0 & 0 & 0 \\
\hline Above 65, Spanish, male & 0 & 0 & 0 & 0 & 0 & 0 \\
\hline Above 65 , Spanish, female & 0 & 0 & 0 & 0 & 0 & 0 \\
\hline Above 65 , other, male & 0 & 0 & 0 & 0 & 0 & 0 \\
\hline Above 54 , other, female & 0 & 0 & 0 & 0 & 0 & 0 \\
\hline
\end{tabular}


respondents preferred the use of music in radio spots, only 40 percent of the above-65, white; male respondents preferred the use of music in radio spots.

This trend appears to be similar for black male respondents, although no black males in the below-18 age category were included in the frame. Whereas 80 percent of the 18-34 year old black male respondents preferred the use of music in radio spots, only 43 percent of the 35-65 year old black males preferred the use of music in radio spots, and none in the above- 65 age category preferred it (where 75 percent of the black male respondents answered "It makes no difference").

White female respondents also show a similar trend through the 35-65 age category. But their preference for the use of music in radio spots increases substantially in the above-65 age category.

The black female respondent trend is identical to the white female trend in this respect.

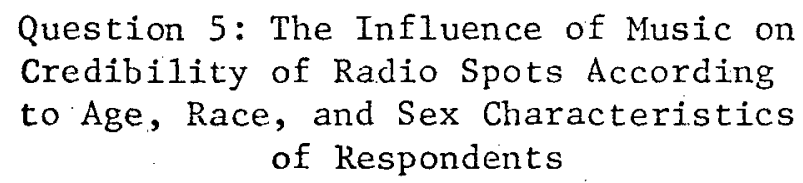

As table 40 shows, several interesting trends emerge in comparing the responses of male and female respondents of white and black races within each age category.

In three of the four age categories, the opinions of white males and white females differ sharply and consistently regarding the influence of music on credibility of radio spots. In the below18 age category, 62 percent of the white female respondents indicated that radio spots with music were the most believable sounding, 
TABLE 40

THE INFLUENCE OF MUSIC ON CREDIBILITY OF RADIO

SPOTS ACCORDING TO AGE, RACE, AND SEX

CHARACTERISTICS OF RESPONDENTS

\begin{tabular}{|c|c|c|c|c|c|c|}
\hline \multirow{2}{*}{$\begin{array}{l}\text { Characteristics of } \\
\text { Respondents }\end{array}$} & \multicolumn{2}{|c|}{$\begin{array}{l}\text { With } \\
\text { Music }\end{array}$} & \multicolumn{2}{|c|}{$\begin{array}{l}\text { Without } \\
\text { Music }\end{array}$} & \multicolumn{2}{|c|}{$\begin{array}{l}\text { No Differ- } \\
\text { ence }\end{array}$} \\
\hline & $\mathrm{N}$ & $\%$ & $\mathrm{~N}$ & $\%$ & $\mathrm{~N}$ & $\%$ \\
\hline Below 18, white, male & 2 & 18 & 6 & 55 & 3 & 27 \\
\hline Below 18, white, female & 8 & 62 & 3 & 23 & 2 & 15 \\
\hline Below 18, black, male & 0 & 0 & 0 & 0 & 0 & 0 \\
\hline Below 18, black, female & 2 & 67 & 0 & 0 & 1 & 33 \\
\hline Below 18, Spanish, male & 0 & 0 & 0 & 0 & 0 & 0 \\
\hline Below 18, Spanish, female & 0 & 0 & 0 & 0 & 0 & 0 \\
\hline Below 18, other, male & 0 & 0 & 0 & 0 & 0 & 0 \\
\hline Below 18, other, female & 0 & 0 & 0 & 0 & 0 & 0 \\
\hline 18-34, white, male & 10 & 28 & 16 & 44 & 10 & 28 \\
\hline 18-34, white, female & 28 & 42 & 19 & 28 & 20 & 30 \\
\hline 18-34, black, male & 6 & 60 & 2 & 20 & 2 & 20 \\
\hline 18-34, black, female & 8 & 53 & 6 & 40 & 1 & 7 \\
\hline 18-34, Spanish, male & 0 & 0 & 0 & 0 & 0 & 0 \\
\hline 18-34, Spanish, female & 0 & 0 & 0 & 0 & 0 & 0 \\
\hline 18-34, other, male & 0 & 0 & 0 & 0 & 0 & 0 \\
\hline 18-34, other, female & 1 & 100 & 0 & 0 & 0 & 0 \\
\hline 35-65, white, male & 9 & 24 & 13 & 34 & 16 & 42 \\
\hline 35-65, white, female & 18 & 29 & 21 & 33 & 24 & 38 \\
\hline 35-65, black, male & 1 & 14 & 5 & 71 & 1 & 14 \\
\hline 35-65, black, female & 5 & 56 & 1 & 11 & 4 & 33 \\
\hline 35-65, Spanish, male & 0 & 0 & 0 & 0 & 0 & 0 \\
\hline 35-65, Spanish, female & 1 & 100 & 0 & 0 & 0 & 0 \\
\hline $35-65$, other, male & 0 & 0 & 0 & 0 & 0 & 0 \\
\hline $35-65$, other, female & 1 & 100 & 0 & 0 & 0 & 0 \\
\hline Above 65, white, male & 3 & 30 & 6 & 60 & 1 & 10 \\
\hline Above 65 , white, female & 5 & 28 & 6 & 33 & 7 & 39 \\
\hline Above 65 , black, male & 1 & 25 & 1 & 25 & 2 & 50 \\
\hline Above 65, black, female. & 1 & 100 & 0 & 0 & 0 & 0 \\
\hline Above 65, Spanish, male & 0 & 0 & 0 & 0 & 0 & 0 \\
\hline Above 65 , Spanish, female & 0 & 0 & 0 & 0 & 0 & 0 \\
\hline Above 65 , other, male & 0 & 0 & 0 & 0 & 0 & 0 \\
\hline Above 65 , other, female & 0 & 0 & 0 & 0 & 0 & 0 \\
\hline
\end{tabular}


whereas 55 percent of the white male respondents indicated that radio spots without music were the most believable sounding. In the 18-34 age category, again the opinions were exactly opposite. While 42 percent of the white females indicated that radio spots with music were the most believable sounding, 44 percent of the male respondents indicated that radio spots without music were the most believable sounding.

In the 35-65 age category, both white males and white females are in close agreement regarding the influence of music on the credibility of radio spots. In both groups there is divided opinion with the largest number of respondents indicating that "It makes no difference."

Again, however, in the above-65 age category, there is sharp disagreement between white males and white females regarding the influence of music on credibility of radio spots. Whereas there is divided opinion among white females in this category, a strong majority ( 60 percent) of the white males indicated that radio spots without music were the most believable sounding.

What was true of the white males and white females in the below-18 age category is true of the black males and black females in the 35-65 age category. In this category, 56 percent of the black females indicated that radio spots with music were the most believable sounding, whereas 71 percent of the black males indicated that radio spots without music were the most believable sounding.

Another significant trend evident in table 40 occurs in the black male category. While 60 percent of the black males in the 
18-34 age category indicated that radio spots with music were the most believable sounding, only 14 percent of the black males in the 35-65 age category indicated this same way and, instead, 7 percent of them indicated that radio spots without music were the most believable sounding. The opinion shift continues into the above-65 age category where the largest number (50 percent) of black males indicated that "It makes no difference."

Apparently, the older the respondent becomes, the less he perceives that the use of music in radio spots contributes to credibility. Additionally, there appears to be a general tendency for female respondents to attribute greater credibility to radio spots with music, whereas male respondents tend to believe that radio spots without music are more credible.

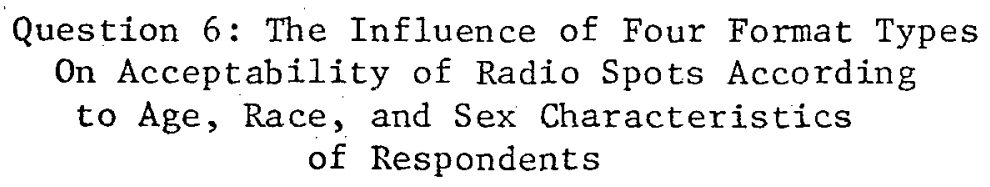

As table 41 shows, the largest number of respondents in most categories of age, race, and sex indicated that they were "most inclined to listen to "Someone telling a personal experience he has had." The greatest margin of preference for this format was in the below-18, white, female category where almost three times as many respondents preferred this format above the other formats. In addition, twice as many respondents in the following categories preferred this format: (1) 35-65, white, male, (2) 35-65, black, female, and (3) above-65, white, female.

The "Announcer reading the script" format was generally the least preferred of the formats. 
TABLE 41

THE INFLUENCE OF FOUR FORMAT TYPES ON ACCEPTABILITY

OF RADIO SPOTS ACCORDING TO AGE, RACE, AND SEX

CHARACTERISTICS OF RESPONDENTS

\begin{tabular}{|c|c|c|c|c|c|c|c|c|c|c|}
\hline \multirow{2}{*}{$\begin{array}{l}\text { Characteristics of } \\
\text { Respondents }\end{array}$} & \multicolumn{2}{|c|}{$\begin{array}{l}\text { Anncr. } \\
\text { Reading }\end{array}$} & \multicolumn{2}{|c|}{$\begin{array}{l}\text { Dia- } \\
\text { logue }\end{array}$} & \multicolumn{2}{|c|}{$\begin{array}{l}\text { Street } \\
\text { Inter- } \\
\text { views }\end{array}$} & \multicolumn{2}{|c|}{$\begin{array}{l}\text { Personal } \\
\text { Experi- } \\
\text { ence }\end{array}$} & \multicolumn{2}{|c|}{$\begin{array}{l}\text { No Dif- } \\
\text { ference }\end{array}$} \\
\hline & $\mathrm{N}$ & $\%$ & $\mathrm{~N}$ & $\%$ & $\mathrm{~N}$ & $\%$ & $\mathrm{~N}$ & $\%$ & $\mathrm{~N}$ & $\%$ \\
\hline elow 18 , white, male & 2 & 18 & 3. & 27 & 4 & 36 & 2 & 18 & 0 & 8 \\
\hline elow 18 , white, female & 0 & 0 & 1 & 8 & 3 & 23 & 8 & & 1 & 8 \\
\hline Below 18, black, male & 0 & 0 & 0 & 0 & 0 & 0 & 0 & 0 & 0 & 0 \\
\hline Below 18, b1ack, female & 1 & 33 & 0 & 0 & 1 & 33 & 1 & 33 & 0 & 0 \\
\hline Below 18, Spanish, male & 0 & 0 & 0 & 0 & 0 & 0 & 0 & 0 & 0 & 0 \\
\hline Below 18, Spanish, female & 0 & 0 & 0 & 0 & 0 & 0 & 0 & 0 & 0 & 0 \\
\hline Below 18 , other, male & 0 & 0 & 0 & 0 & 0 & 0 & 0 & 0 & 0 & 0 \\
\hline Below 18, other, female & 0 & 0 & 0 & 0 & 0 & 0 & 0 & 0 & 0 & 0 \\
\hline 18-34, white, male & 8 & 22 & 9 & & 7 & 1 & & & & 6 \\
\hline 18-34, white, female & 10 & 15 & 14 & 21 & 14 & 21 & 24 & 36 & 5 & 7 \\
\hline 18-34, black, male & 0 & 0 & 5 & 50 & 1 & 10 & 2 & 20 & 2 & 20 \\
\hline 18-34, black, female & 1 & 7 & 3 & 20 & 4 & 27 & 6 & 40 & 1 & 7 \\
\hline 18-34, Spanish, male & 0 & 0 & 0 & 0 & 0 & 0 & 0 & 0 & 0 & 0 \\
\hline 18-34, Spanish, female & 0 & 0 & 0 & 0 & 0 & 0 & c & 0 & 0 & 0 \\
\hline 18-34, other, male & 0 & 0 & 0 & 0 & 0 & 0 & c & 0 & 0 . & 0 \\
\hline 18-34, other, female & 0 & 0 & 0 & 0 & 0 & 0 & 1 & 100 & 0 & 0 \\
\hline 35-65, white, male & 7 & 18 & 5 & & 6 & 16 & 18 & 4 & 2 & 5 \\
\hline 35-65, white, female & 9 & 14 & 12 & 1. & 7 & 11 & 28 & 44 & 7 & 11 \\
\hline 35-65, black, male & 1 & 14 & $' 1$ & 1 & 2 & 29 & 3 & 4 & 0 & 0 \\
\hline 35-65, black, fèmale & 0 & 0 & 2 & 22 & 2 & 22 & 5 & 56 & 0 & 0 \\
\hline 35-65, Spanish, male & 0 & 0 & 0 & 0 & 0 & 0 & 0 & 0 & 0 & 0 \\
\hline 35-65, Spanish, female & 0 & 0 & 0 & 0 & 0 & 0 & 1 & 100 & 0 & 0 \\
\hline $35-65$, other, male & 0 & 0 & 0 & 0 & 0 & 0 & 0 & 0 & 0 & 0 \\
\hline 35-65, other, female & 0 & 0 & 0 & 0 & 0 & 0 & 1 & 100 & 0 & 0 \\
\hline Above 65 , white, male & 1 & 10 & 4 & 40 & & & & & 0 & 0 \\
\hline Above 65 , white, female & 2 & 11 & 1 & 6 & 5 & 28 & 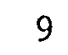 & 5 & 1 & 6 \\
\hline Above 65 , black, male & 0 & 0 & 1 & 25 & 1 & 25 & 1 & 25 & 1 & 25 \\
\hline Above 65 , black, female & 0 & 0 & 0 & 0 & 0 & 0 & 0 & 0 & 1 & 100 \\
\hline Above 65 , Spanish, male & 0 & 0 & 0 & 0 & 0 & 0 & 0 & 0 & 0 & 0 \\
\hline Above 65, Spanish, female & 0 & 0 & 0 & 0 & 0 & 0 & 0 & 0 & 0 & 0 \\
\hline Above 65 , other, male & 0 & 0 & 0 & 0 & 0 & 0 & 0 & 0 & 0 & 0 \\
\hline Above 65 , other, female & 0 & 0 & 0 & 0 & 0 & 0 & 0 & 0 & 0 & 0 \\
\hline
\end{tabular}


The dialogue format ("Two people talking to each other") was the generally, preferred format only of the 18-34, black, male category. However, respondents in the above-65, white, male and above-65, black, male categories indicated an equal preference for that format and at least one other.

The "on-the-street interviews" format was preferred by the largest number of respondents in the below-18, white, male category. Only 18 percent of the male respondents in this category preferred the "personal experience" format, whereas 62 percent of the female respondents in this category preferred the "personal experience" format.

\section{Question 7: The Influence of Four Fornat Types on Credibility of Radio Spots According to Age, Race, and Sex Characteristics of Respondents}

As table 42 shows, the largest number of respondents in most categories of age, race, and sex indicated that the most believable sounding format was "Someone telling a personal experience he has had." The largest number of respondents attributing the greatest amount of credibility to this format were in the following categories: (1) 35-65, white, female, (2) 35-65, black, male, and (3) 35-65, black, female.

\section{Question 8: The Influence of Three Types of Communicators on Acceptability of Radio Spots According to Age, Race, and Sex Characteristics of Respondents}

As table 43 shows, in general, the younger the respondents, the greater their preference for the "any Christian" conmunicator type, in terms of credibility. However, as the age of the 
TABLE 42

THE INFLUENCE OF FOUR FORMAT TYPES ON CREDIBILITY OF RADIO SPOTS ACCORDING TO AGE, RACE AND SEX CHARACTERISTICS OF RESPONDENTS

\begin{tabular}{|c|c|c|c|c|c|c|c|c|c|c|}
\hline \multirow{2}{*}{$\begin{array}{l}\text { Characteristics of } \\
\text { Respondents }\end{array}$} & \multicolumn{2}{|c|}{$\begin{array}{l}\text { Anncr. } \\
\text { Reading }\end{array}$} & \multicolumn{2}{|c|}{$\begin{array}{l}\text { Dia- } \\
\text { logue }\end{array}$} & \multicolumn{2}{|c|}{$\begin{array}{l}\text { Street } \\
\text { Inter- } \\
\text { views }\end{array}$} & \multicolumn{2}{|c|}{$\begin{array}{l}\text { Personal } \\
\text { Experi- } \\
\text { ence }\end{array}$} & \multicolumn{2}{|c|}{$\begin{array}{l}\text { No Dif- } \\
\text { ference }\end{array}$} \\
\hline & $\mathrm{N}$ & $\%$ & $\mathrm{~N}$ & $\%$ & $\mathrm{~N}$ & $\%$ & $\mathrm{~N}$ & $\%$ & $\mathrm{~N}$ & $\%$ \\
\hline Below 18, white, male & 1 & 9 & 2 & 18 & 3 & 27 & 5 & 45 & 0 & 0 \\
\hline Below 18, white, female & 0 & 0 & 3 & 23 & 4 & 31 & 4 & 31 & 2 & 15 \\
\hline Below 18, black, male & 0 & 0 & 0 & 0 & 0 & 0 & 0 & 0 & 0 & 0 \\
\hline Below 18, black, female & 1 & 33 & 0 & 0 & 2 & 67 & 0 & 0 & 0 & 0 \\
\hline Below 18, Spanish, male. & 0 & 0 & 0 & 0 & 0 & 0 & 0 & 0 & 0 & 0 \\
\hline Below 18, Spanish, female & 0 & 0 & 0 & 0 & 0 & 0 & 0 & 0 & 0 & 0 \\
\hline Below 18 , other, male & 0 & 0 & 0 & 0 & 0 & 0 & 0 & 0 & 0 & 0 \\
\hline Below 18 , other, female & 0 & 0 & 0 & 0 & 0 & 0 & 0 & 0 & 0 & 0 \\
\hline 18-34, white, male & 7 & 19 & 8 & 22 & 8 & 22 & 10 & 28 & 2 & 6 \\
\hline 18-34, white, female & 5 & 7 & 11 & 16 & 18 & 27 & 29 & 43 & 4 & 6 \\
\hline 18-34, black, male & 1 & 10 & 3 & 30 & 0 & 0 & 4 & 40 & 2 & 20 \\
\hline 18-34, black, female & 1 & 7 & 3 & 20 & 4 & 27 & 7 & 47 & 0 & 0 \\
\hline 18-34, Spanish, male & 0 & 0 & 0 & 0 & 0 & 0 & 0 & 0 & 0 & 0 \\
\hline 18-34, Spanish, female & 0 & 0 & 0 & 0 & 0 & 0 & 0 & 0 & 0 & 0 \\
\hline $18-34$, other, male & 0 & 0 & 0 & 0 & 0 & 0 & 0 & 0 & 0 & 0 \\
\hline 18-34, other, female & 0 & 0 & 0 & 0 & 0 & 0 & 1 & 100 & 0 & 0 \\
\hline 35-65, white, male & 7 & 18 & 2 & 5 & 9 & 24 & 15 & 39 & 5 & 13 \\
\hline 35-65, white, female & 10 & 16 & 10 & 16 & 3 & 5 & 35 & 56 & 5 & 8 \\
\hline $35-65$, black, male & 1 & 14 & 1 & 14 & 1 & 14 & 4 & 57 & 0 & 0 \\
\hline $35-65$, black, female & 1 & 11 & 0 & 0 & 2 & 22 & 6 & 67 & 0 & 0 \\
\hline 35-65, Spanish, male & 0 & 0 & 0 & 0 & 0 & 0 & 0 & 0 & 0 & 0 \\
\hline 35-65, Spanish, female & 0 & 0 & 0 & 0 & 1 & 100 & 0 & 0 & 0 & 0 \\
\hline 35-65, other, male & 0 & 0 & 0 & 0 & 0 & 0 & 0 & 0 & 0 & 0 \\
\hline 35-65, other, female & 0 & 0 & 0 & 0 & 1 & 100 & 0 & $0^{\circ}$ & 0 & 0 \\
\hline Above 65 , white, male & 2 & 20 & 4 & 40 & 1 & 10 & 3 & 30 & 0 & 0 \\
\hline Above 65 , white, female & 2 & 11 & 2 & 11 & 2 & 11 & 8 & 44 & 4 & 22 \\
\hline Above 65 , black, male & 2 & 50 & 0 & 0 & 1 & 25 & 0 & 0 & 1 & 25 \\
\hline Above 65 , black, female & 0 & 0 & 0 & 0 & 0 & 0 & 1 & 100 & 0 & 0 \\
\hline Above 65, Spanish, male & 0 & 0 & 0 & 0 & 0 & 0 & 0 & 0 & 0 & 0 \\
\hline Above 65 , Spanish, female & 0 & 0 & 0 & 0 & 0 & 0 & 0 & 0 & 0 & 0 \\
\hline Above 65 , other, male & 0 & 0 & 0 & 0 & 0 & 0 & 0 & 0 & 0 & 0 \\
\hline Above 65 , other, female & 0 & 0 & 0 & 0 & 0 & 0 & 0 & 0 & 0 & 0 \\
\hline
\end{tabular}


TABLE 43

THE INFLUENCE OF THREE TYPES OF COMMUNICATORS ON ACCEPTABILITY OF RADIO SPOTS ACCORDING TO

AGE, RACE, AND SEX CHARACTERISTICS

OF RESPONDENTS

\begin{tabular}{|c|c|c|c|c|c|c|c|c|}
\hline \multirow{2}{*}{$\begin{array}{l}\text { Characteristics of } \\
\text { Respondents }\end{array}$} & \multicolumn{2}{|c|}{$\begin{array}{l}\text { Commen- } \\
\text { tator }\end{array}$} & \multicolumn{2}{|c|}{ Pastor } & \multicolumn{2}{|c|}{$\begin{array}{l}\text { Any } \\
\text { Christian }\end{array}$} & \multicolumn{2}{|c|}{$\begin{array}{l}\text { No Dif- } \\
\text { ference }\end{array}$} \\
\hline & $\mathrm{N}$ & $\%$ & $\mathrm{~N}$ & $\%$ & $\mathrm{~N}$ & $\%$ & $\mathrm{~N}$ & $\%$ \\
\hline Below 18, white, male & 2 & 18 & 1 & 9 & 7 & 64 & 1 & 9 \\
\hline Below 18, white, female & 0 & 0 & 3 & 23 & 10 & 77 & 0 & 0 \\
\hline Below 18, black, male & 0 & 0 & 0 & 0 & 0 & 0 & 0 & 0 \\
\hline Below 18, black, female & 0 & 0 & 1 & 33 & 2 & 67 & 0 & 0 \\
\hline Below 18, Spanish, male & 0 & 0 & 0 & 0 & 0 & 0 & 0 & 0 \\
\hline Below 18, Spanish, female & 0 & 0 & 0 & 0 & 0 & 0 & 0 & 0 \\
\hline Below 18 , other, male & 0 & 0 & 0 & 0 & 0 & 0 & 0 & 0 \\
\hline Below 18 , other, female & 0 & 0 & 0 & 0 & 0 & 0 & 0 & 0 \\
\hline 18-34, white, male & 12 & 33 & 8 & 22 & 11 & 31 & 5 & 14 \\
\hline 18-34, white, female & 7 & 10 & 17 & 25 & 35 & 52 & 8 & 12 \\
\hline 18-34, black, male & 1 & 10 & 0 & 0 & 6 & 60 & 3 & 30 \\
\hline 18-34, black, female & 1 & 7 & 5 & 33 & 9 & 60 & 0 & 0 \\
\hline 1.8-34, Spanish, male. & 0 & 0 & 0 & 0 & 0 & 0 & 0 & 0 \\
\hline 18-34, Spanish, female & 0 & 0 & 0 & 0 & 0 & 0 & 0 & 0 \\
\hline 18-34, other, male & 0 & 0 & 0 & 0 & 0 & 0 & 0 & 0 \\
\hline 18-34, other, female & 0 & 0 & 1 & 100 & 0 & 0 & 0 & 0 \\
\hline 35-65, white, male & 5 & 13 & 13 & 34 & 16 & 42 & 4 & 11 \\
\hline 35-65, white, female & 7 & 11 & 23 & 37 & 27 & 43 & 6 & 10 \\
\hline 35-65, black, male & 1 & 14 & 5 & 71 & 1 & 14 & 0 & 0 \\
\hline 35-65, black, female & 0 & 0 & 7 & 78 & 2 & 22 & 0 & 0 \\
\hline 35-65, Spanish, male & 0 & 0 & 0 & 0 & 0 & 0 & 0 & 0 \\
\hline 35-65, Spanish, female & 0 & 0 & 1 & 100 & 0 & 0 & 0 & 0 \\
\hline $35-65$, other, male & 0 & 0 & 0 & 0 & 0 & 0 & 0 & 0 \\
\hline $35-65$, other, female & 0 & 0 & 0 & 0 & 1 & 100 & 0 & 0 \\
\hline Above 65 , white, male & 0 & 0 & 4 & 40 & 3 & 30 & 3 & 30 \\
\hline Above 65 , white, female & 0 & 0 & 12 & 67 & 4 & 22 & 2 & 11 \\
\hline Above 65, black, male & 0 & 0 & 4 & 100 & 0 & 0 & 0 & 0 \\
\hline Above 65 , black, female & 0 & 0 & 0 & 0 & 0 & 0 & 0 & 100 \\
\hline Above 65, Spanish, male & 0 & 0 & 0 & 0 & 0 & 0 & 0 & 0 \\
\hline Above 65 , Spanish, female & 0 & 0 & 0 & 0 & 0 & 0 & 0 & 0 \\
\hline Above 65 , other, male & 0 & 0 & 0 & 0 & 0 & 0 & 0 & 0 \\
\hline Above 65 , other, female & 0 & 0 & 0 & 0 & 0 & 0 & 0 & 0 \\
\hline
\end{tabular}


respondents increases, the greater becomes their preference for the "pastor" communicator type, in terms of credibility.

This trend is particularly evident in all age categories of white females, as will be noted in the following sequence. In the below-18, white, female category, 77 percent preferred the "any Christian" communicator type, in terms of credibility. In the 18-34, white, female category, 52 percent of the respondents preferred the "any Christian" communicator type. In the 35-65, white, female category, 43 percent preferred the "any Christian" communicator type. Finally, in the above-65, white, female category, only 22 percent preferred the "any Christian" communicator type, while 67 percent of the respondents preferred the "pastor" communicator type, in terms of crediblity.

The strongest preference, in terms of credibility, for "any Christian" shows up in the following categories: (1) below-18, white, male, (2) below 18, white, female, and (3) above-65, white, female.

The strongest credibility attributed to the "pastor" communicator type shows up in the following categories: (1) 35-65, black, male, (2) 35-65, black, female, (3) above-65, white, female, and

(4) above 65, black, male.

The "commentator" communicator type is not generally preferred by the respondents, in terms of credibility.

Question 9: The Influence of Three Types of Communicators on Credibility of Radio Spots According to Age, Race and Sex Characteristics of Respondents

As table 44 shows, the trend of responses in all demographic categories is similar to that in table 43. In other words, that type 
TABLE 44

THE INFLUENCE OF THREE TYPES OF COMMUNICATORS ON CREDIBILITY OF RADIO SPOTS ACCORDING TO AGE, RACE, AND SEX CHARACTERISTICS

OF RESPONDENTS

\begin{tabular}{|c|c|c|c|c|c|c|c|c|}
\hline \multirow{2}{*}{$\begin{array}{l}\text { Characteristics of } \\
\text { Respondents }\end{array}$} & \multicolumn{2}{|c|}{$\begin{array}{l}\text { Commen- } \\
\text { tator }\end{array}$} & \multicolumn{2}{|c|}{ Pastor } & \multicolumn{2}{|c|}{$\begin{array}{l}\text { Any } \\
\text { Christian }\end{array}$} & \multicolumn{2}{|c|}{$\begin{array}{l}\text { No Dif- } \\
\text { ference }\end{array}$} \\
\hline & $\mathrm{N}$ & $\%$ & $\mathrm{~N}$ & $\%$ & $\mathrm{~N}$ & $\%$ & $\mathrm{~N}$ & $\%$ \\
\hline Below 18 , white, male & 0 & 0 & 4 & 36 & 7 & 64 & 0 & 0 \\
\hline Below 18 , white, female & 0 & 0 & 4 & 31 & 7 & 54 & 2 & 15 \\
\hline Below 18, black, male & 0 & 0 & 0 & 0 & 0 & 0 & 0 & 0 \\
\hline Below 18, black, female & 0 & 0 & 0 & 0 & 3 & 100 & 0 & 0 \\
\hline Below 18, Spanish, male. & 0 & 0 & 0 & 0 & 0 & 0 & 0 & 0 \\
\hline Below 18, Spanish, female & 0 & 0 & 0 & 0 & 0 & 0 & 0 & 0 \\
\hline Below 18 , other, male & 0 & 0 & 0 & 0 & 0 & 0 & 0 & 0 \\
\hline Below 18 , other, female & 0 & 0 & 0 & 0 & 0 & 0 & 0 & 0 \\
\hline 18-34, white, male & 8 & 22 & 13 & 36 & 12 & 33 & 3 & 8 \\
\hline 18-34, white, female & 3 & 4 & 21 & 31 & 35 & 52 & 8 & 1.2 \\
\hline 18-34, black, male & 2 & 20 & 2 & 20 & 5 & 50 & 1 & 10 \\
\hline 18-34, black, female & 0 & 0 & 7 & 47 & 8 & 53 & 0 & 0 \\
\hline 18-34, Spanish, male & 0 & 0 & 0 & 0 & 0 & 0 & 0 & 0 \\
\hline 18-34, Spanish, female & 0 & 0 & 0 & 0 & 0 & 0 & 0 & 0 \\
\hline 18-34, other, male & 0 & 0 . & 0 & 0 & 0 & 0 & 0 & 0 \\
\hline 18-34, other, female & 0 & 0 & 1 & 100 & 0 & 0 & 0 & 0 \\
\hline 35-65, white, male & 3 & 8 & 11 & 29 & 18 & 47 & 6 & 16 \\
\hline 35-65, white, female & 2 & 3 & 20 & 32 & 30 . & 48 & 11 & 18 \\
\hline $35-65$, black, male & 1 & 14 & 4 & 57 & 1 & 14 & 1 & 14 \\
\hline 35-65, black, female & 0 & 0 & 7 & 78 & 2 & 22 & 0 & 0 \\
\hline 35-65, Spanish, male & 0 & 0 & 0 & 0 & 0 & 0 & 0 & 0 \\
\hline 35-65, Spanish, female & 0 & 0 & 1 & 100 & 0 & 0 & 0 & 0 \\
\hline $35-65$, other, male & 0 & 0 & 0 & 0 & 0 & 0 & 0 & 0 \\
\hline $35-65$, other, female & 0 & 0 & 0 & 0 & 0 & 0 & 0 & 0 \\
\hline Above 65 , white, male & 1 & 10 & 5 & 50 & 2 & 20 & 2 & 20 \\
\hline Above 65 , white, female & 1 & 6 & 11 & 61 & 2 & 11 & 4 & 22 \\
\hline Above 65, black, male & 0 & 0 & 4 & 100 & 0 & 0 & 0 & 0 \\
\hline Above 65 , black, female & 1 & 100 & 0 & 0 & 0 & 0 & 0 & 0 \\
\hline Above 65, Spanish, male & 0 & 0 & 0 & 0 & 0 & 0 & 0 & 0 \\
\hline Above 65 , Spanish, female & 0 & 0 & 0 & 0 & 0 & 0 & 0 & 0 \\
\hline Above 65 , other, male & 0 & 0 & 0 & 0 & 0 & 0 & 0 & 0 \\
\hline Above 65 , other, female & 0 & 0 & 0 & 0 & 0 & 0 & 0 & 0 \\
\hline
\end{tabular}


of communicator who is perceived to be most acceptable is also generally perceived to be most credible.

\section{Summary}

There were 311 nominal and non-Christians in the Benton Harbor-St. Joseph, Michigan area surveyed by phone to discover which of the most commonly used radio spot formats contribute most to the acceptability and credibility of radio spots.

The largest number of those surveyed were white, female, age 18-34, living in Benton Harbor, with a 3-nominal Christian rating on the numbered scale $\left(\begin{array}{llllll}0 & 1 & 2 & 3 & 4 & 5\end{array}\right)$.

The survey found that the most acceptable type of radio spot for most nominal and non-Christians includes (1) the use of music, (2) "someone telling a personal experience he has had," and (3) when Christianity is presented, "any Christian telling why he is one."

It was also found that the most credible type of radio spot for most nominal and non-Christians has the same characteristics as the most acceptable type, with but one exception. There appears to be no clear-cut opinion regarding whether or not the use of music affects the credibility of a radio spot.

\section{Conclusion}

The results of this study illustrate that different respondents have different preferences (in terms of acceptability and credibility) for radio spot formats and production techniques. Therefore, a variety of radio spots approaches directed toward a wide spectrum of listener preferences seems justified. 
Nevertheless, the researcher's present concern was to discover which of the most commonly used radio production formats contribute most to acceptability and credibility of religious radio spots whose intended audience is either nominal or non-Christian, and to produce a thirteen-week, series of daily, public-service radio spots for evangelistic purposes based on this determination.

For that reason, the researcher included the following production elements in his series of evangelistic radio spots: (1) music, (2) "Someone telling a personal experience he has had," and (3) "Any Christian telling why he is one." In many cases, "the second and third elements" overlapped or coincided in actual production. (See "An On-Paper Radio Spot Model," p. 119).

\section{Recommendations}

(1) A replication of this survey in another geographical location other than southwestern Michigan (Benton Harbor-St. Joseph area) might contribute meaningfully to an increase in the generalizability of the survey results.

(2) A replication of the survey including persons identifying themselves by either a 4 or 5 on the scale of relative interest in Christianity (question 3) might be useful in determining any differences in responses between nominal and non-Christians, and Christians.

(3) Further analysis of the data gathered would be useful in determining with more detailed accuracy the statistical significance of the results of the study, which at present have been presented and subjectively interpreted on the basis of frequencies and percentages. 
AN ON-PAPER RADIO SPOT MODEL

Based on the Results of the Survey

Theme music up then under and out

Announcer: "Turning Point . . . sixty seconds of contrast."

"SOMEONE TELLING A PERSONAL

EXPERIENCE HE HAS HAD"

Theme music up then under

Announcer: "Turning Point . . worth a second thought...

from the Seventh-day Adventist Church."

Theme music up and out 


\section{APPENDIX A}

\section{Procedures and Results of the Interview}

Session of June 22, 1976 
Preliminary. "On-the-street" Interviews

Objective: To get creative ideas for questions for the mail questionnaire

Technique: Open-ended questions

Location: Fairplain Plaza, Benton Harbor, Michigan

Date and Time: June 22, 1976, 2:45-5:00 p.m.

\section{Typical Procedure}

1. Introduction: "Hi. I'm with WAUS radio."

2. Immediate question: "Do you listen to sports on the radio?"

(Note: the purpose of this question is to lessen the probability of initial prejudice which might otherwise result from the mention of religion).

3. Follow-up question: "Why do you listen to sports/ why don't you? etc."

4. Secondary question: "When these short religious messages--1ike commercials--come on the air between music cuts, are you more inclined to listen to them, or to not listen to them?"

5. Follow-up question: "Why? What really turns you on/off about these short religious messages?"

Interview 1: Prefers thought-provoking messages.

Interview 2: Prefers "something that's kinda inspirational or makes you stop and think."

Interview 3: Turned off by religious messages because of people "all the time talkin' about things you should do and shouldn't do and all that. That's what just turns me off. I just do what I wanna do."

Interview 4: Thinks religious messages on radio are important to our society and "gives us something good to think about. ..." Prefers spots that "are brief and to the point, that have something truthful to say and they say it in a concise manner, and get the message over in a brief amount of time."

Interview 5: Likes to listen to them because she is already a Christian and is seeking more understanding of the Bible. Doesn't like "religious" spoțs which "don't believe in God or Jesus" because she does.

Interview 6: Listens to religious spots because I'm religious." Likes to listen to preachers who have something to say; current events.

Interview 7: Doesn't like it if it pertains to one sect. Prefers someone talking as opposed to singing because it "seems more plausible." If it's singing, I don't think it's "on the up-and-up." 
Interview 9: Listens because he is religious himself. Doesn't like "old fashioned" spots, i.e., "someone talking about your hair being too long or whatever. That kinda thing turns me off."

Prefers talking spot.

Interview 10: No opinion, listens to anything.

Interview 11: Doesn't listen because "I'm an atheist.".

Interview 12: Likes to listen to religion on the radio for explanation of things in the Bible. Prefers to be "asked" to do something rather than to be "made" to do it.

Interview 13: Likes to Iisten to them because they have a bearing on a person.

Interview 14: Likes to 1isten to become aware of other religious bodies, and "it gives you a chance to see what other churches are like."

Interview 15: "I 1isten for what he's got to say. It's not so much the music. It's what he's got to say."

Interview 16: Decision to listen or not depends on "what they say." More inclined to listen to the spot if there is music with the spot.

Interview 17: More inclined to "turn the dial" because he wants something "more in talk and music and stuff like that." "I don't get interested in it when other stuff is there. That's the only thing."

Interview 18: Sometimes listens "if near the radio. But we have our own church we go to."

What would it take for a religion spot to really grab your attention? "If I were to hear Bishop Sheen, if I heard his voice, then I listen to him." An authority figure, in other words?

"Yeah. Um-Hummm."

Interview 19: Doesn't know what it would take to grab her attention.

Interview 20: Listens because. "I guess that's as much a part of me as sports is, too." What kind of religious spots really turn you on? "I think something that's musical, religious music."

Interview 21: Likes to listen to the Watch Tower program because of what "the guy has to say, and how the music fits into the style of the program." Says music helps to break up the monotony of the sermon. And: "You know, the 
songs that they play during the thing have something to do with the sermon or the thing they're trying to get across."

Interview 22: I haven't heard one.

Interview 23: "The talk" turns him off. "You're used to something bold on when you're listening to radio. Then all of a sudden, you hear a little old man saying, 'Now God is gonna say this, or God is gonna do this. And you know, it really doesn't fit into it. It's like going from a rock to an easy-listening station. You can tell the difference, you know. And that kinda turns you off. It doesn't fit."

Interview 24: Listens to it just because it's on.

Interview 25: Thinks it's "inappropriate for it to come in between music anyway." Should be played "in the hours set aside for that." "You're listening to music and it breaks your train of thought."

Interview 26: Hasn't heard one because he listens to FM (?). Must "ring true."

Interview 27: A big name would grab his attention. (Interviewee 26) The only way you can tell if a spot "rings true" is "you know that in your heart"--"You'd know it rang true if it, you know, had something to do with love, something to do with love without sounding clichish. There are big cliche monsters all over."

Interview 28: Listens to WKZO, hears them on that station right after the news. Prefers something more of a general concern, not sect oriented. Dealing with some of the Scriptures, some of the commandments, something in that vein, rather "than emphasizing some particular religion."

Interview 29: What turns you off about these little religious messages that come on? "It depends on what day it's on. If it ain't on Sunday, I just turn it off." Turned off because she's "not in the mood for hearing a religious spot." To grab her attention, it would have to have music in it, "good music."

Interview 30: "I might not 1isten to it, but I'd probably wouldn't change the dial." Would be more inclined to listen if it were a "talking spot" than a "singing spot." Prefers dialogue.

Interview 31: Listens because he finds some of them interesting. Particularly likes the positive note about them "and I 
enjoy that." He enjoys 1istening, but "it doesn't really grab me." Doesn't think it would be possible for himself to become involved in a religious radio announcement.

Interview 32: Objects to the type that attempts to force somebody else's idea of religion "as opposed to what my views are." "Any messages that would be in accordance or in line with my feelings of religion would be perfectly acceptable to me." Should stick with generalities of the Bible, rather than going into specifics of the Bible, into interpretation, and applied to one particular religion. "I think generalities would probably be acceptable by most people."

Interview 33: "Oh, I listen to 'em. I don't even bother to turn the channe1." "If I know it's not gonna be a long deal, I'11 keep it on." Prefers something "that isn't too much preaching. It has to be something that's easy to listen to, too. Pleasant voice, for instance. Something along that line." Prefers something that would tie in "with my everyday life, you know what I mean. - . Not necessarily readings out of the Bible. Maybe other things relating to the Bible, but, you know, tie it in with the regular life. Like take troubles, problems in everyday life and relate them back to problems that people in the Bible had, you know." Doesn't like "that real preachy stuff."

Interview 34: Listens to them on CBS, "cause they come over the CBS radio, and I have the CBS radio on all the time." Don't like nothin' but religion songs. . . I'm a religious man, and I like to listen to it."

Interview 35: "Oh, I listen. I take them along with the other programs. Don't pay any special attention to them. Yeah, I listen to them. I don't turn them off or pick up a book or anything. I just stay with it." None of them sound more credible than others. I'm "an Episcopalean to begin with."

Interview 36: "I suppose what it does. It goes in one ear, and out the other." Believes modern man worships the State, not the Church.

Interview 37: "I 1isten to al1 religious beliefs and sayin's." "I guess because I'm Protestant, I like to hear something in that field." Prefers "straight announcer" over interviews, dialogues.

Interview 38: "If it's there, I listen to it. I might not comprehend what it's saying, but by it's bein' there, I just listen to it." Likes "Jubilee" radio program in 
Chicago, black spiritual church music. "I dig music more than I dig talking to folks."

Interview 39: Listens because he's a Christian, and belongs to a church, and believes in God and Jesus Christ, "that's way." Likes to listen because there's something that's been put in him by the Lord. "If you'd have all the money in the world, and offer me anything I want, I'd take God, my Saviour, cause we's just here for a little while and then we're gone. Then we're gone for eternity. So--the second chance I don't want. I want to be ready in the first one, you see."

Interview 40: Doesn't listen because he's "not into religion." Practical, vital.

Interview 41: Listens to WAUS. A lot of good things on Saturday. "I think there' $d$ just have to be an interest in the person himself beforehand he'd actually listen to it." (Interviewee 40): Would listen to "dynamite jazz, sex, anything to grab the attention of the masses." (Interviewee 41, again): To grab people's attention, it would have to be "something practical to everybody . . . normal, everyday problems people have."

Interview 42: Listens to WAUS, because "it's a religious station." "I kinda think there should be more of it, myself." "If you're listening to the radio, you're listening to everything that's on it. You don't just up and turn the channel." Listens to religious spots "because I.'m more or less religious myself in the first place."

Interview 43: Doesn't 1isten to religious spots, because she turns on the radio to listen to the music--"that's what the radio's for." The short religious messages "don't bother me if they're short, whatever." Feels that she might be. more inclined to listen to religious messages if they were "something that made you think." Prefers "just regular speaking" over singing or dialogue spots.

Interview 44: Listens to them "cause I've heard a lot of interesting comments on them, I guess, is why." "I don't go to church often, and I just hear a lot of good points on there, day-to-day living that I just think are good to know."

Interview 45: Listens to them "because I'm a very religious person, and I like them, what they have to say." Prefers spots which remind people to go to church, "which they don't do much of nowdays." Likes spots about "being cheerful and having a good outlook." 
Interview 46: Listens "to what they have to say, because what they have to say--they usually mean it, you know, it's usually something important, or they wouldn't be sticking it in there." A lot of times they sound "kinda corny." But to sound good, and real, it should sound like they're saying it on our level... not speaking religiously, but, using analogies to regular 1ife."

Interview 47: Listens to them subconsciously. "You're not thinking, but, I mean, it's coming in your brain you know, you're soaking it in. And a lot of people can use it--me included." "I don't want them to yell at me, and they shouldn't talk too softly or I'm not going to hear it." Prefers music with the spots. "Music always helps me with everything."

Interview 48: Listens to them "if I'm not doing anything else."

Content would grab her, like "these religious preachers where you have to pay for your prayers." Sarcasm, tone of voice would grab her attention. Would sound authoritative if it were a quote from the Bible, someone with "sternness in his voice, knows what he's talking about."

Interview 49: Listens to them and "I'd say, 8 times outa 10 it generally strikes home." Must be "right to the point." Gotta have "a little bit of feeling. Nowadays, you gotta have a little joke in there. You gotta bend with the tide, or bend with the waves."

Interview 50: Listens "cause it's what I guess we need to know." Likes to listen to Pentecostal spots. Prefers music with the spots.

Interview 51: Likes to 1isten because he gets a lot of "inspirement" out of them. Listens because "actually I'm from a religious family. And the more religion $I$ hear on the radio, the better I feel, really." 
SUMMARY INDICATORS AND CONCLUSIONS FROM INFORMAL ON-THE-STREET INTERVIEWS: June 22, 1976

\section{Clarification Necessary}
A. What is a "spot" or "short religious message" or "commercial" or "announcement." Preferred: "Short religlous commercial"
B. Make distinction between singing and music spot (music with talk--instrumental, vocal--just musical instruments.
c. Criteria for "credible" and "authoritative."

\section{Preference Reaction Areas for Rellgious Spots}

A. "Thought-provoking" $1,2,4,6,15,16,21,43,44$

B. "Inspirational" 2

C. "Brlef and to-the-Point" 4,8,49

D. Because Christian him/herself $5,6,8,9,17,20,34,39,42,45,51$

E. Seeking more information from Bible $5,12,28$

F. "Current events" 6

G. Prefers talking over singing spot 7--"seems more plausible"-$9,30,37-$ "straight announcer"--43

H. "Tells it like it is" 8

I. Listens to anything, everthing, just because it's on 10,24, $30,33,34,35,37,38,42,47$

J. Practical, everyday living (problems, troubles, etc.) 13,33 $40,41,44,45,46$

K. To become aware of other religious bodies 14

L. Listens for talking more than music accompaniment 15

M. Prefers music with the talking spot $16,20,21,29,47,50$

N. Authority figure (1.e. Bishop Sheen) 18,27

o. Music should be appropriate to message 21

P. Must "ring true" 26

Q. Rings true if it has to do with love 26

R. Prefers more general spot 28,32

S. Prefers dialogue 30 
T. Likes positive note 31

U. Likes pleasant voice 33

v. Prefers singing spot 38

W. Dynamite jazz, sex 40

X. Prefers spots which remind people to go to church 45

Y. Credibility fust because on radio 46,50

Z. Use analogies 46

z1. Tone of voice 48

22. Sarcasm 48

23. Sterness in voice 48

24. Quotes from the Bible 48

25. Feeling needed 49

26. Joke needed 49

III. Negative Reaction Areas to Religious Spots
A. "Telling me what I should do and not do" (Didacticism) 3,9,12,32
B. Spots which "don't belleve in God or Jesus" 5
c. Pertaining to one sect $7,28,32$
D. "Old Fashioned" spots 9
E. Because he's an atheist 11,40 (goes with IID--Lifestyle belief)
F. Tuned in to hear something else $17,25,43$ "inappropriate"
G. Not relevant to what you're listening for and how living 23
"little old man comes in preaching"
H. If not heard on Sunday, turned off
I. Doesn't like to be preached at 33
J. Doesn't like readings out of the Bible 33
k. Goes in one ear and out the other 36
L. Kinda corny 46
M. Don't say it "religiously" 46 
APPENDIX B

Questionnaire Used in the Interview

Session of June 29, 1976 
RADIO LISTENER SURVEY

Andrews University

"On-the-street" Interviews

June 29, 1976

1. Where on this scale would you put "enthusiastic" sports fans?

$\begin{array}{llllll}0 & 1 & 2 & 3 & 4 & 5\end{array}$

Where on this scale would you put "take-it-or-leave-it" fans?

012345

2 . Where on this scale would you put people who vote regularly?

$\begin{array}{llllll}0 & 1 & 2 & 3 & 4 & 5\end{array}$

Where on this scale would you put people who vote rarely?

$\begin{array}{llllll}0 & 1 & 2 & 3 & 4 & 5\end{array}$

3. Where on this scale would you put practicing Christains?

$\begin{array}{llllll}0 & 1 & 2 & 3 & 4 & 5\end{array}$

Where on this scale would you put nonpracticing Christians?

$\begin{array}{llllll}0 & 1 & 2 & 3 & 4 & 5\end{array}$ 


\section{APPENDIX C}

Questionnaire Used in the Interview

Sessions of July 13-14, 1976 
RADIO LISTENER SURVEY

Andrews University

"On-the-Street" Interviews

July 13, 1976
138

THE PURPOSE OF THIS SURVEY:

To study the lifestyles of radio listeners in general.

Therefore, the questions may not necessarily refer to you personally.

We simply want your opinion about certain lifestyles of radio listeners in general.

\section{SAMPLE QUESTION}

Which numbers on this scale do you think best represent people who Iisten to the radio most of the day? ( $0=$ no interest in

radio listening; 5=highest possible interest in radio listening).

\section{ONLY THREE QUESTIONS}

1. Which numbers on this scale do you think best represent sports

fans who like to hear ball games on the radio occasionally, but

who never actually go to a ball game or care much who wins or loses?

$(0=$ no interest in sports at all; $5=$ highest possible interest

in sports).

2. Which numbers on this scale do you think best represent registered 012345 voters who rarely actually show up to vote when the time comes?

$(0=$ no interest in voting at all; $5=$ highest possible interest in voting).

3. Which numbers on this scale do you think best represent christians 012345 who believe in Christianity, but who don't practice what they

believe? ( $0=$ no interest in Christianity; $5=$ highest possible

interest in Christianity).

\section{THANK YOU SO MUCH FOR}

YOUR HELP!

\section{MEASURES CF CENTRAL TENDEYCY KEYED TO ANSUERS TO GUESTION 3}

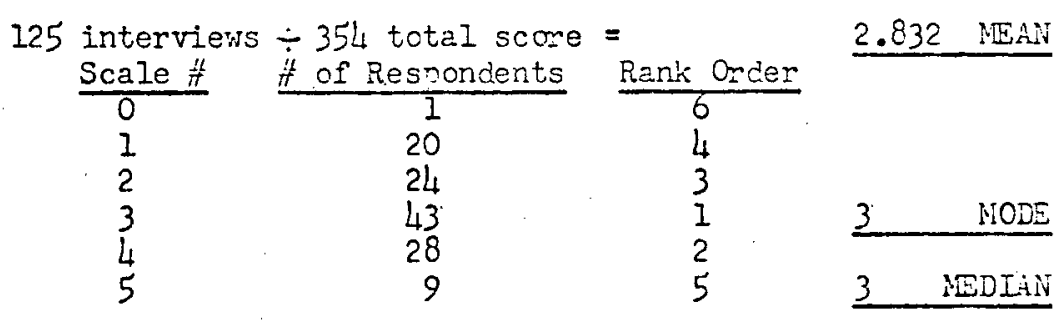

MALE-FEMAIE RATTO and MEANS

$$
\begin{array}{rllll}
\text { Males } & - & 66 & - & 2.848 \text { (MAN) } \\
\text { Females } & - & 59 & -- & 2.813 \text { (NEAN) }
\end{array}
$$

CONCLUSION

Numbers 0123 best represent nominal- to non-Christians 0 means non-Christian

123 means nominal-Christian 
APPENDIX D

Questionnaire Used in the Interview

Session of July 20, 1976 
RADIO LISTENER SURVEY

Andrews University

"On-the-Street" P1lot Interviews

140

$5-m$

July 20, 1976

THE PURPOSE OF THE SURVEY

To study t'he Iife styles and program priferences of radio listeners

in general.

READY?. HERE WE GO!

Plcture in your mind a scale of numbers from 0 to 5 .

0 represents no interest-at-all in doing whatever is being asked about.

5 represents the highest possible interest in doing whatever is being

asked about.

TRY THIS SAMPLE QUESTION

Which number on the scale of 0 to 5 would you honestly pick to 012345 show how much interest you have in personally listening to classical

mustc on the radio? (Remember: $0=$ no interest in personally

listening to classical music on the radio; 5 = always personally

listens to classical music on the radio).

OKAY--HERE ARE THE OUESTIONS QUICKLY!

1. Which number on the scale of 0 to 5 would you honestly pick to (0) 12345 show how much interest you have in personally attending ball games at the stadium? $(0=$ no interest in attending ball games at the stadium; 5 = always attends ball games at the stadium).

2. Which number on the scale of 0 to 5 would you honestly pick to 012345 show how much interest in have in personally wearing seat belts every time you drive? $(0=$ no interest in wearing seat belts; 5 = always wear seat belts).

3. Which number on the scale of 0 to 5 would you honestly pick to (0) 1245 show how much interest you have in personally putting Christian beliefs into practice (such as regular church attendance, prayer, and Bible study). ( $0=$ no interest in personally putting Christian beliefs into practice; 5 = always personally puts Christian beliefs into practice).

RESULTS

THANK YOU VERY IJUCH FOR YOUR HELP

In St: Joseph, 5 out of 15 placed themselves in the nominal- to non-Christian range In Benton Harbor, 6 out of 15 placed themselves in the nominal- to non-Christian

Total: In both St. Joseph and Benton Uarbor (combined totals), 11 out of 30 ranse.

placed themselves in the nominal- to non-Christian range.

CCNCLUSION: 3 times as many people will need to be called to get enough qualified respondents, (i.e. must call 900 to get 300 , the number needed to be statistically significant). 


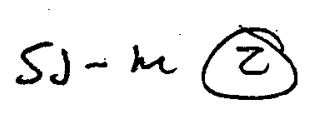

RADIO LISTENER SURVEY

141

Andrews University

"On-the-Street" P1lot Intervlews

July 20, 1976

THE PURPOSE OF THE SURVEY

To study radio program preferences of listeners.

QUESTIONS

1. Generally speaking, which type of radto comnercial would you prefer to hear?

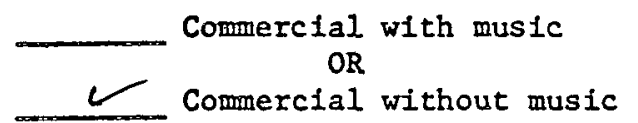

2. Generally speaking, which type of radio commercial do you feel is the most belleveable?

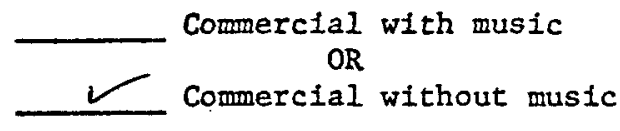

3. Which person on the radio would you be more inclined to belleve?

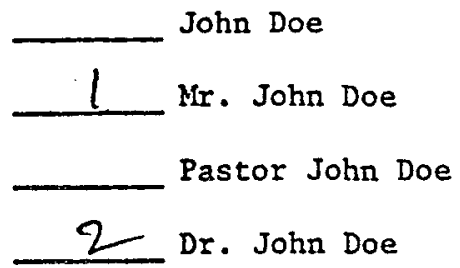

4. Which of the following types of radio comercials do you feel you would enjoy listening to most?

- Announcer reading the-commercial (Announcer Only).
Two people talking to each other In a conversation (Dialo६
"On-the-Street" interviews (Spontaneous Opinions)
Someone telling a personal experience he's had

Who would be your second choice?

(. 
5. Which one of the following types of radio commerclals do you feel is the most believable?

1 Announcer reading the comerctal (Arinouncer Only)
Two people talking to each other in a conversation' (Dialogue)
"On-the-Street" interviews (Spontaneous Opinions)
Someone telling a personal experience he's had

6. If you heard someone on the radio telling about what it's like to be a member of a certain church, who would you be more inclined to believe?

A news reporter
The church pastor
A member of the church

7. Which age category are you in, please?

$$
\begin{aligned}
& \sim_{18-34}^{\text {Below } 18} \\
& \\
& 35-65 \\
& 65 \text { and above }
\end{aligned}
$$

8. What is your race, please?

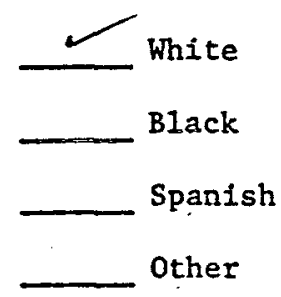


APPENDIX E

Questionnaire Used in the Interview

Session of July 23, 1976 
RADIO LISTENER SURVEY

Andrews University

144

"On-the-Street" Pilot Interviews

July 23, 1976

\section{THE PURPOSE OF THE SURVEY}

To study the life styles and program prefarences of radio listeners.

READY? HERE WE GO!

Plcture in your mind a scale of numbers from 0 to 5.

0 indicates that you have no interest-at-all in doing whatever is being asked about. 5. indicates that you always actually do whatever is being asked about.

\section{QUESTIONS}

1. Which number on the scale of 0 to 5 would you honestly pick to show how much you actually attend ball games at the stadium?

$(0=$ no interest-at-all in attending ball games at the stadium;

$5=$ always actually attend ball games at the stadium).

2. Which number on the scale of 0 to 5 would you honestly pick to show how much you actualiy wear seat belts every time you drive? $(0=$ no interest-at-all in wearing seat belts; $5=$ always actuaily wear seat belts every time you drive).

3. Which number on the scale of 0 to 5 would you honestly pick to show how much you actually put Christian beliefs into practice (such as regular church attendance, prayer, and Bible study)? ( 0 = no interest-at-all in putting Christian beliefs into practice; 5 = always put Christian beliefs into practice).

NOW SOME QUICKIES!

4. What's the first radio commercial that comes to your mind (what was it about?

5. Did you like it? Yes ᄂ No (If "Yes" what did you like about it?) JiNéts

(If "No" what did you dislike

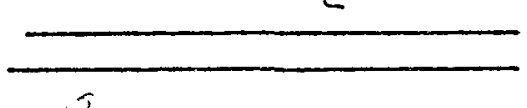

6. Did it wound believable to you? (If "Yes" why?) Beli.f about it?)

No

(If "No" why?) 
7. About how long ago did you hear this commerclal?

Today__ Yesterday

This week

More than a week ago

8. About how many times would you say you've heard it? Mbut 30

9. Generally speaking, which type of radio comerctal would you prefer to hear?

Commercial with music $\longleftarrow$ OR Commercial without music.

10. Generally speaking, which type of radto commercial do you feel is the most believable?

Comercial with music $V$ OR Commercial without music

11. Which person on the radio would you be more inclined to believe?

John Doe __ Mr. John Doe $\longleftarrow$ Pastor John Doe

12. Which type of radio commercial would you enjoy listening to most?

Announcer reading the commercial
Two people talking to each other in a conversation
"On-the-Street" Interviews
_. A personal experience or testimonial being related by someone

13. Which type of radio commercial do you feel is the most believable?

Announcer reading the commercial
"Ono people talking to each other in a conversation
"On-the-Street" interviews
A personal experience or testiwonial being related by someone

14. If you heard someone on the radio telling about what it's like to be a member of a certain church, who would you be more inclined to believe?
A news reporter
A church pastor
A member of the church $L$

15. Wh1ch age category are you in, please?

Below 18

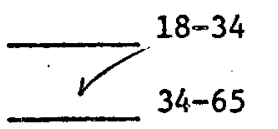

65 and above

16. What is your race, please? White Black Spanish Other 
APPENDIX $\mathrm{F}$

Questionnaire Used in the Interview

Session of September 2, 1976 
RADIO SPOTS SURVEY-1

Andrews Unfversity

Seprember 2, 1976
147

SUMMARY OF RESULTS

IN TOTALS AND RANK ORDER

SU and BH COMBINED

Generally, which of the following four expes of radio comnerctals Eppeals to you most?
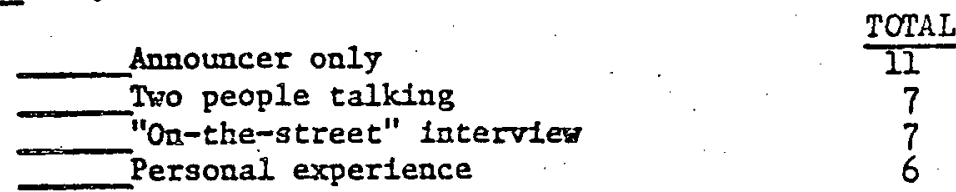

RANK ORDER Two people talking "On-the-street" fnter

11
7
7
6

2

2

3

Generally which of those types of comercials do you feel is the most bellevable?

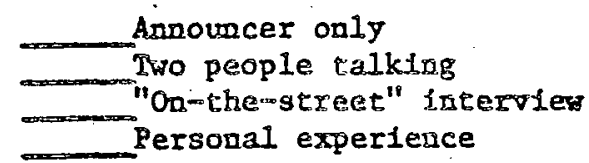

RADIO SPOTS SURVEY--2

Andrews University

September 2, 1976

Generally, which of the following four types of radio commercials appeals to you most?

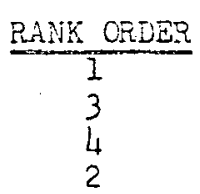

Generally, which of the following four types of radlo commerclais do you feel is the most bellevable?

Annowncer reading the commercial

Announcer reading the commerwal

Two people talking in a conversation

"On-the-street" Interviews

$\frac{\text { TCTAL }}{13}$

Personal experiences rold by someone

10

Two people talking in a conversation

"On-the-street" interviews

\begin{tabular}{r} 
TCTAL \\
\hline 5 \\
3 \\
8 \\
14
\end{tabular}

RAIX CRDER

Personal experiences told by someone

14

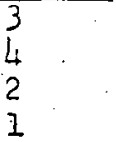


APPENDIX G

Term Definitions Form Used in the Interview

Session of September 13, 1976 
September 13, 1976

RADIO SPOT OT Tulk alut subjint - 5-10:4ir.

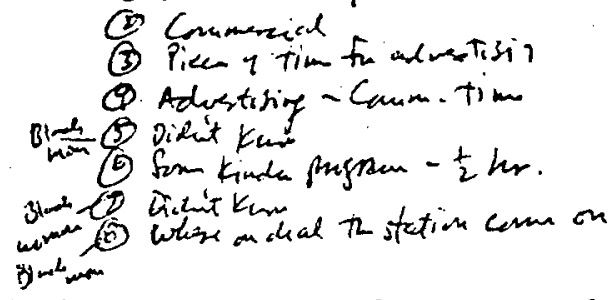

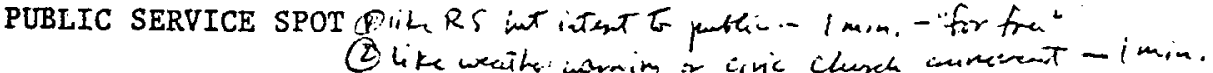

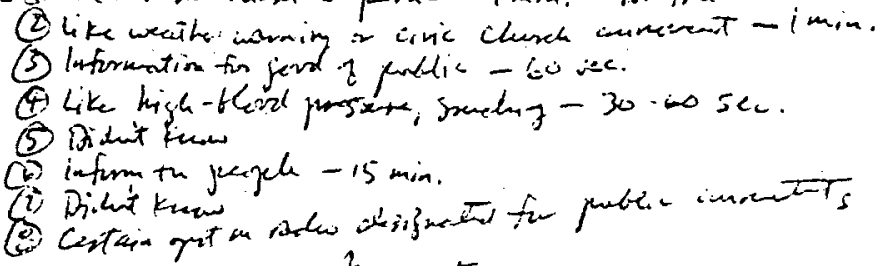

PUBLIC SERVICE MESSAGE (1) ikesion leyger the ipet

(5) Sum iscion iss

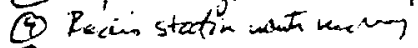

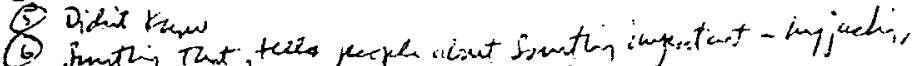

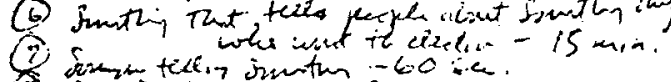

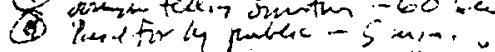

SHORT PUBLIC SERVICE MESSAGE $O$ Note i it tret - irest, enat

(2) Annorint of Fron chat.

(3) Omen Seaticuses

(2) Samin - $30.60 \mathrm{se}$

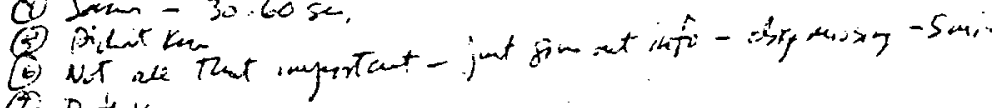

(i) Dint ken, min.

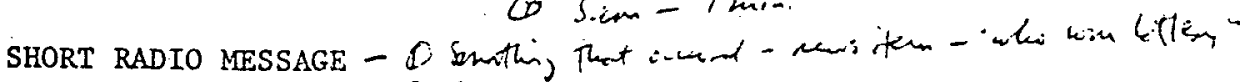

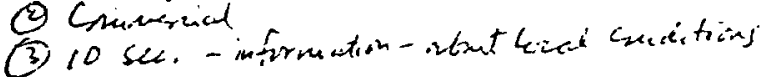

(t) Didir kmom

(5) Dilut in

(i) Can lates

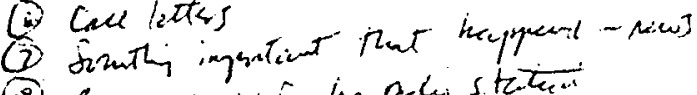

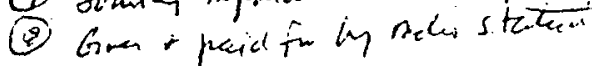

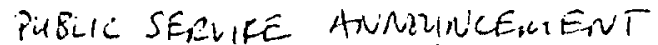

in.

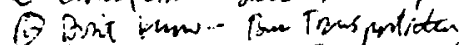

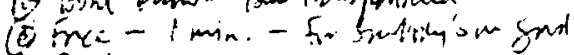

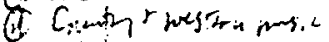

tisnilim

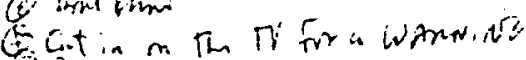

it int isur

(5) pine;

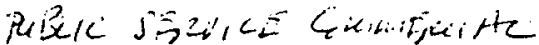

(i) Binik.

(i) Sume $\approx$ seon

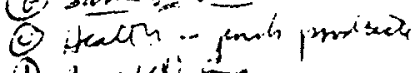

ic inupuesis itr

C. Ant ins

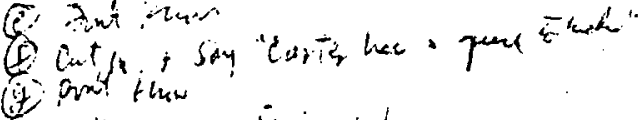

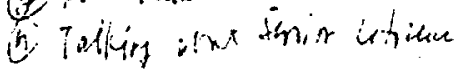




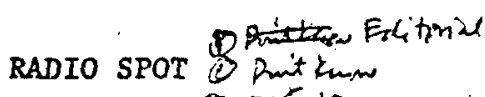

(1) Dर्य kim

Q. Ant know coverge

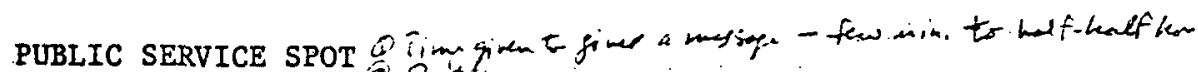

$$
\begin{aligned}
& 3 \text { Dutknow } \\
& \text { CS Give what's ging on in cromunit, } \\
& \text { of tre corlostiont } \\
& \text { (5) Dnit knw }
\end{aligned}
$$

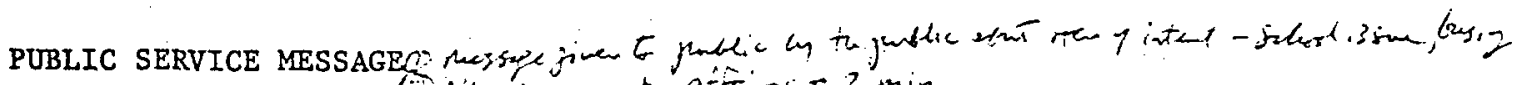

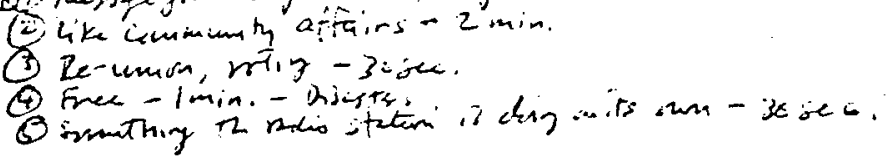

SHORT PUBLIC SERVICE MESSAGEC Lik p>i- 2 maj- 2 mia.

$$
\begin{aligned}
& \text { (c) Seme - } 12 \text { main } \\
& \text { (3) Sirn } \\
& \text { Q } 15 \text { min. }
\end{aligned}
$$

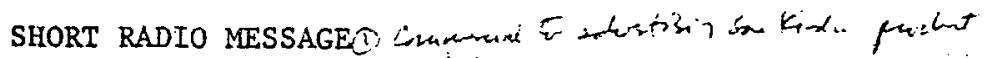

(2) Dnit kum

(3) Atustistant

(4) $15 \mathrm{sec}$ - adertisut 7 akis station' itseit

(5) Bundectin-insis

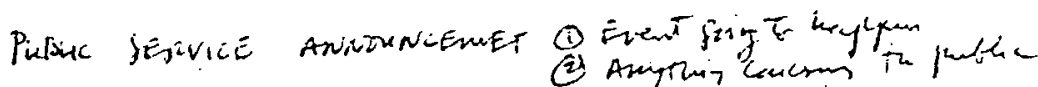

$$
\begin{aligned}
& \text { (2) Arugring cancrms in pube } \\
& \text { (4) Bant know } \\
& \text { (5) bisuring } 1 \text { bed weattur }
\end{aligned}
$$

STROT RARIO PRESENIAT WenS

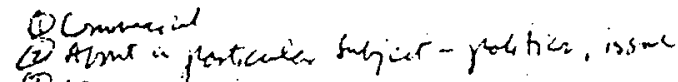

(O) is men, in tion

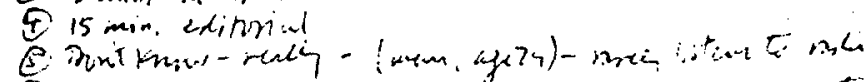

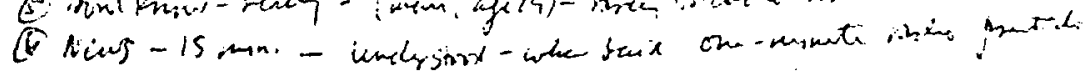

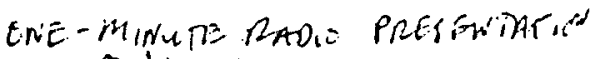

Cituting

EAruction - hir

(i) immerai..i - ir arietion

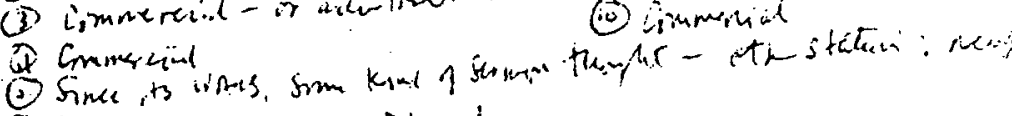

(i) Pititivat or mon-mint an

(1) Elothl vins 


\section{APPENDIX H}

The Names and Positions of Twenty-one Faculty

Members Who Were Sent Copies: of A

Preliminary Survey Instrument 


\section{FACULTY CONSULTATION}

Below are the names and positions of twenty-one Andrews University faculty members who were sent copies of a preliminary draft of the survey instrument. An asterisk (*) has been placed beside the names of those who responded to this request for assistance.

*George Akers, Ed.D., Professor of Religicus Education *David Bauer, M.A., Vice President for Development and Relations

*LeRoy Botten, M.S., Director, Computing Center

*Elden Chalmers, Ph.D., Professor of Pastoral Care and Nurture

Carl Coffman, M.Div., Professor of Religion

*Robert Cruise, Ph.D., Associate Professor of Measurement and Evaluation

*Wilfred Futcher, Ph.D., Professor of Measurement and Evaluation

*William Garber, M.A., Assistant Professor of Journalism

*Elaine Giddings, Ph.D., Professor of Communication

*Donald Jacobsen, D.Min., Professor of Evangelism and Pastoral. Nurture

Rudolf Klimes, Ph.D., Professor of Educational Administration

*Arnold Kurtz, D.Min., Ph.D., Professor of Church Leadership and Administration

*C. Mervyn Maxwe11, Ph.D., Professor of Church History

*Raymond Moore, Ph.D., Director, Hewitt Research Center

*Harold Phillips, Ph.D., Professor of Business Administration

Benjamin Reaves, D.Min., Associate Professor of Preaching and Urban Ministry

Kenneth Strand, Ph.D., Professor of Church History

*Louis Venden, B.D., Associate Professor of Preaching

*Steven Vitrano, Ph.D., Professor of Preaching

Robert Williams, Ph.D., Professor of Counselor Education

*Wayne Woodhans, B.A., Station Manager, WAUS-FM

Copies of the two following pages were sent to all of the

above persons for their comments and evaluations. 
APPENDIX I

The Form Letter and Preliminary Survey Instrument

Sent to Twenty-one Andrews University

Faculty Members 
Andrews University Berrien Springs, Michigan 49104 (616) 471-7771

August 11, 1976

This is another form letter.

But 1t's being sent to you personally.... and for a very special reason! I need your particular expertise to help me in the final drafting of the survey instrument for my dissertation.

Could you take 5 minutes or so to look it over and write me a few comments and suggestions, please? I'd surely appreciate it:

The survey will be taken by phone, using the Benton Harbor-St. Joseph phone book (white pages only). The objective of the study is to discover which of the most comonly used radio production formats contribute most to credibility and acceptability of religious radio spots whose intended audience is either nominallyor non-Christian, and to produce a thirteen week series of daily public service radio spots for evangelistic purposes based on this letermination.

You'11 notice on the first page that the method of determining who are nominal- and non-Christians has been formulated. This is the result of nearly 300 informal "on-the-street" interviews in both Benton Harbor and St. Joseph. Two of the three measures of central tendency (median and mode) pointed to 3 and below (on the scale) as being the area of nominal-to non-Christians. The mean was 2.83 .

Again, thank you so much for your comments and suggestions, And if you have ideas for additional questions, I'd be very happy to receive those as well!

Sincerely yours,

James D. Chase

Communication Department 


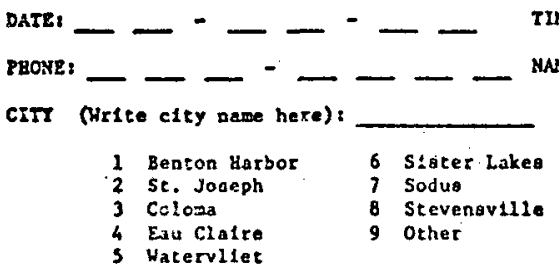

IMTRODUCTION: He110. I'm f rom Andrewe jifiverafty. he're dolng a brlef radio survey this eventng. And I need your help with a few questions on radio 11steners" If eatyles and preferences, okay? (It'11 only take a few minutes and $I$ ' 11 be very grateful). (Supervisor phone no.:

Plcture Iu your wind a scale of numbers from zero to five. zero indicaten that you have no interest-at-all is dolng whatever is being asked about. Five indlcatea thet you do $1 t$ all the time, okay?

2. thich numbex on the scale of 0 to $s$ would you honesty plck to show how much you actually attend baseball games at the atadium? (0) no interest-at-all in attending basabail gases at the stadium; 5 - always atcendo baseball ganes ot the otadiur).

3. Which nuober on the scale of 0 to 5 would you honestly plck to show how much you actully. wear sat belta every tioe you drive? ( 0 - no interest-at-all in wearing seat beles; 5 - elwayo weat seat belto every tre you drive).

3. Which number on the scale of 0 to 5 sould you honestiy plck to show how much you actually put Christian bellef. 1ato practice, ouch as regular church attendunce, prayar. ond bible study? (0 - no interest-at-all in putting Christian bellefo into practica; 5 - alwaya puto Chriatian bellefa into practice). 
RELIGIOUS RADIO SPOTS SURVEY, PAgE 2

5. Generally opeaklng whlch type of radlo comorelal do you teal

1o the most bellevable... If you had to make choles?

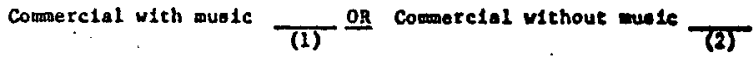

6. Generally apeaking, which radlo epeaker would you be sore

Inclined to $11 \mathrm{gten}$ to....1t you had to make a cholce?

$$
\begin{aligned}
& \text { John Doe } \\
& \text { (1) } \\
& \text { Pastor John Doe }
\end{aligned}
$$

7. Cenerally opeaklng, whlch radio epeaker alght oound the eost bellevable to you on-the-8urfaco... If you hed to wake cholcel

John Doe

Pator John Doa

8. Now, here are four different types of radio comerciale. Ubich Mr. John Doe typo would you enfoy 11 atening to most?
(1)
(2) Announcer reading the comerclal
To people tolking in copverearton
(3) — Personal opinion Incerviews "on-tha-ecreet"
(4) - Peroinal experfences told by someone

9. Which of those types of comerclale do you feel 1 the soet belleveblet
(1)
(2)
(3)
(4)
Anouncer reading the comerclet
Two people talking in a converbation Peroonal opinion intervieus "on-the-ezgets"

10. If you heard someone on the radio telling about wat $1 c^{\circ}$. 11 ke to be a Christian, who would you be wore lacilned to belleyat

A comentator

$$
\text { (1) }
$$

1 pascor

11. Which aga category are you in, pleseet

A church mesuber $\boldsymbol{7}$

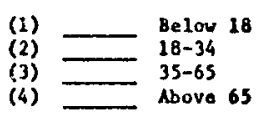

12. What to yout race, pleaset

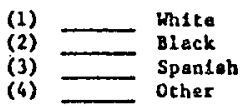

13. Sext

Male 
APPENDIX J

A Copy of the Telephone Survey Instrument

Used in This Project 
Do not write in this oreo

USING A \#2 PENCIL, BLACKEN THE BOX WHICH CORRESPONDS TO YOUR ANSWER. SAMPIO
RELIGIUUS RADIO SPOTS SURVEY. . JAMES D. CMASE...FALL, 1976.

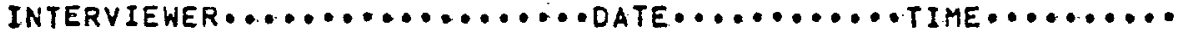

PERSON CALLED............PHENE NUMBER $\ldots \ldots \ldots \ldots \ldots \ldots \ldots \ldots$

CITY.......... BENTON HARBOR...... ST. JUSEPH.........

INTRODUCTION.....HELLO. I AM.........FROM ANUREWS UNIVERSITY. WE ARE DOING A BRIEF RADIO SURVEY TEDAY. AND I NEED YUUR HELP WITH A FEW QUESTIONS ON RADIO LISTENER FREFERENCES, TU. HELP US IMPROVE OUR BROADCASTS, OKAY. IT WILL ONLY TAKE A

FEW MINUTES AND I WILL BE VERY GRATEFUL.

PICTURE IN YUUR MINO A RON GF NUMBERS FROM ZERO TU FIVE.

0.0

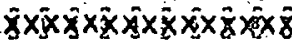

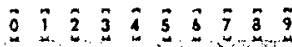

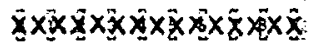

$\bar{x} \times \bar{x} \bar{x} \times \bar{x} \bar{x} \times \bar{x} \times \bar{x} \times \bar{x} \times \bar{x} \times \bar{x}$ AND LET US CALL THAT ROW OF NUMBERS A SCALE, OKAY. ZERO MEANS

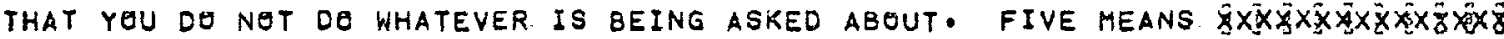
THAT YUU DO IT ALL THE TIME. DO YOU UNDERSTANU?

1. WHICH NUMBER ON THE SCALE OF O TO 5 WEULO YOU HONESTLY PICK TO SHOW HOW MUCH YUU ACTUALLY ATTENO SPURTING EVENTS. - MEANS YUU DO NOT ATTEND SPGRTING EVENTS. 5 MEANS YQL ATTEND SPORTING EVENTS AS OFTEN. AS POSSIBLE.

2. WHICH NUMBER ON THE SCALE OF O TO 5 WUULD YOU HONESTLY PICK TO. SHOW HOW MUCH YEU ACTUALLY WEAR SEAT BELTS EVERY TIME YOU DRIVE. O MEANS YOU NEVER WEAR SEAT BELTS. 5 MEANS YEU ALWAYS WEAR SEAT BELTS.

3. WHICH NUMBER EN THE SCALE EF O TO 5 WUULD YOU HONESTLY PICK TO SHOW HOW MUCH YOU ACTUALLY PUT CHRISTIAN BELIEFS INTE PHACTICE, SUCH AS REGULAF CHUKCH ATTENDANCE, PRAYER, AND STUDY OF THE SCRIPTURES. O MEANS THAT YOU DO NOT PLT CHRISTIAN BELIEFS INTO HRACTICE. 5 MEANS THAT YOU ALWAYS PUT CHRISTIAN BELIEFS INTO PRACTICE. .... NUTE... If 3 OR BELUw, CUNTINUE INTEKVIEW...... ....BUT, IF 4 GR 5 , THANK PERSEN AND HANG UP......

NEK, BESIOES COMMERCIALS, RADIO STATIENS PLAY UNE MINUTE PFESENTATIONS FREM NON PREFIT ERGANIZATIONS. THE LAST FEW GUESTIONS DEAL WITH THIS KIND OF ONE MINUTE PRESENTATION. SINCE EACH QUESTION IS MULTIPLE CHOICE, YEU SIMPLY TELL ME WHICH ANSWER YOU PREFER.

$\dot{x} \times \bar{x} \bar{x} \times \ddot{x} \times \dot{x} \times \bar{x} \bar{x} \times \bar{x} \times \dot{x} \times \ddot{x}$

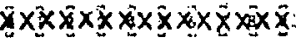

$x \times \times \times \times \times \times \times \times \times \times x \times x$

$\bar{x} \times \bar{x} \times \bar{x} \times \bar{x} \times \bar{x} \times \bar{x} \times \bar{x} \times \bar{x} \times \bar{x}$

$x \times \times \times \times \times \times \times \times \times \times \times \times \times x$

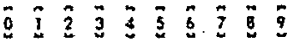

$x \times \times \times \times \times x \times x \times x \times x \times x$

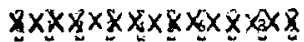

4. GeNERALLY, ARE YOU MORE INCLINED TO LISTEN TU a ONE MINUTE RADIO PRESENTATIUN...

1 WITH MUSIC...OR...

2 WITHOUT MUSIC

3 IT MAKES NO DIFFERENCE

5. GENERALLY, WHICH TYPE OF ONE MINUTE RADIE HRESENTATION SEUNDS THE MOST BELIEVABLE TO YUU...

1 WITH MUSIC...OR...

2 WITHOUT MUSIC

3 IT MAKES NO DIFFERENCE

$x \times \times \times \times x \times \times \times x \times x \times x \times$

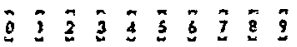

$x \times x \times x \times x \times x \times x \times x \times x$

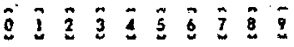

$\bar{x} \times x \times x \times x \times \dot{x} \times \dot{x} \times \dot{x} \times x \times$

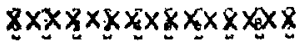

USE A \#2 PENCIL - ERASE COMPLETELY WHEN MAKING CORRECTIONS 
Do not write
in this orea

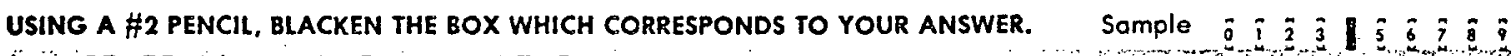

6. GENERALLY, WHICH ONE OF THE FOLLEWING TYPES OF ONE

MINUTE RADIO PRESENTATIONS ARE YOU MOST INCLINED. TO

LISTEN TO ...

1 ANNUUNCER READING THE SCRIṔT

TWO PEOPLE TALKING TO EACH OTHER

ON THE STREET. INTERVIEWS

SOMEONE TELLING A PERSUNAL EXPERIENCE HE: HAS HAD

IT MAKES NO DIFFERENCE

7. GENERALLY, WHICH ONE OF THOSE TYPES OF ONE MINUTE

RADIU PRESENTATIONS SUUNDS THE MOST BELIEVAZLE TO YOU...

1 ANNOUNCER READING THE SCRIPT

2. TWO PEOPLE TALKING TO EACH OTHER

3 ON THE STREET INTERVIEWS

4. SUMEUNe telling a personal eXPERIENCE he has. had

5 IT MAKES NO OIFFERENCE

8. GeNERALLy, WHICH oNe OF THE FOLLOWING TYPES OF ONE MINUTE RADIO PRESENTATIONS MIGHT YOU BE MOST INCLINED

TO LISTEN TO ...

1 A COMMENTATER DISCUSSING CHRISTIANITY

2 A PASTOR EXPLAINING CHRISTIANITY...ER ...

3 ANY CHRISTIAN TELLING WHY HE IS ENE

4 IT MAKES. NO DIFFERENCE

9. GENERALLY, WHICH OF THESE TYPES GF ONE MINUTE RADIO

PRESENTATIENS SOUNDS THE MUST BELIEVABLE TO YOU...

1 A COMMENTATOR DISCUSSING CHRISTIANITY

2 A PASTOR EXPLAINING CHRISTIANITY...UR...

3 ANY CHRISTIAN TELLING WHY HE IS ONE

4 IT MAKES NO DIFFERENCE

1C. COULD YOU TELL ME WHICH UF THE FOLLUWING alie categeries YOU ARE IN, PLEASE...

1 BELOW 18

$\begin{array}{lllll}2 & 18 & \text { TO } & 34\end{array}$

$3 \quad 35$ TO 65

4 ABUVE 65

11. COULD YOU TELL ME WHICH OF THE FOLLONING RACES YOU REPRESENT, PLEASE...

1 WHITE

2 BLACK

3 SPANISH

12. SEX...

4 OTHER

1 MALE

2 FEMALE

A THANK YOU VERY MUCH FOR YOUR MELP. GUOD BYE.

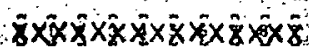

$\bar{x} \times \bar{x} \bar{x} \times \bar{x} \times \bar{x} x \bar{x} \times \bar{x} \times \bar{x} \times \bar{x} x \bar{x}$

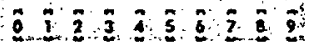

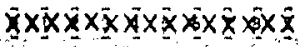

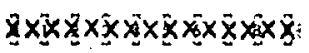

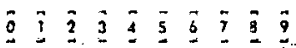

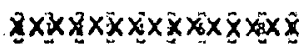

$\bar{x} \times \bar{x} \times x \times x \times x \times x \times x \times x x$

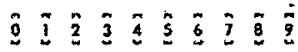

$x \times x x x x x \times x x i x x i x$

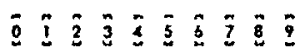
$\cdots$

$\underline{x} \times x \times x \times x \times x \times x \times x \times x x$

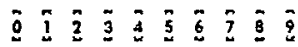

$x \times x \times x \times x \times x \times x \times x \times x \times$

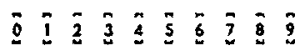

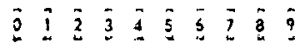

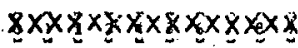

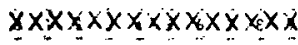

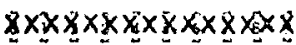

USE A \#2 PENCIL - ERASE COMPLETELY WHEN MAKING CORRECTIONS FORM NO. i 1000. 
APPENDIX K

Scripts for the Thirteen-week Series of Daily Radio Spots Produced as a Part of This Project 
TURNING POINT

Week 1

Spot 1

Theme music up then under and out

CHASE :

Turning Point . . sixty seconds of contrast.

INTERVIEWEE: I was listening to a song by a man who was singing. "My Sweet Lord." And it seemed to me like he was crying out for God. He wanted to know God, and to see Him. And that was the day I was feeling. And as I concentrated more on that,. I just began to feel the actual presence of God. And I found myself on my knees, crying. And pleading with God to make Himself real. I . . I couldn't take this plastic religion, this just once a week. . . it had to be a way of life. It had to be the real thing. I have - . I have experienced that. Not totally . . but I'm growing in that.

Theme music up then under CHASE : Turning Point . . worth a second thought. . from the Seventh-day Adventist Church.

Theme music up then out 
TURNING POINT

Week 1

Spot 2

Theme music up then under and out

CHASE :

Turning Point . . . sixty seconds of contrast.

INTERVIEWEE: You know, it was like every two months someone was dying from an overdose of drugs. And, you know, I knew this wasn't the right way. I knew that all that I was doing was wrong, from what my parents had told me. But yet, no one had an answer for me. And ... to see someone die ... and to wonder, What's life about? What's it for? What am I here for? And to not come up with an answer... you're very alone. And there are so many people in this world that are so alone. We're reaching out. But we don't have anything definite to grasp onto. And... God is definite. He says in His Word, I will give you what you need. And that's God to me.

Theme muic up then under

CHASE : Turning Point. . . worth a second thought... from the Seventh-day Adventist Church.

Theme music up then out 
TURNING POINT

Week 1

Spot 3

Theme music up then under and out

CHASE:

Turning Point . . sixty seconds of contrast.

INTERVIEWEE: I used to be a jazz musician. I would travel

about, and go to Chicago and play in different

bands. I also played in rock bands here and there.

And, of course, being in this kind of environment

brought me into a lot of loose living, so to speak

-. ah, drugs, sex, liquor--the whole bit. And

after awhile, my life had gotten to the point where

I would do these things just to get high . . . or,

or get involved in these things just to forget

about all my troubles. Yet, when the next day

came, I found a big vacuum, inside. I felt empty.

And I knew that these things were only satisfying

for must the moment.

Theme music up then under

CHASE: Turning Point . . worth a second thought . .

from the Seventh-day Adventist Church.

Theme music up then out 
TURNING POINT

Week 1

Spot 4

Theme music up then under and out

CHASE :

Turning Point . . sixty seconds of contrast.

INTERVIEWEE: My sister called me up on the phone and told me

that she was going in for tests for cancer. I

couldn't understand why these things have to happen.

But He supplied me the comfort of accepting that

this is life. . these things happen. But . . I

will take care of you. I will love you. I will

care for you. And when I got off the phone, I

prayed, God, help me. My sister's not a Christian

- . and I love her. And I don't want anything to

happen to her. Be with her. Impress upon her that

You love her and You care for her. I can't do any-

thing. But you can.

Theme music up then under

CHASE: Turning Point . . worth a second thought...

from the Seventh-day Adventist Church.

Theme music up then out 
TURNING POINT

Week 1

Spot 5

Theme music up then under and out

CHASE :

Turning Point . . sixty seconds of contrast.

INTERVIEWEE: I just felt such a hungering inside of myself to,

to know for sure who I was. And to be, to be,

ah, found, so to speak. And ah, I attended meet-

ings. I wasn't satisfied with what I found. I

did meet a man who was a dentist. He spent a lot

of time talking with me before he ever looked at

my teeth. More than a half an hour. I thought

that was unusua1. Why would he be so interested

in me? He told me he had had a religious experi-

ence. . and did I want to play tennis with him.

And did I want to get to meet his wife, who had

also had a religious experience. And maybe we

could share some things together. . W Wot to

know them. They loved us very much. And I found

that there are people in the world who do really

have a living connection with God. And it. .

knowing them helped to change my life.

Theme music up then under

CHASE : Turning Point... worth a second thought . .

from the Seventh-day Adventist Church.

Theme music up then out 
TURNING POINT

Week 2

Spot 1

Theme music up then under and out

CHASE : Turning Point . sixty seconds of contrast.

INTERVIEWEE: Wel1, all my life I . . I guess I was religious, to a certain extent. I believed in God. I always prayed . . not all the time. But for the most part, I did pray. And ah, I had some kind of a church background, but as soon as I reached highschool level, I quit going to church. And yet, I still believed in God. I had nice cars. I had plenty of girlfriends, and all this type of thing. I realized that emptiness inside of me. And would pray at night. I'd say, Lord, if You're really there, please take me from this kind of life. There's got to be something more to 1ife. There's got to be a purpose for me on this earth.

Theme nusic up then under

CHASE : Turning Point... worth a second thought ... from the Seventh-day Adventist Church.

Theme music up then out 
TURNING POINT

Week 2

Spot 3

Theme music up then under and out

CHASE : Turning Point . . sixty seconds of contrast.

INTERVIEWEE: And my sister told me that she felt assured that I was on her side. That whatever happened. . it would be okay, because I would be there. To me, she was saying that, I know, Carol, that you'11 pray for me. I know that God'11 take care of it, because you believe it. Maybe I don't. But you do. And when I see things like this happening . . you know, that, I'm not strong enough to take, I'm not strong enough to handle--but yet, God can take care of it. . that shows to me He's real... He's so real.

Theme music up then under

CHASE : Turning Point. . . worth a second thought. . from the Seventh-day Adventist Church.

Theme music up then out 
TURNING POINT

Week 2

Spot 4

Theme music up then under and out

CHASE :

Turning Point . . sixty seconds of contrast.

INTERVIEWEE: Having come to know God in a real way, a way that

I can see that it's all right if I make a mistake.

He's going to love me anyway. That gives me incen-

tive to reach out and take risks. By taking these

risks, I've been successful. And the success gives

me a degree of confidence. So that now I have more confidence to communicate with my father. And one

of the most exciting things about being a Christian,

is that I have love in my heart--geniune love for

my father. And I know God has put that there. I

wasn't capable of generating that before. It was

- . it was hatred, and it was, You-don't-like me--

I don't-like-you . . . based upon a misunderstand-

ing. And, if you will, God has opened my eyes.

It's the dawning of a new day.

Theme music up then under

CHASE : Turning Point . . worth a second thought...

from the Seventh-day Adventist Church.

Theme music up then out 
TURNING POINT

Week 2

Spot 5

Theme music up then under and out

CHASE : Turning Point ... sixty seconds of contrast.

INTERVIEWEE: ' I come from a family with nine children. I'm in the middle. And when you have nine children, and bills, and responsibilities. . you don't have much time for each one of them individually. And with me being in the middle, and with my mother having complications with my next sister, there wasn't a lot of time. for me. And I had older brothers and a sister that . . they always played together. They always did things together. But, I was a baby for five years. And . . no one had time for me. No one, you know, really cared about what I was doing, and what I was feeling.

Theme music up then under CHASE : Turning Point . . worth a second thought . . from the Seventh-day Adventist Church.

Theme music up then out 
TURNING POINT

Week 3

Spot 1

Theme music up then under and out

CHASE :

Turning Point . . sixty seconds of contrast.

INTERVIEWEE: My Dad asked me one time, How do you know that

Christ is coming soon? (I had mentioned that to

him). And I turned to the book of Malachi, the

last two verses, where it says that God would turn

the hearts of the fathers to the children, and the children to the father's. And I said to him, Dad,

I believe that we're seeing fulfillment of this prophecy in our day. And, this to me is one of the greatest evidences that God is soon to restore the world the way He meant it to be in the beginning. And, the greatest evidence is what's going on in the hearts of people. I know from my own experience, the change in my own heart . . If anybody asked me, How do you know there is a God, it's just that I know He's created in me a new heart. He's given me a new capacity to love... a whole new person.

Theme music up then under

CHASE : Turning Point . . worth a second thought... from the Seventh-day Adventist Chruch.

Theme music up then out. 
TURNING POINT

Week 3

Spot 2

Theme music up then under and out

CHASE : Turning Point... sixty seconds of contrast.

INTERVIEWEE: I never realized how bad I was. I thought I had the thing in control. When anyone tells me that marijuana, or pot, doesn't get you hooked on something else... they're just full of boloney. They don't know what they're talking about. I know from experience that it does. I had the same idea. I thought I was in control. But I found out later that I was not in control. Someone asked me, How long has it been since you were straight? And I began thinking, Well, it's been about a month. No, it's maybe two months. No . . and then, ah, I was reminded that it was well over a year. And I realized that was true. And then I began to think, well, hey, maybe I do have a problem. And it wasn't just pot. It had become LSD, and hash, and youname-it.

Theme music up then under CHASE : Turning Point. . worth a second thought... from the Seventh-day Adventist Church.

Theme music up then out 
TURNING POINT

Week 3

Spot 3

Theme music up then under and out

CHASE :

Turning Point . . sixty seconds of contrast.

INTERVIEWEE: I was in a car accident. And then, ah, the man came out of the car. And I was just standing there...

I was so afraid. And he said, Are you okay, Miss?

And I said, We11, I guess so. But what really

happened? (Because it happened so fast). And he

said, Well, we were in an accident. You were over

in my lane. And I said, Oh ... I'm, I'm sorry.

And he said, You know, if there would have been

three more inches, it would have been your life.

And I looked at him, and I thought, It would have

been my life. . what's my life for? What's the

purpose behind my life anyway?

Your know, three inches... and it's your life.

Theme music up then under

CHASE : Turning Point . . worth a second thought...

from the Seventh-day Adventist Church.

Theme music up then out 
TURNING POINT

Week 3

Spot 4

Theme music up then under and out

CHASE :

Turning Point . . sixty seconds of contrast.

INTERVIEWEE: I was just kinda driving down the road, and not really thinking of what I was doing . . just kept going. I had to get on to work, you know, and next thing I knew, I looked up--and there was a car - . right into me, you know. There's the car . . and I. . CRASH, you know. And I thought, Oh no. You know, what happened here? And then I pulled off on the side of the road. And I stopped, and I thought, Ohhhhhh. And I thought, Thank God neither one of us are hurt.. . but Who's God? How can I thank God when I don't really even know Him? And, I don't know, now that I look at it... I can see how God worked. You know, in sparing my life for a purpose.

CHASE: What do you think that purpose was?

INTERVIEWEE: We11, for me to accept Him, and to learn to love Him.

Theme music up then under CHASE : Turning Point . . worth a second thought . . from the Seventh-day Adventist Church.

Theme music up then out 
TURNING POINT

Week 3

Spot 5

Theme music up then under and out

CHASE :

Turning Point . . sixty seconds of contrast.

INTERVIEWEE: This emptiness, this void was filled when I began to realize that indeed there was a God.. . Who

was a person. Not abstract. This was the idea

I had in my mind, that He was abstract. I needed that personality. . of God... so that I could relate to Him. And when I began to find that, I began to feel this void in my life being filled. And as I began to study the Bible, I began to find out that He had some specific plans for my life. And in fact, He had a tremendous plan for my life - . which was higher than I could ever imagine.

Theme music up then under

CHASE: Turning Point . . worth a second thought ... from the Seventh-day Adventist Church.

Theme music up then out 
TURNING POINT

Week 4

Spot 1

Theme music up then under and out

CHASE :

Turning Point. . sixty seconds of contrast.

INTERVIEWEE: I had always thought of God being kind of a nebulous type of thing... energy, matter. But I had never thought that Christ was partaking in Creation, and that He was the Son of God, the same Person that came in human flesh, to this earth.

CHASE : What did that do to you. . . when you found that out?

INTERVIEWEE: We1l, it drew me. There was something that had power in it. And it enticed me through the message and through knowing that I could be like Christ. Because He suffered the kind of life that we live on this earth. He has gone through the same type of things. And so at that point in my life, I realized that I need Christ, I needed Jesus.

Theme music up then under CHASE : Turning Point . . worth a second thought ... from the Seventh-day Adventist Church.

Theme music up then out 
TURNING POINT

Week 4

Spot 2

Theme music up then under and out

CHASE :

Turning Point.. . sixty seconds of contrast.

INTERVIEWEE: While I was in the theater, I might add, my father passed away. And this was another great shock to my life.. . of the realities, and the shortness of how life is. $\therefore$ that it's very transitory. So this caused me again to, to ah, re-evaluate my position. I felt an inner calling to take a second look at my Christian upbringing . . whether this might be something that would Iiberate me from the anxiety that I was going through at that particular time. So . . I decided to read the Bible. And I was convicted that what the world needed was Christianity.

Theme music up then under

CHASE: Turning Point . . worth a second thought . . from the Seventh-day Adventist Church.

Theme music up then out 
TURNING POINT

Week 4

Spot 3

Theme music up then under and out

CHASE :

Turning Point. . sixty seconds of contrast.

INTERVIEWEE: My situations that I was going through right there, the experiences.. . the verses seemed to just

jump out at me, and put my experience into perspec-

tive. And show me a direction to follow. And I was

extremely impressed with reading the Bible . .

that this was a living book. It wasn't in archaic

language that nobody could understand. These were

living people. They had experiences similar to

mine, and I identified with the people, and what

they had gone through. And the great struggles

and the great victories that they had overcome.

I found it a fascinating Book. I still do, and I'd

recommend that to anyone.

Theme music up then under

CHASE :

Turning Point. . worth a second thought. .

from the Seventh-day Adventist Church.

Theme music up then out 
TURNING POINT

Week 4

Spot 4

Theme music up then under and out

CHASE :

Turning Point. . sixty seconds of contrast.

INTERVIEWEE: I . . I know for sure... that He has given me sufficient evidence to base my faith upon. It's not on sand. He's demonstrated how He's taken care of us. He's taken care of us when we had no money, when we made decisions to follow Him . . He provided for our needs.. . in miraculous ways. This is how faith becomes a real thing. It's not pie-inthe-sky . . which is what I thought faith was. It was a stupid word to me. It was a word that was used when you didn't know the answer. And that's the way I thought people used God, too. I used to feel sorry for them. But now, I feel sorry for people who don't know God ... . because I've been on both sides of the fence.

Theme music up then udner

CHASE : Turning Point. . worth a second thought... from the Seventh-day Adventist Church.

Theme music up then out 
TURNING POINT

Week 4

Spot 5

Theme music up then under and out

CHASE :

Turning Point . . sixty seconds of contrast.

INTERVIEWEE: I started to just relax and to fall asleep.

And just before I did, there was a tremendous

explosion. . that took place. And I started

travelling through the ceiling and out into the

cosmos. And ah, stars were going past me like

crazy. And I was just traveling at a some phenom-

enal rate of speed. And it scared me . . so

much . . that I said, Oh God, help me. Take me

back, you know. And immediately, I was brought

back. My body was ice cold. It was clammy,

sweaty. And I woke up my roommate, and I'said, Bob,

I don't know what's happened to me, but ... . you

wouldn't believe what happened to me. I said, I

traveled through space. And he said, Don't fool

around with that stuff. He says, That's from the

devil.

Theme music up then under

CHASE: Turning Point . . worth a second thought . .

from the Seventh-day Adventist Church.

Theme music up then out 
TURNING POINT

Week 5

Spot 1

Theme music up then under and out

CHASE :

Turning Point . . sixty seconds of contrast.

INTERVIEWEE: You know, my Mom's a beautiful woman. You know,

she has just a heart of gold. But she was so busy

and wrapped up with . . getting the house

cleaned, and preparing meals, and making sure

things were ready for when Dad got home, and cuts

and bruises that my brothers and sisters had...

that I was really kind of isolated. You know, I

didn't have a puppy to play with. . . or a

bicycle of my own to ride. And. . . I really

felt like I was sheltered. . . so I did rebel.

Theme music up then under

CHASE :

Turning Point . . worth a second thought . •

from the Seventh-day Adventist Church.

Theme music up then out 
TURNING POINT

Week 5

Spot 2

Theme music up then under and out

CHASE :

Turning Point. . . sixty seconds of contrast.

INTERVIEWEE: You know, my Dad was next to being an alcoholic.

And . . I couldn't relate to him. He ummm . .

he paid our bills. . he made sure we had food on

the table. . he made sure we had clothes to wear.

And that we got to school. But he didn't have time

to . . to really be a father, at what I would

think a father would be. . . have time to love us,

have time to be with us and care for us. He umm

- - he was hurt throughout his Iife. You know,

where I had an older sister that died of leukemia.

And when she died, Dad said that he would never

love another one of his children again. So I was

never able to experience this love.

Theme music up then under

CHASE: Turning Point . . worth a second thought . .

from the Seventh-day Adventist Church.

Theme music up then out 
TURNING POINT

Week 5

Spot 3

Theme music up then under and out

CHASE : Turning Point . . sixty seconds of contrast. INTERVIEWEE: You know, if my parents didn't have time... someone else would. That's why I really believe that I wanted to be with people that lived in communal-type living. It seemed as if everybody loved each other and cared for each other. . . which I'd never experienced before. But yet, it was a very selfish kind of love. It's what I can get, rather than what I can give. I believe that it wasn't until I accepted Christ was I able to love people. Because Christian people, if they really love Jesus Christ, they're able to share that love. You can see it. You can feel it around you. They ah, . . there's a special glow in their life and in their heart. . . that Christ has... because God is love.

Theme music up then under

CHASE :

Turning Point. . worth a second thought...

from the Seventh-day Adventist Church.

Theme. music up then out 
TURNING POINT

Week 5

Spot 4

Theme music up then under and out

CHASE :

Turning Point . . sixty seconds of contrast.

INTERVIEWEE: $\quad$ Both of my brothers have been baptized and have joined the church. They're fine Christians. They have helped my parents. My parents are taking Bible studies right now.

CHASE: There must be something to this Christian thing after all. What makes it so attractive? Why is it so great?

INTERVIEWEE: A new Iife . . a new experience, After surrendering my will, and giving... having my desires changed, and giving my life to Christ, I've come to know Christ. . come to know God and His Holy Spirit through studying His Word and through praying for the Spriit. . which has given me a peace and joy which passes all understanding. I have never experienced this before.

Theme music up then under

CHASE : Turning Point . . worth a second thought... from the Seventh-day Adventist Church.

Theme music up then out 
TURNING POINT

Week 5

Spot 5

Theme music up then under and out

CHASE : Turning Point . . sixty seconds of contrast.

INTERVIEWEE: $\quad$ My parents were always the kind of people that kind of pushed you to grow up. There's not time now to play. There's not time now for this or that. You've gotta hurry up. You've gotta get through school. You've gotta get this done. But to be a child is to take time out. . to take time to enjoy things. And children just enjoy Iife. And I think that's why God said, Come unto Me as a child, Because children share love. They don't have reasons why they do it. They do it because that's what they do. And that's how God is. He does it because that's what He thinks you need. That's what's best for you.

Theme music up then under

CHASE : Turning Point . . worth a second thought . . from the Seventh-day Adventist Church.

Theme music up then out 
TURNING POINT

Week 6

Spot 1

Theme music up then under and out

CHASE :

Turning Point . . sixty seconds of contrast.

INTERVIEWEE: I was just coming in from my work, and my husband said, I've got this conviction. I had this . . had this experience. . this religious experience. He says, I was sitting in this chair over here in the living room. And I was listening to this record. George Harrison was crying out, "My Sweet Lord, I really want to know you." He says, And all of a sudden, he said, the room just illuminated. And he says, And my heart was aching. And I knew I -. I had to find something. And he says, And tears came to my eyes, and I don't cry. And I thought, Wow! You know, this isn't like you. Tell me more. He says, I know. He says, you sit in the chair. He says, And I'll turn the record on . . and we'1l see if it happens again. And the next thing we knew, we were both down on our knees, crying. And crying out to the Lord to come to us. And He did!

Theme music up then under CHASE : Turning Point . . worth a second thought . . from the Seventh-day Adventist Church.

Theme music up then out. 
TURNING POINT

Week 6

Spot 2

Theme music up then under and out

CHASE : Turning Point. . sixty seconds of contrast. INTERVIEWEE: They wanted to share the Bible. And Joe said, Nope. That's not for me. He says, I don't want to have anything to do with the Bible. I know there is no truth in it. And, having never read the Bible, he realized he wasn't making any sense. And the people said, Well, do you have any questions? And Joe would ask the questions. And they said, Well, let's see what the Bible says. And they turned to the Bible and they read Scripture to us. And we said, That's right! That's the Truth! That... that just put peace in our hearts. That made us feel so good.

Theme music up then under

CHASE :

Turning Point . . worth a second thought. . . from the Seventh-day Adventist Church.

Theme music up then out 
TURNING POINT

Week 6

Spot 3

Theme music up then under and out

CHASE : Turning Point . . sixty seconds of contrast.

INTERVIEWEE: We had a very serious heart-to-heart talk that night. She pointed out to me what my life had been like. . . before I'd even come into contact with anything concerning religion. And she asked me if I wanted my life to stay that way. And I wasn't happy. And I knew I didn't want it to stay that way. And it was that night that I went and gave my life to Christ... in my dorm room. I found a peace and a real joy instantly . . as soon as I said . . said, Lord, here's my life. I'm tired of - . of this hassle, you know. I want to live a life in accordance with Your Word. I want to have that peace of mind and that joy that. . that only You can give.

Theme music up then under

CHASE: Turning Point . . worth a second thought... from the Seventh-day Adventist Church.

Theme music up and out 
TURNING POINT

Week 6

Spot 4

Theme music up then under and out

CHASE :

Turning Point. . sixty seconds of contrast.

INTERVIEWEE: My grandfather died when I was, oh, about 13 or 14

- . so I never really had a grandfather image.

And ah, I was engaged to a guy. . . that, ah, had

a beautiful grandfather. Oh, this man is just

tremendous. And we'd go over and visit him. And

I wasn't really used to being around old people.

And I always felt like, I really couldn't say much.

I really couldn't get excited, or, or couldn't

laugh a lot, because maybe something would happen

to them. And I was really afraid of old people.

And this man changed my whole idea. My whole out-

look. He ah... he lives by himself. And has a

small garden. And he loves Jesus Christ.

Theme music up then under

CHASE : Turning Point . . worth a second thought . .

from the Seventh-day Adventist Church.

Theme music up and out 
TURNING POINT

Week 6

Spot 5

Theme music up then under and out

CHASE :

Turning Point . . sixty seconds of contrast.

INTERVIEWEE: We weren't going to go... but something was telling us, Go-go-go! And that day we went to church. And when we walked into church, the feeling just filled us.. . this love that radiated in the sanctuary . . just filled our hearts. Now, mind you, we went to church, ah, exactly like we were. We didn't clean ourselves up. I had hair down to my waist . - and everything that went with it. Joe had his blue jeans and his sandals . . . and his shirts . . and we just went in . . as hippies. And these people loved us anyways. And we were just. . ah, we felt soooo good there! And they said, Why don't you come home and we'11 have a nice mea1.

Theme music up then under

CHASE : Turning Point.. worth a second thought . . from the Seventh-day Adventist Church.

Theme music up and out 
TURNING POINT

Week 7

Spot 1

Theme music up then under and out

CHASE :

Turning Point. . sixty seconds of contrast.

INTERVIEWEE: There was a time in my life where I conducted my affairs with people of . . of sharing, what's in it for me. And ah.. we can be partners. And when I found Christ, I found that He's fulfilled something in my life. . and I needed to pass that on . . to others. This was an urgent message. Now, I could see the mistakes I'd made, and I could see the mistakes other people were making. And I felt a desire--and I think it only came from God, because nothing inside me ever before motivated me to warn somebody of an impending trouble if they took a course of direction that I had taken.

Theme music up then under CHASE : Turning Point . . worth a second thought . . from the Seventh-day Adventist Church.

Theme music up and out 
TURNING POINT

Week 7

Spot 2

Theme music up then under and out

CHASE :

Turning Point.. sixty seconds of contrast.

INTERVIEWEE: For me, the knowledge of God is existential. It is totally, deeply in my heart. It is not an opinion. It's not an intellectual conviction. It is not the result of logical conclusions. But it is a dramatic experience by God . . . by which He made my heart . . changed it into a ball of fire. . . so that I could not sleep the whole night. And this is the light in my back, that I can fall back on. . . that when I have questions or doubts... I look back how God changed me.

Theme music up then under

CHASE : Turning Point.. . worth a second thought... from the Seventh-day Adventist Church.

Theme music up and out 
TURNING POINT

Week 7

Spot 3

Theme music up then under and out

CHASE :

INTERVIEWEE :
Turning Point . . sixty' seconds of contrast.

I was rescued by my sister. And after I get through over this, I was wondering what happens to my life from this time. I want to know more why it is that I have stayed so long on the bottom of the water . . and they have saved my 1ife. But as time goes on . . I wanted to find out, because my mother always told about this Man they call Jesus Christ. And I wanted to find out for myself. I found out--by studying the Scriptures--as time goes on . . I found out that Jesus Christ had changed my life completely.

Theme music up then under

CHASE :

Turning Point.. . worth a second thought... from the Seventh-day Adventist Church.

Theme music up and out 
TURNING POINT

Week 7

Spot 4

Theme music up then under and out

CHASE:

Turning Point . . sixty seconds of contrast.

INTERVIEWEE: After I found God, I realized that I could have a relationship on a one-to-one basis with my husband better. And I want to tell some of you girls that, you know, as we were wandering in our life before as freaks, it was always this love-love-love love your fellow man. You know, do your own thing. I'm telling you that I didn't know what love was until God entered me. I thought . . what I thought was love was being selfish. I was trying to get something for myse1f. I was trying to obtain a feeling and a comfort. Now . . I want to comfort somebody else.

Theme music up then under

CHASE :

Turning Point. . worth a second thought...

from the Seventh-day Adventist Church.

Theme music up and out 
TURNING POINT

Week 7

Spot 5

Theme music up then under and out

CHASE :

Turning Point. . sixty seconds of contrast.

INTERVIEWEE: I was very burdened about my father who has been an alcoholic for many, many years. And I thought, How can God reach him? How can He work through this alcoholism? Well, we prayed for my dad... and we had about fourteen other people praying for my father. And it wasn't but a month afterwards, I spoke with him. And for the first time, he didn't sound inebriated. He sounded like his head was kinda clear. And then about a week later, we received a letter from my dad. And he said that he had gone to church . . and he loved it. And he wasn't drinking anymore. And he says, And you know what? He says, I think I'm gonna stop smoking. And I thought, Praise God!. Al1 this-and what did I do? We prayed about it!

Theme music up then under

CHASE: Turning Point . . worth a second thought... from the Seventh-day Adventist Church.

Theme music up and out 
TURNING POINT

Week 8

Spot 1

Theme music up then under and out

CHASE: Turning Point . - sixty seconds of contrast.

INTERVIEWEE: The plane hit some air pockets. And ah, I felt

a little queezy .. . and my ears started popping.

People weren't quite at ease. And they were

wondering what was happening. And people were

dying their cigarettes out. And ah, I felt a little

turbulence. Of course, when you don't know at all

what is happening. . there's fear there. And

.. I started praying . . and asking God to help

me. And then I realized, I know where I'm going

when I die. I know there is a place for me. But

what about this fellow in the uniform sitting across

from me? What about this man over here playing

cards? What about this lady reading the magazine?

And I just had an ache in my heart. I said, I've

got to tell them.. about Jesus. And that there

is a place called Heaven.

Theme music up then under

CHASE :

Turning Point. . worth a second thought...

from the Seventh-day Adventist Church.

Theme music up and out 
TURNING POINT

Week 8

Spot 2

Theme music up then under and out

CHASE: Turning Point . . sixty seconds of contrast.

INTERVIEWEE: I would hate to think what my life would have turned out like had I continued on my same course. I was headed probably for self-destruction . . eventually. I hadn't gotten into drugs yet. . . but the drinking was, ah, was there. And I just wasn't happy. You just have such an emptiness inside you. And I think it finally comes to a head just before you hit the rock of Jesus Christ. When you decide to come to the Lord, you really don't know what to say to Him. Ah, I was very poor at praying. I - . I didn't know what to say to the Lord. But I knew I wanted forgiveness . . for these things that I had done. I think the Lord--even though you may not know how to really talk to Him--He helps you.

Theme music up then under CHASE : Turning Point . . worth a second thought... from the Seventh-day Adventist Church.

Theme music up and out 
TURNING POINT

Week 8

Spot 3

Theme music up then under and out

CHASE: Turning Point . . sixty seconds of contrast.

INTERVIEWEE: I work with people who are physically and psychologically handicapped. One lady in particular - . she seemed to be the most problematic one that I dealt with every day. Ah, she jumped out of the bus. And I saw her actually heading right out in the front of on-coming traffic. I jumped out of the van as fast as I could. And grabbed her. And I began telling her that, God'loves you. You are not alone in the world. God loves you and cares for you. I know because he changed my 1ife. And I said, Specifically, He's changed my life and used me as an instrument today to drive this bus. To grab you from in front of that car. . because He has a purpose for your life. You're not alone.

Theme music up then under

CHASE: Turning Point . - worth a second thought... from the Seventh-day Adventist Church.

Theme music up and out 
TURNING POINT

Week 8

Spot 4

Theme music up then under and out

CHASE :

Turning Point. . sixty seconds of contrast.

INTERVIEWEE: I'm not engaged to the guy that this is his origin-

al gampa, but he's my grampa now. You know, he told me, he'd adopt me. He'll tell me the difference in dress.. . the difference in cers.. . how cars came about.. the first car they were ever in -. trains.. he tells me everything. And, grandparents a lot of times don't say a lot of things. They think, Well, no they don't really care. And it's amazing what young people wanta hear from their grandfathers . . and grandparents. And.. . when I go over to visit him now. . he'll show me flowers in the garden that have grown. And share epxeriences with me. And it's really taught me to love and appreciate what older--what, you know, we would call aged people-have to share. . because they've experienced so much in 1ife.

Theme music up then under

CHASE : Turning Point . . worth a second thought . . from the Seventh-day Adventist Church.

Theme music up and out 
TURNIING POINT

Week 8

Spot 5

Theme music up then under and out

CHASE:

Turning Point . . sixty seconds of contrast.

INTERVIEWEE: I was really afraid. When I walked in there, the small children were all around . . boys hitting their heads against walls... blood... papers torn up . . just, children not being able to control themselves. But I thought, Well, I said I'd do it. I better do it. I got a young boy named Brent. And he was four-and-a-half at the time. And Brent couldn't talk. Brent continually pounded his head against the wa11. I ... I couldn't really relate to him. I tried to love him. But he wouldn't accept the love that I had. And it made me realize that I didn't really have love. I had a selfish love. I loved people for what they could do for me.. . not what I could do for them.

Theme music up then under CHASE : Turning Point . . worth a second thought... from the Seventh-day Adventist Church.

Theme music up and out 
TURNING POINT

Week 9

Spot 1

Theme music up then under and out

CHASE :

INTERVIEWEE :
Turning Point . . sixty seconds of contrast.

I got out of the hospital a week after the accident. And they told us they were going to fly my Daddy to Loma Linda within two days. But two days later, they told me that he was dead. My first thought was, Okay, God's my Father now. Because only God has enough love to fill the gap. God has become much closer to me. Because I appreciate nature. I appreciate things that God has made for me... the same way that I appreciated the doll house that my Daddy made for me. God is more than just a Father to me. He's my closest Friend. He is what I need.

Theme music up then under

CHASE : Turning Point . . worth a second thought. . from the Seventh-day Adventist Church.

Theme music up and out 
TURNING POINT

Week 9

Spot 2

Theme music up then under and out

CHASE:

Turning Point. . sixty seconds of contrast.

INTERVIEWEE: There's nothing I could do for you within sixty seconds except that you make a choice of your own. Al1 I can tell you is... is God loves you. If you want to, it will take time. You can find a better way. I'm offering it to you as best $I$ can. It will take time. You can't do it in sixty seconds. But make a commitment. Just make a choice that you will at least try. You've come this far in your decision . . look a little bit further. That's all I can offer to you. I can't do it in sixty seconds give you the whole explanation. Only thing I want to say to you is that right now He's changed my life, and sent me here to try to talk to you. Because He cares that much for you. He is interested in you. He has a good plan for your life.

Theme music up then under CHASE : Turning Point. . worth a second thought... from the Seventh-day Adventist Church.

Theme music up and out 
TURNING POINT

Week 9

Spot 3

Theme music up then under and out

CHASE :

Turning Point. . sixty seconds of contrast.

INTERVIEWEE: And to see Brent, for the first time to be able

to say, "My name is Brent, you name's Carol." Tears

came to my eyes. I just.. . "My name is Brent!"

and .. . we take these things for granted. That

we're able to write our names.. we're able to

say our names. We're able to walk. But what about

these children that can't walk? What about these

people that can't see? Or can't hear? We take

these things for granted. And with working with

him, I realize so much about God. Because God

gives all. God loves, and doesn't expect anything

in return. It's not a selfish love.

Theme music up then under

CHASE: Turning Point . . worth a second thought...

from the Seventh-day Adventist Church.

Theme music up and out 
TURNING POINT

Week 9

Spot 4

Theme music up then under and out

CHASE: Turning Point.. - sixty seconds of contrast.

INTERVIEWEE: Like my husband said, You can look above all this

materialism. You can see brightness here, and

flowers and beauty. You can love one another. And, hey listen, maybe . . did your girl friend leave

you? Your wife? Ah, we don't know what's wrong

with you. How can we help you? No matter what it

is. You're looking for somebody to love you. And

there's Somebody up there that just loves you so

much that He doesn't want to see you die. He

doesn't want to see you go... 'cause He's got

something in mind for you to do to help the next guy

down the bridge that's gonna jump off. Wouldn't you

like to save somebody else's life... instead of

killing yours? Wouldn't you like to have the

experience of . . of helping your fellow man?

It's just. . it's really . . you've got to

come and you've got to let us share with you what

Christ has done for us . . and see how our family

has changed.

Theme music up then under

CHASE :

Turning Point. . worth a seocnd thought...

from the Seventh-day Adventist Church.

Theme music up and out 
TURNING POINT

Week 9

Spot 5

Theme music up then under and out

CHASE :

Turning Point . . sixty seconds of contrast.

INTERVIEWEE: I had had some trouble with my knee. I was in an

accident. And had the interior of my knee just

demolished. And when I came to work on this floor,

I found this man--his name was Bil1--who had the

same problem. Both legs were totally stiff. And I

began working with Bill. I'd go in and we'd work

on stretching those legs. And gradually, bit-by-bit,

we got them to move. And the day finally came when

we took him out of his chair and put a restraint on

him. And began walking him. The turning point

came, I think, when I realized that I'd helped him--

that I'd given part of myself to him. And he'd

given part of himself to me. And together, we'd

both grown.

Theme music up then under

CHASE: Turning Point . . worth a second thought...

from the Seventh-day Adventist Church.

Theme music up and out 
TURNING POINT

Week 10

Spot 1

Theme music up then under and out

CHASE :

Turning Point. . sixty seconds of contrast.

INTERVIEWEE: I do not work, because I feel that my place is in

the home. When I worked, I saw it fall apart. It's

not materialistic things that make us happy. I

thought that was the way it was, too. I . . my.

husband and I never had very much money. And so

when I worked, we were able to buy. things we'd never

had before. And I thought, Boy, this is gonna make

us happy. I'd buy clothes for the children. .

toys for them I never was able to get. I'd bring

it home to them . . . and they didn't even appreci-

ate it. And I thought, Well I thought they'd really

like it. I thought this would really make them

happy. But what they really needed was my love.

And I didn't have time for that. I was too busy

working. But I had time to go down and buy things

for them. But what they really needed was love.

Theme music up then under

CHASE: Turning Point . . worth a second thought . .

from the Seventh-day Adventist Church.

Theme music up and out 
TURNING POINT

Week 10

Spot 2

Theme music up then under and out

CHASE :

Turning Point.. sixty seconds of contrast.

INTERVIEWEE: I was working in a rest home when the turning

point happened for me. It involved one of the

patients, whose legs were totally stiff. Eventually, we not only got the leg to bend again, but... in working with him.. . where before he'd been very much out of touch with reality . . we got him back in contact with reality. The only thing I found that's really given me some satisfaction is in this reaching out to another person. Ah . . . and I think. . you know, they don't have to be old and twisted, or, you know, legs that don't work in order to need help, you know. It's the person to the left or the right of you. It doesn't matter if they're 18 , or 30 , or 84 . Or what color they are - . or what religion they are.

Theme music up then under CHASE : Turning Point . . worth a second thought. . from the Seventh-day Adventist Church.

Theme music up and out 
TURNING POINT

Week 10

Spot 3

Theme music up then under and out

CHASE :

Turning Point . . sixty seconds of contrast.

INTERVIEWEE: I always felt that just to accept the beliefs of the Bible, and to go on in my life was all that I needed . . and to go to church. But I found out that my life was empty that way. And, with my own children, I saw that it was not working. And that I'd have to really ask God to come into my life in a very personal way, in order to have the blessings of God in my home.. . and not just to be a nominal Christian, going to church every week, but having a personal experience with Christ. And fully giving my life over to Him . . each day . . and trying my hardest to live like He'd want me to.

Theme music up then under

CHASE : Turning Point. . worth a second thought... from the Seventh-day Adventist Church.

Theme music up and out 
TURNING POINT

Week 10

Spot 4

Theme music up then under and out

CHASE :

Turning Point . . sixty seconds of contrast.

INTERVIEWEE: I had troubles in relating to other people . . and to loving other people. I loved my family very much. But to love others. . that was outside my home. And I asked the Lord to help me . . not to have bitterness in my heart towards people. But to learn to love them for the first time. Not to want them for my own pride, my own security of having friends . . but to $100 k$ out to them.. . to look to them as somebody. I could love and to give. And I stepped out and asked the Lord to help me. And I started meeting people. I started loving people - . for the first time in my life. And really enjoy life.

Theme music up then under

CHASE : Turning Point . . worth a second thought... from the Seventh-day Adventist Church.

Theme music up and out 
TURNING POINT

Week 10

Spot 5

Theme music up then under and out

CHASE : Turning Point . . sixty seconds of contrast.

INTERVIEWEE: That afternoon as the children came hom from school I still felt the bitterness in my heart. And my gir1--that I had the problem with--was wanting help on the, on her sewing. We11, the more she asked, the more irritated I got. And I knew that I was going to say something to hurt her. I said, Lord, I'm just going to go and talk to You about it. And would you please give me love for my girl... and give me peace. .. and thank You very much for answering my prayer. And I got up. Went into where my girl was. My heart was just filled with love and peace--that I did not have before. And my children said, Mommy, what's happened? And they said, We were feeling kind of uncomfortable around you. But you seem to be so happy now.

Theme music up then under.

CHASE: Turning Point . . worth a second thought . . from the Seventh-day Adventist Church.

Theme music up and out 
TURNING POINT

Week 11

Spot 1

Theme music up then under and out

CHASE :

Turning Point . . sixty seconds of contrast.

INTERVIEWEE: Wel1, I got in some scrapes this sumer and . .

this summer just wasn't turning out right.' I was

really into a lot of different problems. And it

finally really culminated in August when $I$ was in a

construction accident. I woke up one morning, and

I just didn't have any reason to keep living. It

was just a nice sunny morning in September, and it

seemed like life ended at age twenty. And it was

when I started working with these people in this

nursing home that I realized just how much I had.

That I was young, that I was healthy. And that, I

had, you know, so many years ahead of me in which

to really make some kind of contribution. And

then I'd be in the same position they were. And

that I really had to get it together... and get

going on it.

Theme music up then under

CHASE: Turning Point . - worth a second thought . .

from the Seventh-day Adventist Church.

Theme music up and out 
TURNING POINT

Week 11

Spot 2

Theme music up then under and out

CHASE:

Turning Point.. . sixty seconds of contrast.

INTERVIEWEE: We were in a financial problem because my husband wanted to go back to school. And I knew that something had to happen. And he couldn't work. So I worked. And that's when I noticed many problems coming into our home. My husband and I grew very distant. My children and I grew very distant. And this really killed me inside. . because I've always needed love in our home. And I saw there was none. We had money. But we didn't have love. And I knew only God could give me that 1ove. I knew I had to turn to Somebody much greater than me. I was, like you say, at the end of my rope. And so, this is when I really started praying. And God answered those prayers.

Theme music up and under

CHASE: Turning Point.. worth a second thought. . from the Seventh-day Adventist Church.

Theme music up and out 
TURNING POINT

Week 11

Spot 3

Theme music up then under and out

CHASE:

Turning Point . . sixty seconds of contrast.

INTERVIEWEE: I was bitter towards some people... for how they

had treated me. And I... I would go to church

and I would come home crying, because I felt so very

lonely inside. And I asked the Lord if He would

just help me to be able to go to church and to love

people.. for what they were.. and not wanting

anything from them. But just loving them. And He

give me that love. And I said, Lord, I know I'm

not doing anything for ycu, just have somebody ask

me. And I' 11 be more than happy to do it, in any

department in the church. And that was the answer

to some of, what, quite a bit of my bitterness...

was to become involved.

Theme music up and under

CHASE : . Turning Point . . worth a second thought . .

from the Seventh-day Adventist Church.

Theme music up and out 
TURNING POINT

Week 11

Spot 4

Theme music up then under and out

CHASE :

Turning Point. . sixty seconds of contrast.

INTERVIEWEE: ' I really started living it up. You know, drinking, and you-name-it, you know, I will do it. But one time I had a bad experience as a result of things I was doing. And I really started questioning my own lifestyle. I got on my knees. I really prayed. I said, Lord, I realize I have done a lot of things which You don't approve of. But at this point, I really want to turn my life (over) to You - . to do whatever you want me to do. I seemed to have been changed completely. My outlook on life. . Christ became very real to me. You know, it was no longer Somebody I just looked at, you know, from a distance. He became a part, you know - . He . . I could feel Him inside me, you know. It was something I really couldn't explain. But, once I started reading the Bible, everything started making sense for a change, you know.

Theme music up and under

CHASE : Turning Point.. . worth a second thought . . from the Seventh-day Adventist Church.

Theme music up and out 
TURNING POINT

Week 11

Spot 5

Theme music up then under and out

CHASE:

Turning Point... sixty seconds of contrast.

INTERVIEWEE: My little boy, Jeffrey, loves animals very much.

So, he wanted this little puppy and we had gotten

it for him. And this winter it got run over. So

I went in and talked to him, and I said, Jeffrey,

this is something very bad that's happened, because

we live on this kind of earth. You just wait, and

you just pray about it. Something beautiful's going

to happen. And then one day, one of our neighbors

asked us if we'd like to have a little dog. And it

was the kind of a dog that you just don't get very

often. And so Jeffrey says, Mother, . . (almost

every day). . Mother I thank God for this dog.

He truly answered my prayer. All I needed to do

was trust in Him. And when I did, He brought me

what I really wanted.

Theme music up then under

CHASE :

Turning Point . . worth a second thought . .

from the Seventh-day Adventist Church.

Theme music up and out 
TURNING POINT

Week 12

Spot 1

Theme music up then under and out

CHASE : Turning Point . - sixty seconds of contrast.

INTERVIEWEE: I found out that I was going to go into the hospital, with a thyroid operation. And I don't know about anybody else but, when I know that my throat is going to get cut, it scares me more than anything else. And the Lord was very, very close ... because He sent a lady right next to me that was the most beautiful Christian I had ever met in my life, and never have since. She had such faith in God . . that I'd never seen anybody have. She was going into a very serious surgery. And yet, she was peaceful, happy, and calm . . and had such a close walk with the Lord that when you were with her, you didn't feel scared at all. And through her presence I was able to go through the surgery without being scared.

Theme music up then under CHASE : Turning Point . . worth a second thought. . from the Seventh-day Adventist Church.

Theme music up and out 
TURNING POINT

Week 12

Spot 2

Theme music up then under and out

CHASE :

Turning Point . . sixty seconds of contrast.

INTERVIEWEE: I had broken up with my girlfriend, who was very

close to me. I missed her. She missed me. So we

kept writing... to one another. And after

awhile, I wrote to her and said, Listen, ah, I say,

you know, if you want to come back, I say, you

know, we can live together. And if things work out:

fine, you know, and so on. And she wrote me back,

and she said, We11, you know, I have to do some

explaining. And at that time, she told me that she

was living with another boyfriend prior to meeting

me, and so on. And at that time, of course, being

so close to her, I really started questioning, I

say, Something is wrong with my lifestyle. And $I$,

ah, I, I was really honest wiht muself. And

realized that, you know, I was just facing the

consequences of my own actions. And I just said,

Lord, I, I know I have been doing something wrong.

For some reason, I just knew I had no other place

to turn but to God.

Theme music up then under

CHASE :

Turning Point . . worth a second thought. .

from the Seventh-day Adventist Church.

Theme music up and out 
TURNING POINT

Week 12

Spot 3

Theme music up and then under and out

CHASE :

Turning Point . . sixty seconds of contrast.

INTERVIEWEE: $\quad$ For years, my life in religion never worked. And

I couldn't figure it out. And so I was scared of

God for years. And I never, ever got too close to

Him. And when I turried my heart over to the Lord,

a few years ago, I said, Lord, You know I . . I

see things around in nature. The things that grow,

like certain plants. They grow beautifully. You

know just what they need. But religion has never

been . . has never satisfied me. And I know

I've always looked at it in a wrong way. Please

show me the way it really works. Please help me.

And so I started reading. And the Lord, ah, the

words just came out of the Bible . . showing

Christ our righteousness.

Theme music up then under

CHASE : Turning Point . . worth a second thought . .

from the Seventh-day Adventist Church.

Theme music up and out 
TURNING POINT

Week 12

Spot 4

Theme music up then under and out

CHASE :

Turning Point . . sixty seconds of contrast.

INTERVIEWEE: I couldn't walk . . with only great effort. I was 40 years of age. And I only could see, What was the future going to hold, as a, seemed like an invalid. And I told God, that somehow if He could give me some direction. Because I knew that there was a God, but He was not real. And these were the words that I think changed my life, "Don't worry about anything; pray about everything. Because when you do this, you' 11 receive a peace that you you'11 not understand." When I came back home, I was rejoicing ah, in my God. . because I began to see, even though the pain was there, that peace had come to my heart.

Theme music up then under

CHASE: Turning Point . . worth a second thought. . from the Seventh-day Adventist Church.

Theme music up and out 
TURNING POINT

Week 12

Spot 5

Theme music up then under and out

CHASE :

Turning Point. . sixty seconds of contrast.

INTERVIEWEE : They said you must get some help.. . and you must go to Orthopedic. They tried to get appointments. They couldn't get any for a month . . unless I would go into the hospital that day. I had hurt enough that I didn't want to be hurt anymore. And so I said, I will wait the month. So I kept praising the Lord, and because I couldn't do anything else, I spent five to six hours a day just. reading--anything about God I could get my hands on. It was just like I was drinking a cup of cold water all the time. And when that month came, and I was to return to the doctor, my pain was gone.

Theme music up then under

CHASE: Turning Point . . worth a second thought . . from the Seventh-day Adventist Church.

Theme music up and out 
TURNING POINT

Week 13

Spot 1

Theme music up then under and out

CHASE: Turning Point . . sixty seconds of contrast.

INTERVIEWEE: I know what it feels like to want to end it all. I've had that thought many times. But it was when I heard God's voice in my mind, when I opened the Word and gave Him a chance to say something to me -. You've got to open that Word. You've got to say, Are you real, God? Challenge God, by saying reveal Yourself to me. You can't make yourself know God. He has to make you understand Him. But, you've gotta ask.

Theme music up then under

CHASE : Turning Point.. . worth a second thought... from the Seventh-day Adventist Church.

Theme music up and out 
TURNING POINT

Week 13

Spot 2

Theme music up then under and out

CHASE :

Turning Point. . sixty seconds of contrast.

INTERVIEWEE: I would go into the doctor's office.. I can

remember people telling me later, Joyce, we never

could speak to you, because we didn't know what

would happen. The doctors had told us, Don't. .

only the Head Nurse could speak to you, because

they were afraid that at any moment I would just,

I suppose, disintegrate. I didn't realize I was

that bad. But when I found the Lord, of course, I

saw the blackness, and I see the brightness, I see

the joy . . I saw the gentleness of Jesus. I

saw His kindness. I saw His Fatherliness. I saw

His friendliness . . His goodness . . His al1-

caring. And I know that's rea1. . because I've experienced it.

Theme music up then under

CHASE :

Turning Point . . worth a second thought. .

from the Seventh-day Adventist Church.

Theme music up and out 
TURNING POINT

Week 13

Spot 3

Theme music up then under and out

CHASE :

Turning Point. . sixty seconds of contrast.

INTERVIEWEE: When I was 18, I'd gone into the Navy, had become

immersed in the drug culture. When I got out, then

I got immersed in the hippie-type lifestyle. And

ah, I was searching for meaning . . in life.

Basically, who I am. Why am I here? Does anybody

really care . . about me? Well, the turning

point in my life was when I found a meaningful

relationship, connection with God . . that I

found out who He is... and that He had a

personal interest in me. And having realized that

it changed me.. . in my motivation to.. . to

reach out to Him.. . as I realized He had been

reaching out to me . . for so long . . before

I ever realized it.

Theme music up then under

CHASE :

Turning Point . . worth a second thought . .

from the Seventh-day Adventist Church.

Theme music up and out 
TURNING POINT

Week 13

Spot 4

Theme music up then under and out

CHASE :

Turning Point . . sixty seconds of contrast.

INTERVIEWEE: The more I studied, I became convinced that in three days, like it was taught, I could experience Nirvana - . if I totally renounced everything in the world. So that's what I did. I quit my job; I turned in my company car. I gave up everything that $I$ was connected with in the world. And I. . for three days I fasted and prayed and asked God to make Himself known to me. And ah, He did. He did. It wasn't satisfying until I found Christ, because I didn't have the connecting link to God.

Theme music up then under

CHASE : Turning Point. . worth a second thought. . from the Seventh-day Adventist Church.

Theme music up then out 
TURNING POINT

Week 13

Spot 5

Theme music up then under and out

CHASE:

Turning Point . . sixty seconds of contrast.

INTERVIEWEE: I came from a broken family, from where I wanted to look for something better. I was looking for meaning. The turning point in my life came when $I$ was 18 years of age. And someone gave me a book that explained the plan of God, the plan of salvation, the great love of God. And when I began to read that book, there was a spark discharged. My soul was touched. And God laid His hand on me. And I gave my heart to Christ. From that time on, everything became different. I wanted to be God's man.

Theme music up then under CHASE : Turning Point . . worth a second thought... from the Seventh-day Adventist Church.

Theme music up then out 


\section{SELECTED BIBLIOGRAPHY}

\section{Books}

Anderson, Roy Allan. The Shepherd-Evangelist. Washington, D.C.: Review \& Herald Pub. Assn., 1950.

Armstrong, Ben, and Sheldon, LaVey. Directory of Religious Broadcasting. Morristown, N.J.: National Religious Broadcasters, 1976.

Augsburger, David W. Communicating Good News. Newton, Kansas: Faith and Life Press, 1972.

Autrey, C. E. Basic Evangelism. Grand Rapids, Mich.: Zondervan Publishing House, 1959.

Bachman, John W. The Church in the World of Radio-Television. New York: Association Press, 1960.

Bede11, Clyde. How to Write Advertising that Sells. New York: McGraw-Hill Book Co., 1952.

Benson, Dennis C. Electric Evangelisin. Nashville, Tenn.: Abingdon Press, 1973.

Biederwolf, William E. Evangelism: Its Justification, Its Operation and Its Value. New York: Fleming H. Reve11 Co., 1921.

Brown, Fred. Secular Evangelism. Gateshead, Great Britain: Northumberland Press, 1970.

Butler, Philip. "Evangelism and the Media: A Theological Basis for Action." In Let the Earth Hear His Voice, pp. 526-32. Edited by J. D. Douglas. Minneapolis, Minn.: World Wide Publications, 1975.

- "Mass Communications Report." In Let the Earth Hear His Voice," pp. 1311-12. Edited by J. D. Douglas. Minneapolis, Minn.: World Wide Publications, 1975.

Chase, James E. Ten Tips on Taking to the Air: A Manual for Gospel Broadcasters. Washington, D.C.: General Conference of Seventh-day Adventists: Radio and Television Dept., 1961. (Mimeographed.) 
Chester, Giraud; Garrison, Garnet R.; and Willis, Edgar E. Television and Radio. 3rd ed. New York: Appleton-CenturyCrofts, 1963.

Craig, Floyd A. Christian Communicator's Handbook. Nashville, Tenn.: Broadman Press, 1969.

Cutlip, Scott M., and Center, Allen H. Effective Public Relations. 2nd ed. Englewood Cliffs, N.J.: Prentice-Hall, 1958.

Dinwiddie, Melville. Religion by Radio. London: George Allen and Unwin, 1968.

Douglas, J. D., ed. Let the Earth Hear His Voice. Minneapolis, Minn.: World Wide Publications, 1975.

E1lens, J. Harold. Models of Religious Broadcasting. Grand Rapids, Mich.: William B. Eerdmans Pub. Co., 1974.

Engel, James F., and Norton, H. Wilbert. What's Gone Wrong with the Harvest? Grand Rapids, Mich.: Zondervan Publishing House, 1975.

Fore, William F. Image and Impact: How Man Comes Through in the Mass Media. New York: Friendship Press, 1970.

Glass, Gene V., and Stanley, Julian C. Statistical Methods in Education and Psychology. Englewood Cliffs, N.J.: PrenticeHall, 1970 .

Hiebert, Ray Eldon; Ungurait, Donald F.; and Bohn, Thomas W. Mass Media: An Introduction to Modern Communication. New York: David McKay Co., 1974.

Hilliard, Robert L. Radio Broadcasting: An Introduction to the Sound Medium. New York: Hastings House, 1967.

Homrighausen, E. G. "Evangelism: Ministry of the Church." In Evangelism and Pastoral Psychology, pp. 17-22. Edited by Simon Doniger. Great Neck, N.Y.: Pastoral Psychology Press, n.d.

Iversen, J. Orville. So You're Going on the Air! Washington, D.C.: Review \& Herald Pub. Assn., 1969.

Jemison, T. House1. A Prophet among You. Moutain View, Calif.: Review \& Herald Pub. Assn., 1969.

Johrson, Joseph S., and Jones, Kenneth K. Modern Radio Station Practices. Belmont, Calif.: Wadsworth Pub. Co., 1972 .

Jones, Clarence W. Radio--The New Missionary. Chicago: Moody Press, 1949. 
Kraemer, Hendrik. The Communication of the Christian Faith. Philadelphia: The Westminster Press, 1956.

Kuiper, R. B. God-Centered Evangelism. Grand Rapids, Mich.: Baker Book House, 1961.

Lesly, Philip, ed. Lesly's Public Relations Handbook. Englewood Cliffs, N.J.: Prentice-Hall, 1971.

Marty, Martin E. The Improper Opinion. Philadelphia: Westminster Press, 1961 .

Merri11, John C., and Lowenstein, Ralph. Media, Messages, and Men. New York: David McKay Co., 1971.

Michigan Be11 Telephone Directory: Benton Harbor-St. Joseph Area 1976-77. Detroit, Mich.: Michigan Bell Telephone Co., issued october 1976.

Nida, Eugene A. Message and Mission: The Communication of the Christian Faith. New York: Harper \& Row, 1960.

North American Radio Commission and the Ministerial Association of Seventh-day Adventists. Broadcasting the Advent Message. Washington, D.C.: Review \& Herald Pub. Assn., 1944.

Parker, Everett C.; Barry, David W.; and Smythe, Dallas W. The Television-Radio Audience and Religion. New York: Harper \& Bros., 1955 .

Peters, George W. Saturation Evangelism. Grand Rapids, Mich.: Zondervan Publishing House, 1970 .

Pentecost, Edward C. Reaching the Unreached: An Introductory Study on Developing an Overal1 Strategy for World Evangelism. South Pasedena, Calif.: William Carey Library, 1974.

Reagen, Michael V., and Cherton, Doris S., ed. The Challenge of Modern Church-Public Relations. Syracuse University: Publications in Continuing Education, 1973.

Redekop, Calvin. The Church Functions With Purpose. Scottdale, Penn.: Herald Press, 1967.

Schramn, Wilbur. Men, Messages, and Media. New York: Harper \& Row, 1973.

Scragg, Walter R. L. The Media, the Message, and Man. Nashville, Tenn.: Southern Pub. Assn., 1972.

Starlin, Glenn, and Sherriffs, Ronald. Speech Communication via Radio and Television. Dubuque, Iowa: Wm. C. Brown Co., 1971. 
Stoody, Ralph. A Handbook of Church Public Relations. New York: Abingdon Press, 1959.

Stott, John R. W. Christian Mission in the Modern World. Downers Grove, I11.: InterVarsity Press, 1975.

Taylor, Shirril W., ed. Radio Programming in Action: Realities and Opportunities. New York: Hastings House, 1967.

Tillich, Paul. "Communicating the Gospel." In Evangelism and Pastoral Psychology, pp. 9-16. Edited by Simon Doniger. Great Neck, N.Y.: Pastoral Psychology Press, 1956.

Webster's New Collegiate Dictionary. $1959 \mathrm{ed}$. S.v. "Broadcasting."

White, Ellen G. The Acts of the Apostles. Mountain View, Calif.: Pacific Press Pub. Assn., 1911.

- Christ's Object Lessons. Washington, D.C.: Review \& Herald Pub. Assn., 1941.

- The Desire of Ages. Mountin View, Calif.: Pacific Press Pub. Assn., 1940.

- Evangelism. Washington, D.C.: Review \& Herald Pub. Assn., 1946 .

- Gospel Workers. Washington, D.C.: Review \& Herald Pub. Assn., 1915 .

- Steps to Christ. Mountain View, Calif.: Pacific Press Press Pub. Assn., 1956.

- Testimonies to Ministers and Gospel Workers. Mountain View, Calif.: Pacific Press Pub. Assn., 1962.

Wilson, Ron. Multimedia Handbook. Elgin, I11.: David C. Cook Pub. Co. , $1 \overline{975 .}$

\section{Unpublished Materials}

Boone, Arthur Ivan. "The Influence of Voice Distinguishability on Source Credibility." Ph:D. thesis, Michigan State University, 1971 .

Chenhwang, Edward Yih-Min. "Thematic Content Analysis as an Approach to Prediction of Audience Receptivity of Religious Radio Programs, with a Demographic Analysis of Program Preference." Ph.D. dissertation, Michigan State University, 1974. 
Cowdin, Hugh Pendleton. "Development of Persuasive Messages Based on the Belief Patterns of the Audience, and the Effects of Authorities and Dogmatism on Change of Beliefs." Ph.D. thesis, University of Iowa, 1968.

Dick, D. Donald. "A Survey of Local Religious Radio Broadcasting in Los Angeles, California, with a Bibliography on Religious Broadcasting, 1920-1964." Ph.D. thesis, lichigan State University, 1965 .

Dietrich, John E. "The Relative Effectiveness of Two Modes of Radio Delivery in Influencing Attitudes." Ph.D. dissertation, University of Wisconsin, 1945.

Erickson, Elmer Julius. "A Critical Analysis of Three Types of Radio Listening." Ph.D. dissertation, University of Southern California, 1942.

Guli, Nancy Marion. "A Victory in Persuasion: A Descriptive Analysis of the Radio Campaign Conducted by Columbia University, in Association with the United States Public Health Service, for the Nationwide Syphilis Case-finding Drives of 1948-51." Ed.D. dissertation, Columbia University, 1968.

Handysides, D. J. Personal letter to Janes Chase, 19 October 1972.

Hardinge, Leslie. "An Examination of the Phijosophy of Persuasion in Pulpit Oratory Advocated by Ellen Gould White." M.A. thesis, Andrews University, 1950.

Highlander, John Palmer. "Audience Analyzer Measurements and Informational Effects of Speaker Variables in Radio Talks."" $\mathrm{Ph} . \mathrm{D}$. thesis, University of Wisconsin, 1953.

Lane, Jonathan P. "Smokers" Reactions to a Television Program about Lung Cancer: A Study of Dissonance." Ph.D. dissertation, Stanford University, 1960.

McCandless, Boyd Rowden. "A Study of Selected Factors Affecting Radio Listening Behavior." State University of Iowa, 1941.

Pierce, Merle Scheffe1. "Methods of Experimentation in Radio Research, and Correlates of Effective Radio Advertising." $\mathrm{Ph} . \mathrm{D}$. thesis, University of Wisconsin, 1958.

Ringe, Robert Charles. "An Analysis of Selected Personality and Behavioral Characteristics Which Affect Receptivity to Religious Broadcasting." Ph.D. dissertation, Ohio State University, 1969. 
Robinson, Haddon William. "A Study of the Audience for Religious Radio and Television Broadcasts in Seven Cities throughout the United States." Ph.D. thesis, University of Illinois, 1964.

Rue, James Joseph. "An Experimental Study of the Relative Effectiveness of Certain Types of Radio and Television Commercials." Ph.D. dissertation, University of Southern California, 1954 .

Solt, David Charles. "A Study of the Audience Profile for Religious Broadcasts in Onondaga County." Ph.D. dissertation, Syracuse University, 1971 .

\section{Periodicals}

Deal, Sylvia. "Credibility." Psychology Abstracts File, 1976.

Griffin, Emory. "The Role of Media in Changing Attitudes." Spectrum, Summer, 1976, P. 5 .

Kerjcie, Robert V., and Morgan, Daryl. "Determining Sample Size for Research Activities." Educational and Psychological Measurement 30 (Autumn 1970): 607-10.

Kuester, Theda. "Radio Program Helps Growth in Church." Review and Herajd, 26 August 1971, p. 19.

Levine, John M., and Valle, Ronald S. "The Convert as a Credible Communicator." Socia1 Behavior and Personality 3 (January 1975): 81-90.

McCroskey, James C., and Combs, Walter H. "The Effects of the Use of Analogy on Attitude Change and Source Credibility." Journal of Communication 19 (December 1969): 333-39.

Markham, David. "The Dimensions of Source Credibility of Television Newscasters." Journal of Communication 18 (March 1968): 57-64.

Montagno, Margaret, and Huck, Janet. "The Selling of Jesus." Newsweek, 28 February 1977, pp. 48-49.

Religious Broadcasting, April-May, 1975.

Tuppen, Christopher J. S. "Dimensions of Communicator Credibility: An Oblique Solution." Speech Monographs 41 (August 1974): 253-60. 
VITA

James David Chase is an ordained minister of the Seventh-day Adventist Church. Currently, he is Assistant Professor Religious Broadcasting at Andrews University, Berrien Springs, Michigan.

Born November 12, 1946 in Grand Island, Nebraska, Elder Chase attended John Nevins Andrews Elementary Schoo1, Takoma Academy, Sunnydale Academy, and Pacific Union College where, in 1969, he graduated with a B.A. in Theology. Three years later (1972), he received an M.Div. degree from Andrews University Theological Seminary. Since then, he has taken graduate coursework in broadcasting at the University of Washington and Michigan State University.

Before joining the faculty of Andrews University, Elder Chase pastored in the following cities in the Central California Conference: Bakersfield, Mountain View, San Luis Obispo, and Morro Bay. He was ordained to the gospel ministry of the Seventh-day Adventist Church at the Michigan Conference Campmeeting in July, 1975.

In addition to numerous daily radio programs produced as a part of his pastoral ministry, Elder Chase has produced a series of radio spots released by the General Conference of Seventh-day Adventists to radio stations throughout the United States.

He is a member of the Board of Directors of the Adventist Radio Network, and a member of the Board of Directors of WAUS, the Andrews University radio station. 